\title{
Volume 3, Number 1
}

\section{Hipatia Press}

www.hipatiapress.com

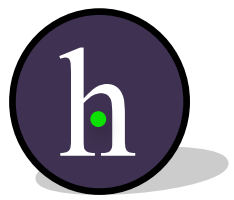

\section{Visual Pages}

Articles
Anell de Pedra. La Comella, 1976-2001. Rufino Mesa

Rufino Mesa -

Resistencia y Dolor. Tracey Emin:

La Belleza de lo Pecaminoso y la Fragilidad de lo Vulnerable

Fernando Sáez -

La Subjetividad y la Fantasía en la Creación Plástica: Sus

Procesos Psicológicos y Simbólicos en el Arte Infantil y

Primitivo

Belén León Río -

El Arte como Resistencia. La Ópera-Tango María de Buenos

Aires

Carlos L. Bosch -

Adventure Series de Tracey Moffatt y la TV Star

María V. Caro Cabrera

Reviews Mathias Goeritz. Recuerdos de España, 1940-1953

Alberto Castán Chocarro -

List of Reviewers - 
Instructions for authors, subscriptions and further details:

http://brac.hipatiapress.com

\section{Anell de Pedra. La Comella, 1976-2001. Rufino Mesa}

Rufino Mesa ${ }^{1}$

1) Artista y Doctor en Bellas Artes

Date of publication: February $3^{\text {rd }}, 2015$

Edition period: February 2015 - June 2015

To cite this article: Mesa, R. (2015). Anell de Pedra. La Comella, 19762001. Rufino Mesa. Barcelona, Research, Art, Creation, 3(1), 1-12. doi: 10.4471/brac.2015.01

To link this article: http://dx.doi.org/10.4471/brac.2015.01

\section{PLEASE SCROLL DOWN FOR ARTICLE}

The terms and conditions of use, except where otherwise noted, are related to the Open Journal System and to Creative Commons Attribution License (CCBY). The indication must be expressly stated when necessary. 


\section{Stone ring. La Comella, 1976- 2001. Rufino Mesa}

Rufino Mesa

Artist and Doctor of Fine Arts

\section{Abstract}

The day when the rocks, which form the Stone ring, were moved from Reus and installed in La Comella (Tarragona), the voice left and I deeply get to know the value of fatigue.

I could not talk then but I realized that each one of the stones had an identity and that since that moment all them together will form an idea: now it is the right moment to present the observation.... 


\section{Anillo de Piedra. La Comella, 1976-2001. Rufino Mesa}

Rufino Mesa

Artista y Doctor en Bellas Artes

\section{Resumen}

El día que desde Reus transportamos las rocas que forman el Círculo de piedra y que instalamos en La Comella (Tarragona), perdí la voz y conocí en esencia el valor de la fatiga.

En ese momento me fue imposible hablar, pero pensé que cada piedra tenía una identidad y que desde aquel instante todas ellas formarían una idea: creo que ahora es el momento oportuno para presentar la observación.... 


\section{Anell de pedra. La Comella, 1976-2001. Rufino Mesa}

Rufino Mesa

Artista i Doctor en Belles Arts

\section{Resum}

El dia que vam transportar des de Reus les roques que formen l'Anell de pedra i les vam instal·lar a La Comella (Tarragona), la veu em va marxar i vaig conèixer en profunditat el valor de la fatiga.

Llavors no podia parlar però vaig pensar que cada pedra tenia una identitat i des de llavors totes elles formarien una idea: ara penso que és el moment oportú per a presentar l'observació... 


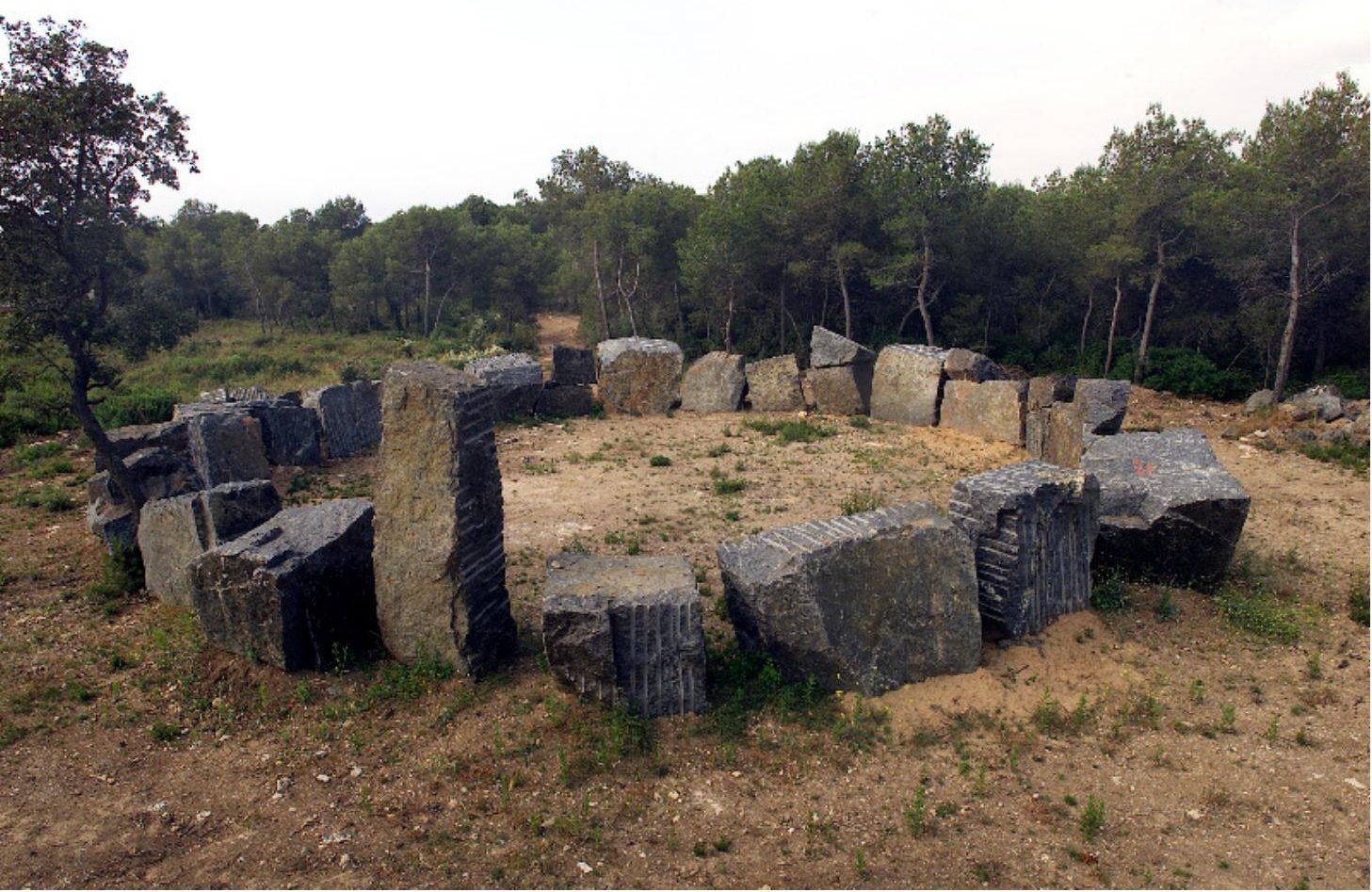

Figura 1. "Anell de pedra". La Comella, 1976-2001.

$17 \mathrm{~m}$. de diàmetre x 3,20 m. d'alçada. Granit negre de la ex. U. R. S. S.

(C) Rufino Mesa 


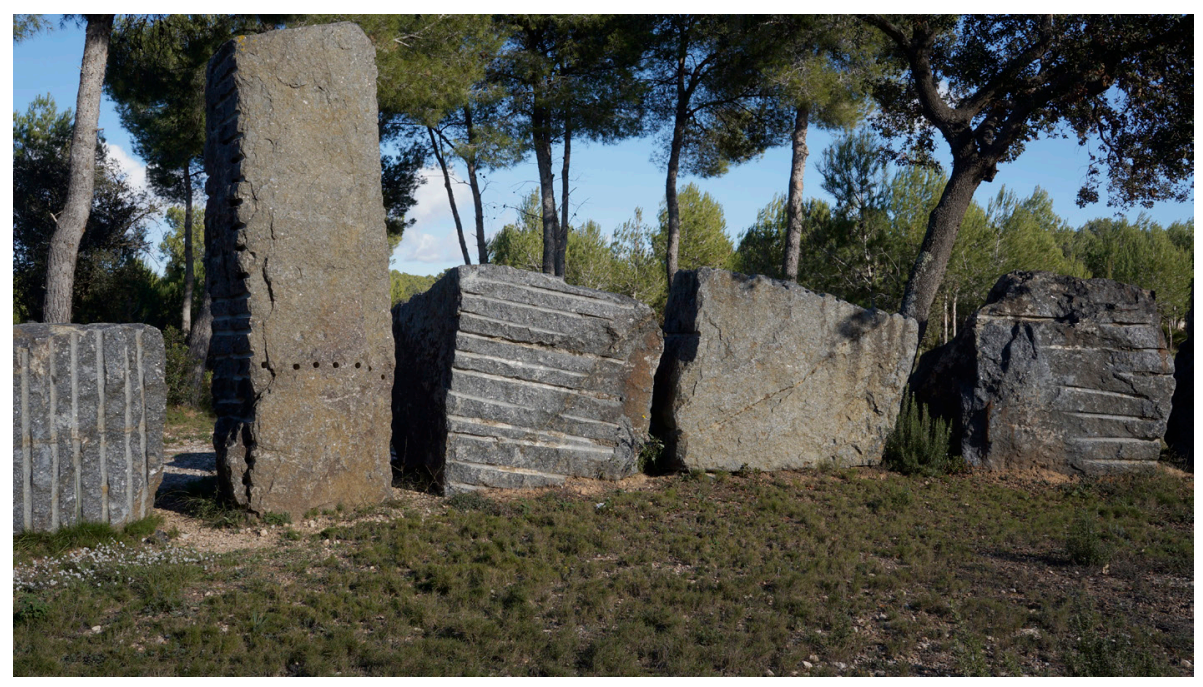

Figura 2. “Anell de pedra". La Comella, 1976-2001. (Detall). (C) Rufino Mesa 


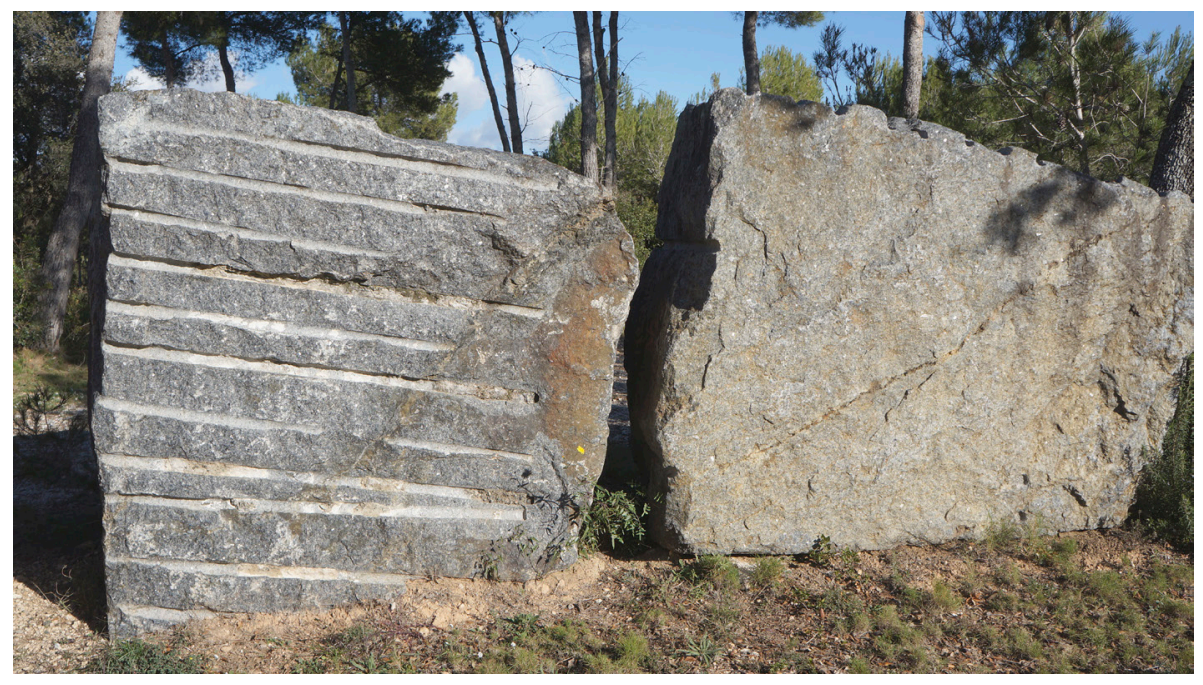

Figura 3. “Anell de pedra". La Comella, 1976-2001. (Detall). (C) Rufino Mesa 


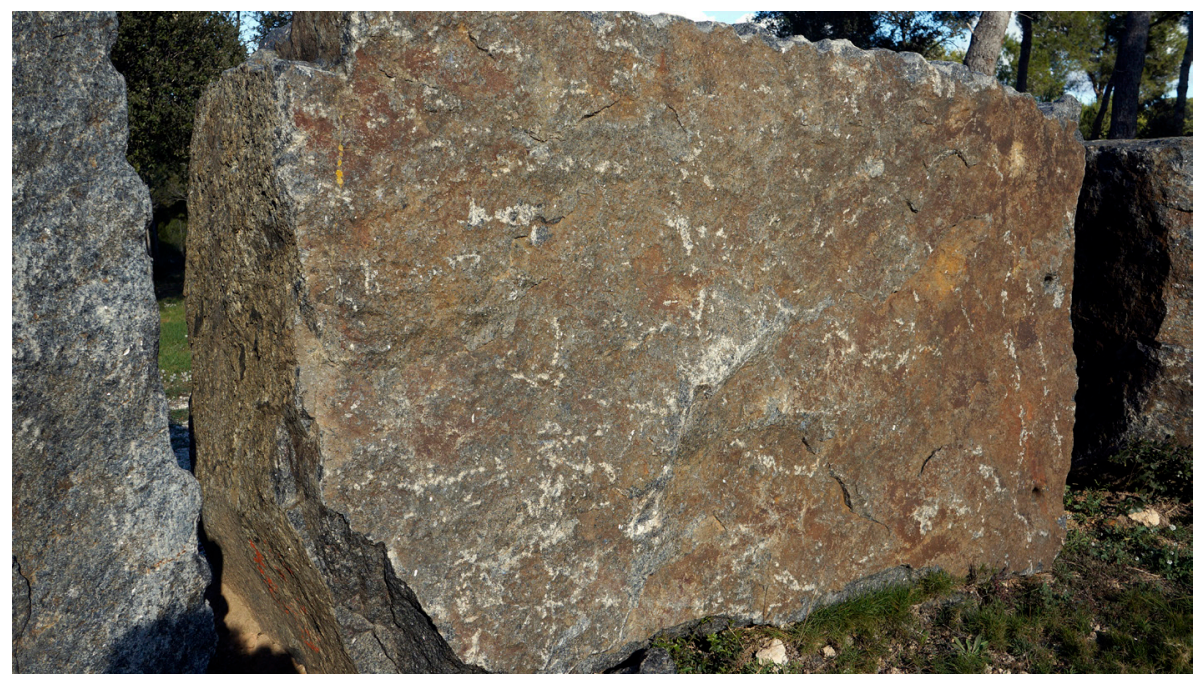

Figura 4. “Anell de pedra". La Comella, 1976-2001. (Detall). (C) Rufino Mesa 


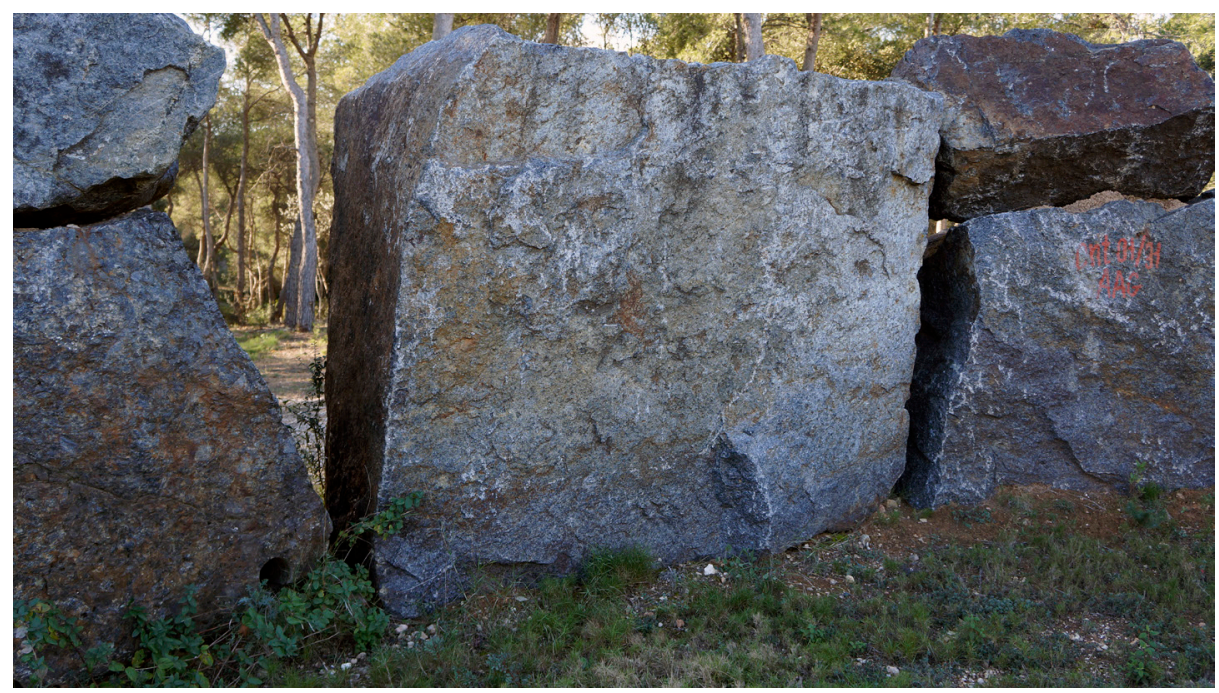

Figura 5. “Anell de pedra". La Comella, 1976-2001. (Detall). (C) Rufino Mesa 
$\mathbf{R}$

eplicant les construccions dels pastors de les muntanyes d'Urbasa, d'Andía, d'Aralar, el 1976 vaig iniciar un treball efímer, senzill i compromès: una aliança en forma d'anell. Era una idea aparentment sense gravetat, una acció per al consum personal, la moixaina del vent en la contemplació instantània, però per a mi va ser l'inici dels anells del pacte, un treball que posteriorment ocuparia part important de la meva vida. Amb un bastó gratava el terra i configurava un cercle que, seguidament, contemplava com si d'una aparició es tractés. Anells petits (no més de metre i mig, alguns de $70 \mathrm{~cm}$.) dibuixats amb herbes, terra, pedres, llaunes o directament a la sorra de la platja. Les incipients arquitectures eren d'expressió mínima i es presentaven com caixes obertes que s'emmirallaven amb el sol. No informaven de res especial a excepció de la màgia que es desprèn de l'estètica del cercle: posteriorment sí, la forma va adquirir un compromís remarcable.

A diferència del joc simbòlic que es va formular amb l'anell, els cercles de pedra d'Urbasa, d'Aralar i Andía eren de naturalesa diferent. Els cromlec dels pastors neolítics, no eren símbols d'un pacte, tampoc eren espais funeraris, eren construccions de pedres de funció desconeguda segons afirma Barandiarán. Presenten el seu espai intern orfe de funció concreta i el buit interior, el no res i la seva naturalesa enigmàtica, va ser la que va captivar Oteiza (1973) segons ell mateix em va dir. Ell deia que la valoració i contemplació quedava continguda dins del misteri, s'havia de mirar des de fora, al·legoria de l'estètica per l'estètica com passa en les obres de Richard Long.

Com he dit aquest no va ser el valor que jo cercava a les construccions circulars. Tot plegat vaig buscar la funció simbòlica del pacte, el compromís amb la natura i el treball posterior dirigit a fer d'una roca un jardí restaurat: la Comella. El cercle ha estat l'expressió d'una aliança amb la vida i la seva aplicació formal i conceptual ha quedat a les terres que envolten el meu taller. http://lacomella.org/

\section{El Lloc}

Com he dit el testimoni material de l'aliança ha quedat a la "Comella, Escultura i Natura” (CEN) És un bosc mediterrani de $78.000 \mathrm{~m} 2$, amb unes 120 obres que tracten diferents aspectes de l'experiència de viure. És un centre privat amb voluntat pública. Tot el conjunt (escultures, arranjament de la ma- 
sia i neteja del bosc), ha estat elaborat com "una obra" on la natura és l'eix i el motiu principal de la reflexió estètica. Amb el temps s'ha esdevingut en un parc d'escultures on queda explícita, clarament induïda, la reflexió sobre l'art i la vida. El treball és respectuós amb la història i manté un compromís amb la terra per crear un sistema sostenible. CEN és el resultat de 40 anys de recerques, un treball continuat que ha tingut la voluntat de viure l'art contemporani i la natura com una forma d'entregar-se i proporcionar sentit a la vida.

Aquí recordaré unes paraules de Arvol Looking Horse (1994), un indi Lacotà que reclamava la necessitat del pacte $\mathrm{i}$ un rostre reconciliador amb la natura, unes paraules que tenen avui tota la vigència.

Nos hallamos ahora en una etapa crítica de nuestro desarrollo espiritual, moral y tecnológico como naciones. Toda la vida se encuentra en un equilibrio precario. Hemos de recordar que todas las coses de la Madre Tierra poseen un espíritu y se hallan intrincadamente relacionadas. Ha comenzado a cumplirse la profecía lakota de recomponer el sagrado anillo de todas las naciones. En la antigua sabiduría de las naciones indígenas, podemos hallar el espíritu y el valor para enmendar y curar. (p. 36)

\section{Cercle i Concepte}

A l'època moderna la presència del cercle és virtual, la formen els electrons al voltant del nucli i són presències furtives, "mandales" meravellosos a l'espai interior de la matèria. És un escenari teòric on podem fer un ritual per a la pregària pagana $\mathrm{i}$ on podem ocultar la incertesa de la nostra acció espiritual. Allí es troba el principi de la bellesa i el santuari de la postmodernitat, el que presenta la física quàntica i demana una atenció espiritual renovada. Penso que, com en una roca mil·lenària, allí s'ha d'escriure una paraula, no amb neó com faria Joseph Kosuth, sinó amb el bategar del cor i el pols de la intenció. Aquest escenari és el mateix que fa milers d'anys s'havia intuït i presentat des de la visió poètica i religiosa $\mathrm{i}$ ara, en l'era del buit i les estratègies del simulacre és un material conceptual per fer l'obra. En el moment de la instrumentació del desig i la llibertat absoluta, quan les idees s'han esfondrat $i$ han quedat engolides sobre si mateixes, no queda altre camí que l'actitud resignada en aquest espai, la convicció en les idees que es depositen allí, o pot ser, en la direcció neuròtica de l'ocultació. 


\section{El Compromís}

Aquells cercles, els dels anys de la meva formació, eren presidits pels seus silencis, per la seva lluminositat i foscor. En aquell moment calia fer l'obra al marge del mercat i el glamur dels museus: confesso que vaig creure plenament en tot el discurs i vaig ser un alumne aplicat. Llavors érem joves, vivíem l'època conceptual i l'ètica del compromís: l'obra havia d'estar arrelada en la vida i la idea sempre havia de ser més important que la forma.

Aquells espais desocupats, aquelles àrees buides, em van captivar i van configurar l'inici de les ocultacions i la gran aventura de la meva vida. Treballar en la cara fosca de la realitat ha estat apassionant i m'ha proporcionat grans dosis de llibertat. En realitat les obres eren excuses per dir allò que volia dir i he de manifestar que així ho he fet. En aquells espais hipotètics trobava un fons caòtic d'infinites transformacions, un escenari que creixia en totes les direccions i captivava el pensament con una melodia: tot plegat era un camí per a expressar-me en llibertat. Era un oceà sense límits aparents on les idees suraven i naixien de manera incessant.

En "Palabra oscura" (obra unida conceptualment a l'anell i que recull el compromís personal envers la natura), vaig viure una experiència única. Per un instant allí s'exhibia sobre el fang l'objecte de la meva realitat mental. L'escultura està formada per sis caixes de bronze amb els documents testamentaris: boles de fang plenes de paraules que ara s'exposen a la Biblioteca Xavier Amorós de Reus.

Després de la feina feta, dels dubtes que he gestionat, penso que persistir en la presentació de les idees en aquest espai i fer-lo sense la complicitat i el reconeixement social és un suïcidi intel·lectual, una quimera que delata certa neurosi, però jo vaig estar treballant-hi 40 anys i encara aguanto el camí traçat amb la mateixa convicció.

\section{El Pacte}

L'espai de l'anell no eren territoris per les divinitats, eren llocs naturals on la creació material m'invitava a actuar en la seva pell lluminosa: acció per deixar en silenci el registre de la paraula i a la terra la intervenció restauradora, la carícia entregada a la natura. El pacte no és una idea peregrina i estic disposat a continuar per aquest camí carregat de futur encara que hagi de pagar un preu elevat. 
Els defectes que pot patir l'art que renuncia a la presentació formal s'han de tenir en compte. D'entrada pot allunyar-se de la realitat social i presentar-se com un compromís moral, una opció política o estètica ennuvolada i confosa. No crec però que aquest sigui el problema més greu que presento al llarg de la meva vida: com el silenci, les paraules ocultes també podem escoltar-les. La societat moderna ens ha arrencat la confiança en aquests valors mistèrics i crec que la forma de restaurar-los és, precisament, presentant l'absència del sentit. L'obra instal·lada en el lloc del sacrifici, a l'espai de la renuncia. Amagar la tenacitat de l'autor tot ocultant les idees, deixant l'ànima de l'obra secreta però pressentida i clandestina dins la Caixa que s'esborra al fons.

Rufino Mesa 29 de desembre de 2014

\section{Referencias}

Oteiza, J. (1973). Quosque tanden...! Estella. Verbo Divino. 44, 96.

Gran Jefe Seattle. (1994). Nosotros somos parte de la tierra. Mensaje del gran jefe Seattle al Presidente de los Estados Unidos en el año de 1855. Palma de Mallorca. Hesperus. 36. 
Instructions for authors, subscriptions and further details:

http://brac.hipatiapress.com

\section{Resistencia y Dolor. Tracey Emin: \\ La Belleza de lo Pecaminoso y la Fragilidad de lo Vulnerable}

Fernando Sáez Pradas ${ }^{1}$

1) Departamento de Dibujo, Universidad de Sevilla. España

Date of publication: February $3^{\text {rd }}, 2015$

Edition period: February 2015 - June 2015

To cite this article: Sáez Pradas, F. (2014). Resistencia y Dolor. Tracey Emin: La Belleza de lo Pecaminoso y la Fragilidad de lo Vulnerable. Barcelona, Research, Art, Creation, 3(1), 13-32. doi: 10.4471/brac.2015.02

To link this article: http://dx.doi.org/10.4471/brac.2015.02

\section{PLEASE SCROLL DOWN FOR ARTICLE}

The terms and conditions of use, except where otherwise noted, are related to the Open Journal System and to Creative Commons Attribution License (CCBY). The indication must be expressly stated when necessary. 


\section{Struggle and Pain. Tracey Emin: The Beauty of Sin and the Fragility of the Vulnerable}

Fernando Sáez Pradas

University of Sevilla

(Received: 16 July 2014; Accepted: 30 November 2014; Published: 3 February 2015)

\section{Abstract}

This article, written in light of the latest news on Tracey Emin, the British artist who faced a barrage of criticism of every kind when her work was shortlisted for the Turner Prize, focuses on the artist's most significant creations, considering their meaning then and now. At present, Emin and her work My Bed (1998) once again find themselves in the cultural media spotlight after the piece reached $£ 2.2$ million at Christie's Auction House following the sale by the Saatchi Gallery. The revelation has reopened the debate which started when the work was unveiled and presents the opportunity to examine how the wound inflicted on traditional British decency has healed. Sufficient time has passed to make a reliable assessment of the reach and impact of the work and consider what has become of the controversy it originally sparked. Alongside a critique of $\mathrm{My} \mathrm{Bed}$, the article will look at the factors which have proved most decisive in shaping the artist's work including influential works of art and aspects of Emin's life.

Keywords: Privacy, transgression, taboo, sex, drawing 


\section{ResistenciayDolor.TraceyEmin: La Belleza de lo Pecaminoso y la Fragilidad de lo Vulnerable}

Fernando Sáez Pradas

Universidad de Sevilla

(Recibido: 16 Julio 2014; Aceptado: 30 Noviembre 2014; Publicado: 3 Febrero 2015)

\section{Resumen}

Tras las últimas noticias acaecidas sobre Tracey Emin, la artista británica que desató una nube de críticas de todo tipo sobre su trabajo cuando fue nominada al premio Turner, desarrollamos en este artículo un análisis focalizado en sus obras más significativas, centrándonos en lo que significaron y lo que suponen hoy en día. Actualmente la artista y su obra My bed (Mi cama) (1998) vuelven a ocupar todas las portadas de la prensa especializada dada la cifra de 3,2 millones de euros alcanzada en subasta en la casa Christie's a través de la galería Saatchi. Con esto se abre de nuevo el debate que la pieza originó en su momento y veremos cómo ha cicatrizado la herida que supuso al decoro británico. Ya hay cierta perspectiva histórica para analizar de manera fiable cual ha sido el alcance y la trascendencia de la obra y en qué se ha traducido tanta polémica. En paralelo a la obra $M y$ bed, profundizamos en aspectos que han resultado ser decisivos para la conjunción de todos los elementos que han dado forma a su trabajo: obras significativas y aspectos de su vida convertidos en producto artístico.

Palabras clave: Privacidad, transgresión, tabú, sexo, dibujo 


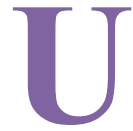

no de los grandes fenómenos de la década de los 90 en la escena internacional ha sido el conocido bajo las siglas YBA's, Young British Artist, o su traducción al español "Jóvenes Artistas Británicos". Una amalgama de adolescentes heterodoxos que se proyectaban al mundo utilizando métodos poco convencionales hasta entonces, aprovechándose de mecanismos más propios del marketing que de los cauces artísticos tradicionales. Damien Hirst, Sarah Lucas, Rachel Whiteread y Chris Offili fueron algunos de ellos, pero en esta investigación nos centraremos en la artista que posiblemente generara más confusión, discusión y controversias. Nos referimos a la británica Tracey Emin, con cuyo trabajo revolucionó el panorama internacional convirtiendo a Londres en el principal escaparate del arte contemporáneo. Fueron dos las obras de la artista que ocuparon la mayor atención mediática, la primera Everyone I have ever slept with 1963-1995 (Todas las personas con las que he dormido), una tienda de campaña con nombres bordados en su interior, y la segunda, My bed, una cama de matrimonio deshecha con objetos de diversa índole a su alrededor. Transgresores aires de cambio que respondían a nuevos contextos sociopolíticos de la era post Thatcher.

En Inglaterra se produjeron transformaciones importantes en los mecanismos para promocionar el arte que marcarían el futuro inmediato del joven arte británico. Fueron tres los ejes principales que promovieron dicho cambio: por un lado los Degree Shows, unas exposiciones frescas realizadas por jóvenes recién graduados que llamaron la atención de los medios de comunicación especializados y galerías; las inversiones realizadas por Charles Saatchi, magnate iraquí afincado en Londres, y la publicidad feroz que hacía de sus adquisiciones; y por último y muy trascendente, la relevancia que adquiere el Turner Prize, un premio dirigido a artistas británicos menores de cincuenta años (Gili, 2001).

Una nueva generación de artistas surgía así tras la era Thatcher y el 20 de octubre de 1999 la candidatura de Tracey Emin (Margate, 1963) al premio Turner se hacía mundialmente conocida. Toda clase de medios de comunicación británicos e internacionales se hacían eco de la noticia. La obra se titulaba My bed y, aparentemente, consistía en una cama de matrimonio, deshecha, sucia y con una variedad de objetos esparcidos por el suelo que nos indicaban los momentos de excesos que había vivido la artista en el lugar. 
Podíamos ver botellas vacías, pañuelos usados, periódicos, unas zapatillas de casa, etc. Un sinfín de suciedad y desorden que se convertía en candidato a ganar el premio de mayor dotación económica a las artes que se concede en Reino Unido. ¿Podría responder tanto desencanto, desarraigo e incluso falta de respeto a la institución y la maquinaria artística, a la profunda crisis económica y social de las políticas conservadoras de Margaret Thatcher?

Resulta significativa la importancia y el debate que ha suscitado su trabajo desde hace años, hoy en boga dada las elevadas cifras económicas que ha alcanzado la pieza My bed en subasta a través de la galería Saatchi. El galerista pretende así recaudar fondos que le permitan continuar con la política de acceso gratuito a sus instalaciones. A pesar de las controversias que genera la artista británica cada vez que aparece en los medios de comunicación, la herida que Tracey Emin le produjo al arte británico en la década de los 90, ha cicatrizado de tal modo, que lo que en su momento fue un revulsivo considerado vulgar, hoy forma parte de la estructura clásica británica; y actualmente ya es académica en la Real Academia de las Artes (Royal Academy of Arts).

\section{Biopic (Biografía Novelada)}

Estudió arte en el Royal College of Art de Londres y posteriormente filosofía. Durante estos primeros años, junto con su compañera Sarah Lucas, abrió una especie de galería-tienda llamada The shop, donde vendían dibujos, camisetas y objetos personales entre otras cosas. Poco después, en 1994, la galería White Cube, una de las más importantes del país, realizó una exposición para Tracey Emin, llamada My Major Retrospective, una especie de efeméride de su propia existencia en la que exponía toda clase de obras, incluyendo juguetes, diarios, dibujos, fotografías... todo relacionado con aspectos muy privados de su vida. Comenzábamos, así, a darnos cuenta de los episodios más oscuros que había atravesado la artista, una truculenta vida privada que iba haciéndose, poco a poco, cada vez más conocida: marginación en la escuela; violada a los trece años; padre y madre prácticamente ausentes en su educación; sufrió de alcoholismo; tuvo problemas de alimentación; perdió dos embarazos, etc. (Elliott \& Schnabel, 2008).

Estos aspectos biográficos serán el fundamento y la base de todo su trabajo. Situar al espectador continuamente en lugares límite de la razón, la moral, la ética y lo legal y transgredir las líneas que marcan lo decoroso serán los ejes 
que articulen la relación de la obra de Emin con el espectador. Su valentía radica en enfrentarse frontalmente con el dolor, al que utiliza como elemento catártico para trascender a través de su obra. Una realidad tan cruda como delicada introduce al que la ve, en un bucle de contradicciones acabando por no saber cuál de las dos descripciones pesa más. Aunque "la imaginación de lo ilícito tiene un alcance limitado" (Nabokov, 2010, pág. 31), veremos cómo Emin es capaz de atravesar fronteras que creíamos infranqueables.

Estamos ante una obra dura, árida, frágil. Una amalgama donde vida y obra se entremezclan convirtiéndose en una misma cosa, y en la que se nos hace difícil encontrar las líneas que las separan, como se nos hacía difícil encontrarlas en Dalí y Warhol, pioneros en estas cuestiones. Manifestaciones multidisciplinares serán las que den forma al cuerpo discursivo: instalación, pintura, vídeo, escultura, fotografía, etc. Aunque, si hay algo que sea una marca identitaria de su trabajo, ésto será el dibujo. Una disciplina que predominará y será una constante desde sus inicios, hasta la actualidad.

\section{La Primera Gran Sorpresa: \\ “Everyone I have ever slept with 1963-1995”, una Tienda de Campaña}

“¿Qué sucede cuando una cosa ya no cumple su función? ¿Sigue siendo la misma cosa o se ha convertido en otra? Cuando arrancas la tela del paraguas, ¿el paraguas sigue siendo un paraguas? Abres los radios, te los pones sobre la cabeza, caminas bajo la lluvia, y te empapas. ¿Es posible continuar llamando a ese objeto un paraguas? En general, la gente lo hace. Como máximo, dirán que el paraguas está roto. Para mí eso es un serio error, la fuente de todos nuestros problemas. Puesto que ya no cumple su función, el paraguas ha dejado de ser un paraguas. Puede que se parezca a un paraguas, puede que haya sido un paraguas, pero ahora se ha convertido en otra cosa. La palabra, sin embargo sigue siendo la misma" (Auster, 2009, pág. 88). 


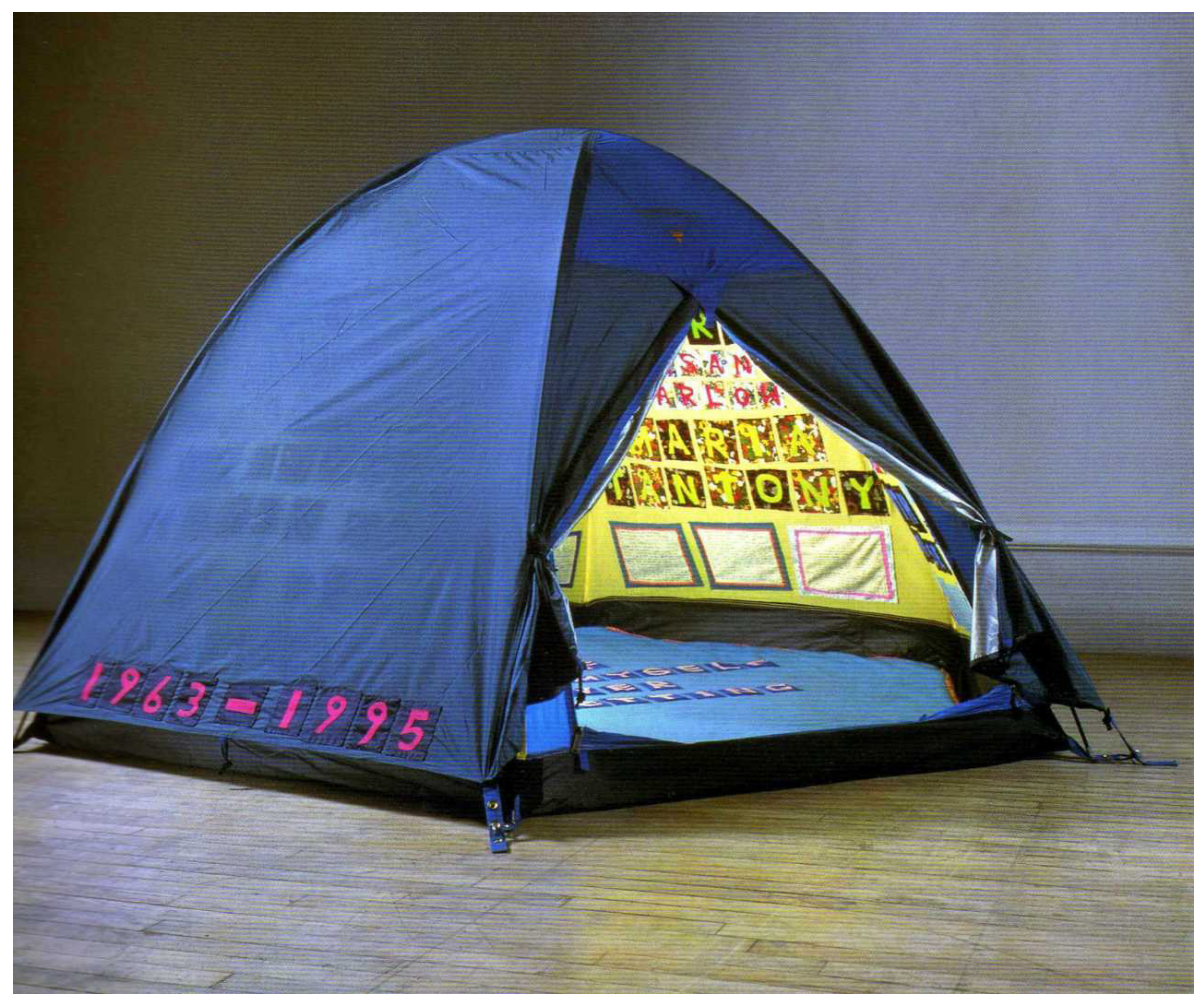

Figura 1. Tracey Emin, "Everyone I have ever slept with 1963-1995” (“Todas las personas con las que he dormido"), 1995. (C) White Cube, Gallery.

Dos cosas importantes: el objeto y la palabra. Ahora bien, ¿podremos seguir llamando a la tienda de campaña, tienda, o a la cama, cama? ¿Se han convertido en otra cosa? Estamos ante una reconstrucción duchampiana, una descontextualización tan brusca como la que hiciera el artista francés, en 1917, con su obra Fontaine (La fuente), estableciendo ahora para la tienda un nuevo código, un valor diferente.

Atendiendo, en primer lugar, a la tienda de campaña (Fig.1.) y observando su título, cotejamos que una traducción literal de éste sería Todas las personas con las que he dormido entre 1963-1995. A simple vista vemos una tienda, de las llamadas tipo iglú, azul en su exterior donde casi a ras de suelo vemos dos cifras numéricas 1963-1995, en su interior aparecen cosidos los nombres de 
todas las personas que han compartido cama con la artista. Una horquilla que abarca desde sus amantes hasta a su propio hermano Paul. Un objeto industrial, una tienda de campaña que podríamos adquirir en cualquier establecimiento especializado o en unos grandes almacenes. Nada la hace especial. Entonces, ¿sigue siendo este objeto una tienda? Si no es así, ¿qué es ahora y por qué?

Rápidamente comenzamos a percibir parte de las intenciones que tiene la artista, y empezamos a elucubrar qué habrá en su interior, qué hace que esta tienda sea diferente a las demás y qué la convierte en una pieza de museo. Aunque esta última cuestión ya no es posible, dado que la pieza se perdió en el incendio del almacén en el que se encontraba, generando con ello gran estupor por la pérdida de numerosas obras (los hermanos Chapman y Damien Hirst también fueron perjudicados), pero aumentando la popularidad de la artista (Fig. 2.).

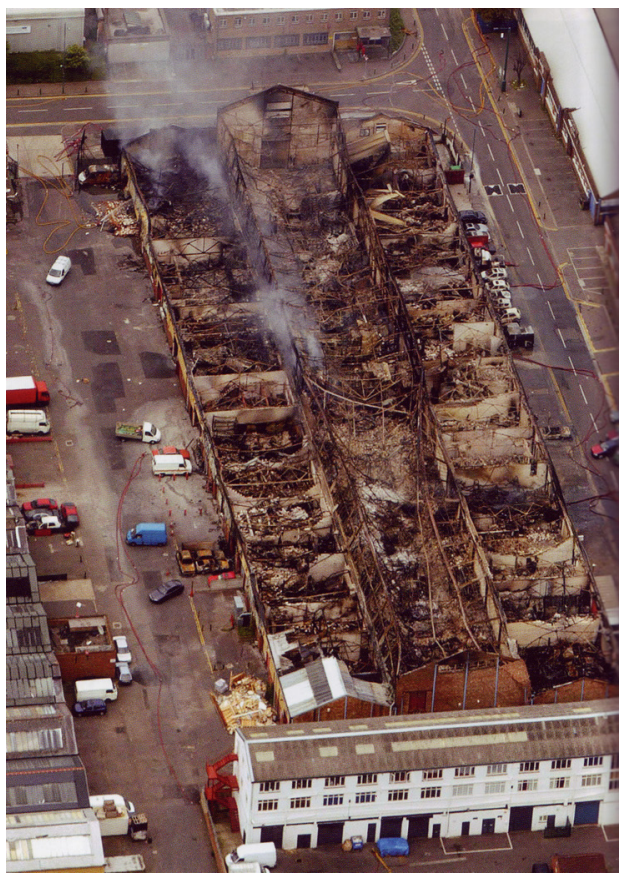

Figura 2. Incendio en los almacenes de Momart, en Leyton, 2000. (C) Rex Features. 
Una primera aproximación a la pieza nos inicia en generarnos la visión que Tracey Emin tiene con respecto al hombre y el sexo, a veces para ella, una misma cosa, dos elementos fusionados en una misma idea. La artista británica ha otorgado a la tienda un nuevo valor, que la convierte en una especie de "harén invertido" (Martín, 2008), invirtiendo el papel histórico en la relación hombre-mujer y su rol activo-pasiva, dominador-dominada. Ella es la dueña del espacio. Antropológicamente tenemos incorporadas las funciones que históricamente se le han atribuido al sexo masculino y al sexo femenino, mientras que la mujer se quedaba en la cueva, el hombre era el que cazaba, el recolector. Actitudes activo-pasivas en las que la mujer cuidaba y criaba y el hombre protegía y alimentaba con sus conquistas animales.

En El baño Turco de 1862, a través de la visión masculina, Ingres hace una referencia literal al concepto de harén clásico. También Picasso lo hizo en obras como El harén, y planteó sus modos de entender el sexo en Las señoritas de Aviñon o en grabados de la Suite Vollard. La historia ha hecho que estemos más familiarizados con la visión masculina, circunscrita a unas prácticas y unos roles sexuales incuestionables, en detrimento de la mirada femenina. Aún más conflictiva se presenta la cuestión, cuando a la visión femenina se le suman los roles que tradicionalmente se han entendido como masculinos, produciéndose así una colisión emocional que nos llena de dudas sin que podamos dar una solución, al menos de manera automática, ya que ninguno de los resortes que tenemos para defendernos de estos ataques funcionan aquí, pues ni el material, ni el procedimiento, y ni siquiera su concepto pueden salvar, en un primer estadio, a esta obra de la quimera académica.

La tienda de Emin es manifiestamente conceptual. Está rescatando con esta obra los ready-made de Marcel Duchamp. Obras como El Gran Vidrio, o La fuente guardan lecturas relacionadas con el sexo, con las bajas pasiones; pero, será en Etant Donnés: $1^{\circ}$ La chûte d'Eau; $2^{\circ}$ Le gaz d'Éclairage (Dados: $1^{\circ} \mathrm{La}$ Cascada, $2^{\circ} \mathrm{El}$ Gas de alumbrado) de 1946-1966, donde encontramos una relación directa con la obra de Tracey Emin. El deseo de observar lo que ocurre dentro, la curiosidad y el morbo irrefrenable acaba convirtiendo al espectador en un voyeur, obligándolo sin que pueda negarse a violar una intimidad incómoda.

Una vez dentro, vemos como con delicadeza y orden, Tracey Emin ha bordado sobre trozos de tela que luego ha cosido a la tienda, los nombres de las personas con las que ha compartido cama. Recupera así una de las actividades entendidas como históricamente femenina: la costura; sólo habría que recordar el mito de Aracne o Penélope. La tienda se convierte en refugio 
como la caverna para el mono de Kubrick, un hogar, una cueva, un vientre, un útero. Para adentrarse, el espectador ha tenido que cruzar la abertura vertical de la entrada, acabando de este modo por convertirse en un falo, en un acto de contraposición de elementos sexuales. La obra de Tracey Emin ha adquirido todas las connotaciones que tuvo el monolito - continuando con Kubrick- y el espectador se ha transmutado en mono y siente y ordena en su interior el desafío, el miedo y la curiosidad, desarrollando por último la valentía en el mejor de los casos, si acaba por penetrar en la intimidad de la artista. Ya hemos visto esta acción en otros artistas, Pedro Almodóvar incluye en su película Hable con ella, 2002, un cortometraje mudo llamado El amante menguante, donde un diminuto hombre camina sobre una mujer como si se tratara de un escenario natural -un campo, o un parque- hasta que encuentra su sexo y entra en el cuerpo de la mujer a través de él, también Niki de Saint Phalle cuando, en 1966, presenta su obra She a cathedral donde hacía que el público recorriera el interior de una gigantesca escultura femenina entrando a través de su órgano sexual. Una especie de parto al revés, una vuelta al hogar.

Si las puertas de la percepción se depurasen / todo aparecería a los hombre como realmente es: infinito. / Pues el hombre se ha encerrado en sí mismo hasta ver / todas las cosas a través de las estrechas rendijas de su caverna. (Blake, 1793).

Una vez atravesada la puerta, estamos en otra esfera, un lugar sagrado, un santuario y aquí sin duda la palabra es importante, con ella Tracey Emin no insinúa sino que señala directamente. (Fig. 3.) Nada de mensajes subliminales. Aquí nos muestra el nombre, dejando a voluntad del espectador, decidir cuáles habrán sido los porqués. ¿Qué valor tiene la escritura?, ella lo dejó claro, "realmente lo mío es la escritura (...) son mis palabras lo que hacen de mi arte algo único" (Martín, 2008, pág. 28). Porque ¿qué es el ser humano sino fundamentalmente lenguaje?, ya decía Heidegger: "El lenguaje es la casa del ser y la morada de la esencia del hombre", el lenguaje cosifica, nomina, es la creación por excelencia en la que se vierte el carácter simbólico del ser humano. Con estos retablos de nombres se inicia el misterio y la elucubración. Todas las dudas nos asaltan y comienzan los juicios inquisitorios, en el peor de los casos, sobre el bien y el mal, lo bueno y lo malo, apelando a una moralidad ancestral donde no se perdona el incesto (Bataille G., 2007, págs. 204-226). 


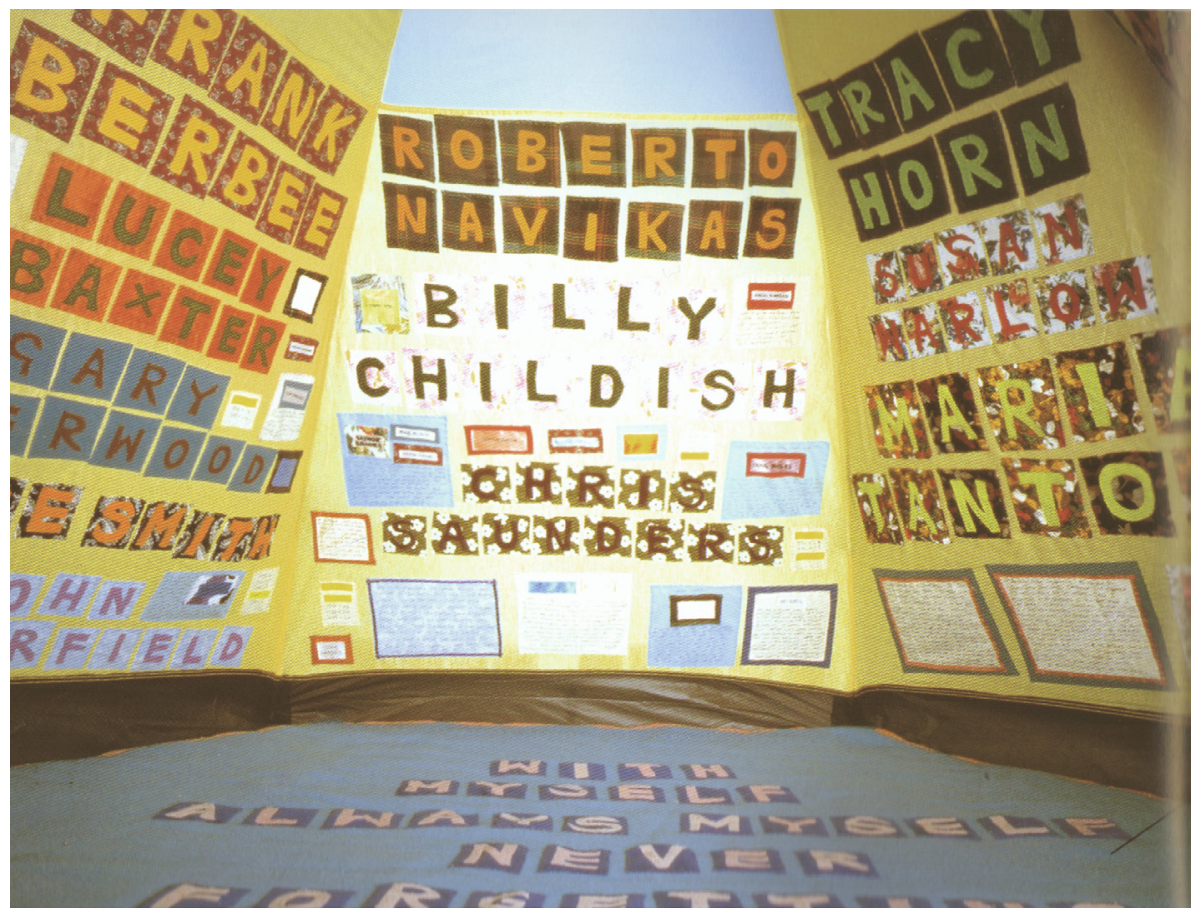

Figura 3. "Tracey Emin, Everyone I have ever slept with 1963-1995” ("Todas las personas con las que he dormido"), 1995. (C) White Cube, Gallery.

En estados emocionales intensos, algunos individuos sienten la necesidad de la exteriorización, refiriéndonos a la escritura en este caso, una actividad que media entre el ser y la cultura y que supone una eternidad en la expresión, pues en su función va intrínseca la permanencia (Choza, 2013). Esto supone un reconocimiento a algo, del mismo modo que lo hacían los menhires o los obeliscos, o en los monumentos donde se conmemora a algún héroe, lleno de símbolos y textos. La tienda de Emin sería otro objeto conmemorativo, una especie de monumento para pobres, relativo a un mundo lumpen, donde se reconocen nombres de héroes - $\mathrm{O}$ villanos- que pertenecen a su submundo. Trofeos y conquistas que quedan anotados a través de lo escrito como si de un libro de firmas se tratase. Ya en el Imperio Romano la escritura espontánea sobre paredes era una cuestión extendida y así han llegado hasta nuestros días, recogidas en las catacumbas romanas o en las ruinas de Pompeya, entre otros lugares. 


\section{BRAC - Barcelona Research Art Creation, 3(1)}

\section{Exposición Pública de un Encierro Voluntario}

La diversificación y especialización de ritos y costumbres de la vida social, y el aumento de su número, pudo dar lugar a una diferenciación incipiente de los ámbitos de lo público, lo privado y lo íntimo, al aumento del contenido de los tres ámbitos y al juego de trasvase de contenidos entre ellos. (Choza, 2013, pág. 147).

En un primer instante Tracey Emin intenta disimular esa ansia de exposición pública refugiando sus pensamientos y experiencias vitales en un lugar cerrado pero, ¿qué ocurre después de la tienda de campaña? Será en Exorcism of the Last Painting I Ever Made (Exorcismo de la última pintura que hice), acción realizada en febrero de 1996, donde la idea de sobreexposición aparece de un modo más destacado.

En esta obra, la artista se encerró durante tres semanas en el interior de la galería Andreas Brändström de Estocolmo. Construyó su estudio en el interior de la galería, trabajando allí en una especie de encierro voluntario durante el tiempo que duró la exposición. Hay que destacar el sistema que se empleó para que los visitantes interactuaran con la artista: unas mirillas. A través de ellas, se podía observar toda la actividad que Tracey Emin desarrollaba en su interior. Una mezcla entre el fenómeno Big Brother surgido a finales de los 90 y el Etand Donnés. La diferencia entre la obra de Duchamp y la de Emin, está centrada en que lo que veíamos en la de ésta, no era un cuerpo inerte y pasivo, sino todo lo contrario. Una mujer en plena actividad y reconciliándose con su trabajo pictórico, pues unos años atrás había quemado toda su producción pictórica, como lo hicieron otros antes -Francis Bacon, por ejemplo-, tras caer en una profunda depresión.

Son muchas las obras y los artistas en los que podemos encontrar el concepto de voyeur al que hacemos referencia. Degás y Picasso son dos ejemplos destacables y de los tradicionalmente más conocidos, aunque son muchos más. Sexo y voyerismo se entremezclan hasta el extremo en la obra Seedbed (Semillero), una performance que Vito Acconci llevó a cabo en la Sonnabend Gallery de Nueva York, en el año 1972. Allí se escondió bajo una rampa durante tres semanas, para masturbarse durante ocho horas al día mientras murmullaba frases como "You're pushing your cunt down on my mouth" o "You're ramming your cock down into my ass" (Saltz, 1972), expresiones soeces con una intención clara de incomodar. La relación que 
Aconcci establece con el espectador es diferente a la que determina Tracey Emin en su acción, mientras el artista estadounidense se esconde para importunar al público, Emin se refugia y no le importa que la observen en su encierro. Aquí la tienda de campaña se ha convertido en un lugar mayor, en cuyo interior podemos encontrar físicamente a la artista, aunque ambos, tanto Acconci como Emin, desarrollan desde su cobijo, su trabajo, interactuando de un modo directo con el espectador.

Allí se dedicó a pintar, utilizando este encierro como un acto de liberación -valga la paradoja-, procedimiento, el de la pintura, que no usaba desde que abortó por segunda vez. No son extraños estos encierros en el contexto del arte contemporáneo, ya Beuys lo hizo en la galería Block de Nueva York, durante tres días y, camuflado entre sábanas y fieltro, con un coyote. Utilizando al "animal sagrado, dios de los indios, elegido como símbolo de américa" (Bernárdez, 2003, pág. 58), para reflexionar sobre la relación entre el arte europeo y el americano.

\section{De cómo una Cama Puede Convertirse en Arte: My Bed}

Utilizando esta performance como puente entre un lugar y otro, la siguiente obra a la que haremos referencia será My bed (Mi cama), de 1998, una obra muy mediática, finalista del Tuner Prize, que supuso un punto de inflexión significativo en la trayectoria de Tracey Emin, aunque por su repercusión y contenido haremos extensible esta importancia a todo el arte británico de los 90, al que situó en un lugar sin retorno. Una pieza que tiene una conexión importante con las dos obras anteriores, una evolución de la tienda de campaña y la performance.

Desde el punto de vista formal, Tracey Emin nos presenta una cama de matrimonio deshecha, con sábanas blancas, sucia, a sus pies una alfombra azul sobre la que quedan esparcidos todo tipo de objetos: pañuelos usados, cigarrillos, condones, un tubo de vaselina, botellas vacías..., entre otras cosas. "A primera vista, los objetos sexuales son ocasión para una continua alternancia entre repulsión y atracción” (Bataille G., 2007, pág. 75). Un justo testigo de la noche al filo del abismo de la que acaba de sobreponerse (Fig. 4.).

Cuando me desperté estaba tan deshidratada que pensé que si no bebía agua me moriría. De alguna manera, no sé cómo, me caí y me arrastré 
a cuatro patas hasta la cocina, cogí una bebida, lentamente di unos pocos sorbos, y volví a la habitación, y allí estaba yo, y todo era agg..., era asqueroso. Y miré hacia la cama y pensé: "Oh, Dios mío, podía haber muerto aquí", y así era como me habrían encontrado. Y entonces, pasé repentinamente de estar horrorizada ante lo que tenía delante, a sentirme distanciada de todo aquello que de repente percibí como algo bello. Me imaginé la escena fuera de aquel contexto, congelada, fuera de mi cabeza en otro lugar (Freeman, 2006, págs. 251-252).

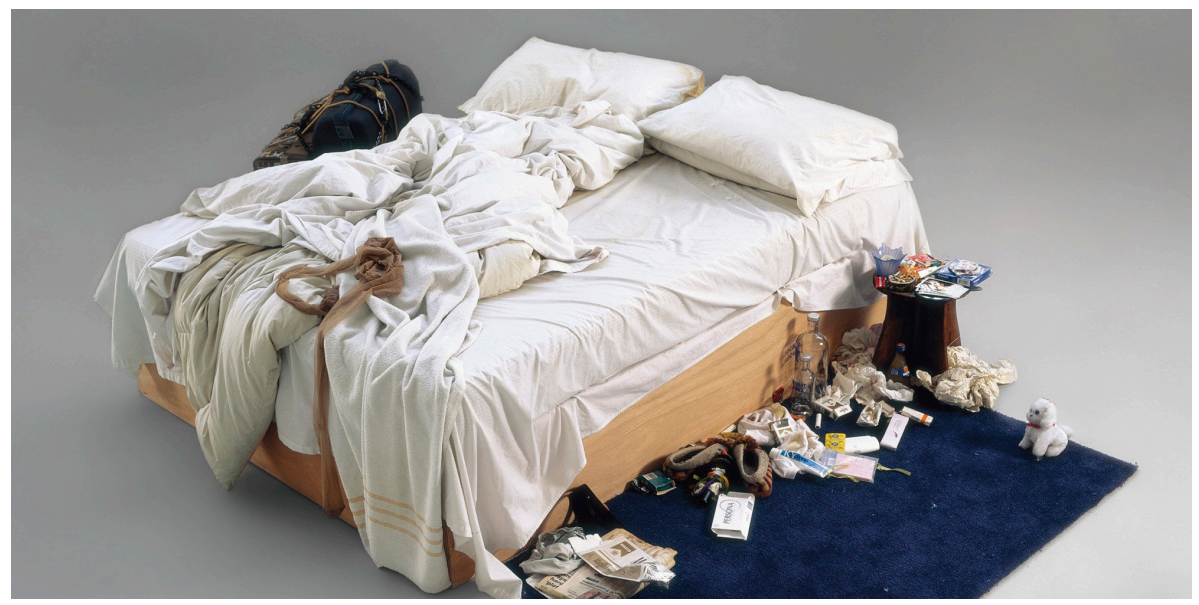

Figura 4. Tracey Emin, "My bed” (“Mi cama”), 1998. (C) Saatchi Gallery.

La separación mental entre la obra y la artista hizo que se marcaran nuevas líneas conceptuales y que nos vengan a la memoria los banquetes que el nuevo realista Spoerri hacía en la Galería J de París, a la que convirtió en un restaurante donde quedaba para cenar con sus amigos. Una vez finalizada la comida, pegaban todo lo que habían usado sobre la mesa, en las que podíamos ver platos, vasos, cubiertos... y la colocaban en posición vertical como si de un cuadro tradicional se tratara. Con ello tornó en arte, a un conjunto de objetos que habían sido testigos de la ceremonia de la comida; objetos de un rito transmutados en arte. De este modo, se transforma en creación, no una actividad, sino su final, con la diferencia de que, en este caso, Daniel Spoerri si tenía una conciencia y unos objetivos generales marcados acerca de cómo 
acabaría su acción; pero, que en Emin no fue así. Mientras Spoerri hizo un teatrillo como excusa para concluir una pieza artística, Tracey Emin no tenía un guion, y hasta que no se distanció de un modo consciente, no fue capaz de ver la dureza de la realidad a la que se había sobrepuesto. Un impacto emocional tan grande como subversivo, en el que acabó por encontrar la belleza de lo pecaminoso en un lugar inhóspito, tan hosco y duro como el espacio que encontramos, 200 años antes, en Saturno devorando a un hijo, o en La balsa de la Medusa, en cuya atmósfera sobrevuelan las debilidades y miserias del ser humano (Bataille G., 2007, págs. 146-152).

Eliminando la ironía y el humor de Piero Manzonni cuando realizó su Mierda de artista, en 1960, Tracey Emin transmuta este detritus igual que el artista italiano. Ha modificado el concepto del contenido, y ha logrado convertir en pieza de museo, en obra artística, un escenario lleno de basura. Un pequeño estercolero que hace al hombre enfrentarse a su lado más lumpen, sórdido y desolador. A una parte oscura del subconsciente que, en el mejor de los casos, podemos tener medianamente adormecida. No representa, presenta. Y este gesto, en el que hay cierta violencia contenida, hace de esta pieza un lugar importante para detenerse o huir. “¡Ah, dijo el pájaro. El género humano no puede soportar demasiada realidad” (Eliot, 2012, pág. 85).

La obra fue expuesta entre los meses de octubre de 1999 y enero del 2000 en la Tate Britain -que no en la Tate Modern-y las dos primevas veces que se exhibió, la pieza llevaba una soga colgando sobre la cama, aunque más tarde, eliminó esta idea.

Existe una brutalidad en la cama de Tracey Emin, extensible a la gran mayoría de sus trabajos, que desborda a quien la ve, "su fuerza está en ser capaz de decir lo que no puede decirse y mantenerse viva después" (Martín, 2008), con una verdad que se clava como concertina. No hay eufemismos, no hay metáforas, no hay ocultación. Se cumplen en su trabajo, de este modo, dos particularidades notables: pasa de lo privado a lo público y eleva el prejuicio a juicio.

Este derramamiento de todo lo que pertenece a la esfera privada y que ella acaba por convertirlo en público, ha hecho de su obra un lugar insoportable debido al exceso en la dosis de realidad. Encontrarse a sí mismo como tarea significa situarse al borde del abismo, (Kierkegaard, 2007), y esto da miedo, genera un sentimiento de estrechamiento, de angostamiento, de ansiedad... Una angustia de la que ha conseguido desprenderse verbalizándola, compartiéndola sin pudor, como si de un acto psicoanalítico se tratara, ha pasado de lo inconsciente a lo consciente. 
La preocupación por los ciclos biológicos fundamentales del ser humano-ya sean biográficos o no- y de los que destacaremos la muerte y la reproducción, preocuparon también a otro compañero de su generación: Damien Hirst. Tomaremos como ejemplo de ello la obra A Thousand Years, de 1990, una estructura rectangular de $213 \times 427 \times 213 \mathrm{~cm}$. en cuyo interior hay una cabeza de vaca pudriéndose, donde nacen larvas que se transforman en moscas, y que posteriormente completan su ciclo vital falleciendo cuando impactan con un circuito eléctrico situado dentro. Nacer, crecer, reproducirse y morir, un esquema conceptual de las preocupaciones de Hirst que tuvieron su eco en el trabajo de Tracey Emin. Ambos fueron los artistas de esta generación que más proyección internacional han tenido, y Hirst ha encabezado durante muchos años la lista de los artistas más importantes del mundo.

En My bed, cierto componente religioso sobrevuela; la idea de tocar fondo; el morir conceptualmente para renacer trayendo consigo la verdad revelada por el subconsciente; la percepción del escenario que tiene Tracey Emin como si fuera un sujeto externo, ya trascendido; la idea de culpa; la moralidad, el bien y el mal; la transmutación de la materia como si de una transustanciación se tratase... "En la historia del erotismo, la religión cristiana desempeñó una función clara: su condena" (Bataille G., 1997, pág. 97).

\section{El Dibujo y su Componente Narrativo}

En paralelo a las obras a las que hemos hecho referencia, Tracey Emin ha desarrollado a lo largo de su carrera una complejísima y numerosa serie de dibujos, una colección gráfica imprescindible para cualquier estudioso de su trabajo. Gran parte de ellos quedan recogidas en la publicación One Thousand Drawings (Mil dibujos), un compendio de mil dibujos realizados sobre papel con diferentes técnicas, desde 1988 hasta 2007.

Estos dibujos han resultado ser una obra muy significativa y completa que explican perfectamente todas las inquietudes que ha desarrollado la artista a lo largo de su vida. En ellos vemos una amplia iconografía relacionada con su entorno y su vida cotidiana: la familia, animales, paisajes..., un gran número de preocupaciones aparecen en este legado gráfico, entre las que destacaremos la que será una constante: el sexo.

Antropológicamente, desde que el ser humano ha tenido relaciones sexuales, éstas han sufrido un gran cambio conceptual, las acciones han pasado de lo animal a lo humano provocado por una transformación intelectual 
en el proceso: "La sexualidad en el hombre evolucionó desde una práctica sin vergüenza hasta una experiencia pudorosa, que acabó derivando en lo que conocemos como erotismo. Una transformación de animal a humano" (Bataille G., 2007, pág. 35) ¿Puede trascender la artista a través del sexo y en partes iguales su lado animal y el más intelectual? cuando el sentido común y la razón desparecen, estamos abocados a adentrarnos en un mundo terrible, "el sueño de la razón produce monstruos" decía Goya. No sabemos con certeza si lo que duerme en Emin es la razón o el corazón, en cualquier caso, vemos en sus dibujos un mundo terrible. Son trabajos que cabalgan entre el universo oscuro de las pesadillas de Goya y una ínfima esperanza de encontrar la felicidad, para ella, relacionada con el amor y la libertad personal.

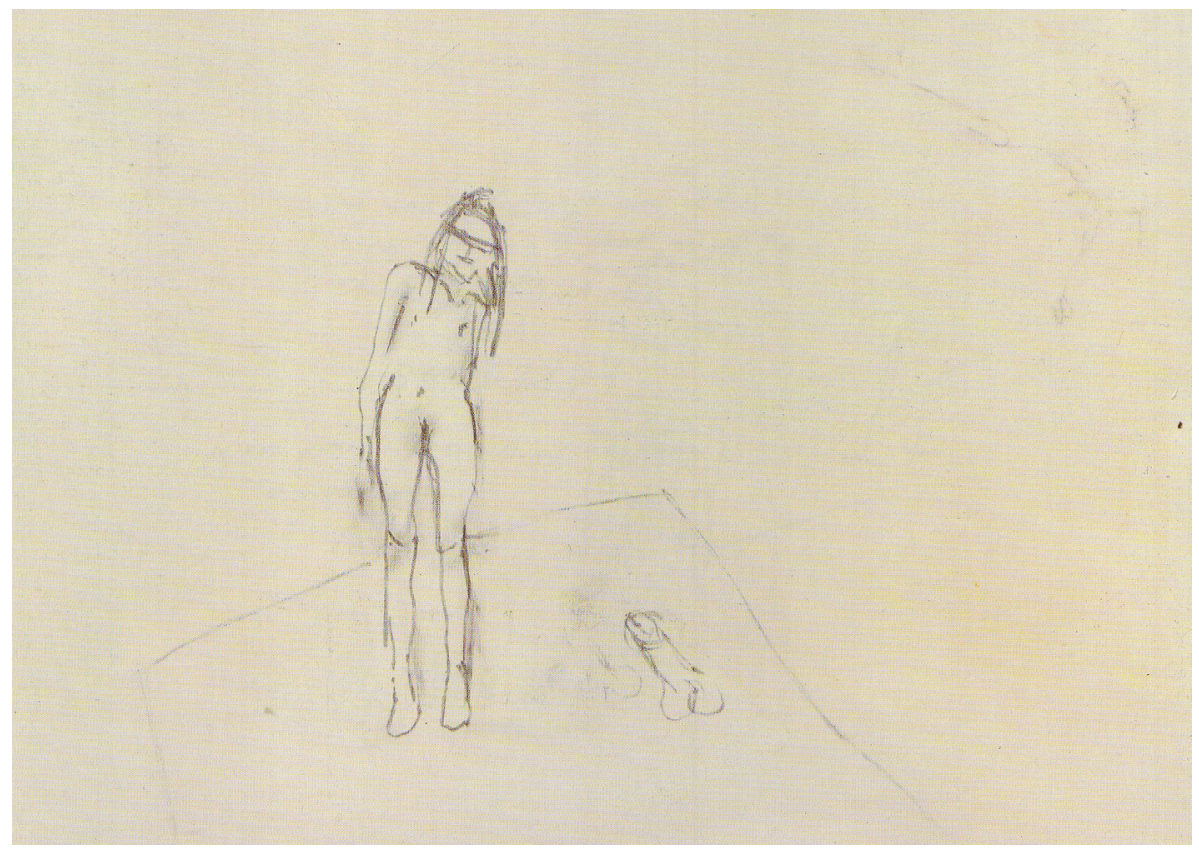

Figura 5. Tracey Emin, "Beautiful Child" ("Niño bonito"), 1999. (C) “One Thousand Drawing". 
"El dibujo es un lenguaje alquímico. Algunos de los dibujos favoritos que he realizado, los he hecho con los ojos cerrados" (Emin, Ghosts of my past / Los fantasmas de mi pasado, 2009). El automatismo en el proceso se apodera de ella, que suele trabajar desde el recuerdo, desde las imágenes que ha visionado en su mente en algún momento, y que de manera semiconsciente dispone sobre el papel. "Soy la que dirige las imágenes que viven en mi mente. Todas las imágenes primero han estado en mi cabeza y viajado a través de mi corazón, de mi sangre, llegando finalmente a mi mano" (Emin, Ghosts of my past, 2009). Un método instintivo vinculado al mundo surrealista en su procedimiento, aunque quede más ligado al expresionismo en su aspecto formal.

Los artistas que marcaron a Tracey Emin fueron indudablemente los expresionistas y su visión subjetiva de la realidad-naturaleza. Egon Schiele y Edvard Much serán los principales referentes para su trabajo gráfico, en el que destaca la línea, "una línea oscura y nerviosa que se ensombrece por las marcas y manchas causadas en parte por la presión de la pluma y en parte por los dedos o las manos de la artista al pasar por encima del papel. La línea se detiene y sangra, sugiriendo fragilidad y vulnerabilidad, como un corte o una cicatriz" (Elliott \& Schnabel, 2008, pág. 28). Un sentimiento de desarraigo y soledad lo inunda todo, donde, de manera sistemática quedan patentes sus preocupaciones con respecto al sexo. En Beautiful Child (Niño bonito), de 1999, vemos como se representa frente al hombre. La artista realiza un dibujo de una adolescente de pie, desnuda y de frente, sobre un espacio tridimensional que queda determinado por una especie de rectángulo en el suelo a modo de alfombra. La representación del hombre queda limitada a su órgano reproductor, lo ha simplificado y reducido a un elemento fálico. La comunicación entre ellos es nula, no sabemos si ha habido contacto o no, o si lo habrá en un futuro próximo, incomunicación que se traduce en incómoda tensión entre la pulsión de Eros y Tánatos.

La necesidad de verbalizar a través del dibujo sus dramas personales se convertirá en su particular terapia psicoanalítica. La visión dramática y voraz de representar la sexualidad y el erotismo hace que la línea que las separa de la pornografía sea sutil, "los criterios tradicionalmente empleados para establecer la distinción entre lo erótico y lo pornográfico no sólo carecen de base científica sino que, además, son fácilmente rebatibles en cuanto cambiamos de ámbito cultural o temporal. Dichos criterios son la dicotomía realidad/ficción, la falocracia y la elipsis o presencia visual". 


\section{La Transgresión, la Eliminación del Tabú y la Acción de la Memoria como Agente Reconstructivo}

En la tienda nos ofreció de manera tímida su vida privada, sus relaciones personales a través de la palabra, todas ellas, ocultas en el iglú. Después, en la performance que realiza en Estocolmo se oferta ella misma, invita a participar al espectador para que la observe. Y por último, en My bed muestra los residuos de varios días de excesos. Del modo tímido -que no introvertidoque se muestra al principio, sólo indicando las personas con las que había compartido su lecho, aclarando que no necesariamente habían sido encuentros sexuales, pasa a, sin ningún tipo de pudor, enseñar la propia cama, eliminando las palabras y mostrando el lugar del crimen.

Bajo estos tres eslóganes podríamos dirigirnos hacia los resultados finales de esta investigación. "La transgresión no es la negación de lo prohibido, sino que lo supera y lo completa" (Bataille G., 2007, pág. 67). Continuamente cruzando la frontera de lo establecido como decoroso en el subconsciente colectivo, hace que la transgresión sea una de las características más significativas y rápidamente visibles en su trabajo. Es capaz de decir lo que no se puede decir, lo que socialmente está prohibido, eliminando de este modo cualquier forma de tabú. Estos son sus lugares preferidos, los considerados sagrados, inviolables y sobre los que no se puede verbalizar por el resto de la gente. Ahí es donde Tracey Emin deposita toda su fuerza, se descarga de energía en estos espacios psicológicos sujetos a veto como si sólo de este modo pudiera obtener su redención.

Y así entra en juego la imaginación, una facultad parecida a un archivo de cualidades sensibles. A través de una experiencia somos capaces de reconstruir una totalidad. La fantasía nos permite la reconstrucción del concepto y no está sometida al tiempo. Con la imaginación podemos combinar los estímulos como pensemos oportuno y por eso es creadora, podemos coger un caballo y un hombre y fabricar un centauro, inventar mitos, quimeras, crear a Pegaso o titanes. Con los trabajos de Tracey Emin el público queda mudo, un silencio que usa como vehículo para llegar a otro lugar. Un lugar en el que la imaginación reconstruye el suceso, por lo que cada una de las obras será diferente para cada uno de los presentes, ya que sigue sujeta a la reconstrucción subjetiva por parte de éstos, utilizando la obra para verbalizar aspectos a los que nunca fue capaz de enfrentarse.

La decadencia, el declive, la pérdida de un camino vital, de su camino. Cada 
uno de sus trabajos acaba convirtiéndose en un grito de auxilio y cada uno de sus dibujos en uno de sus tantos episodios dolorosos. ¿Será esta confrontación con la realidad, a la que permanece sujeta el espectador, su pequeña venganza?

\section{Referencias}

Auster, P. (2009). La trilogía de Nueva York (22 ed.). Barcelona: Anagrama. Bataille, G. (1997). Las lágrimas de Eros. Madrid: Tusquets.

Bataille, G. (2007). El erotismo. Madrid: Tusquets.

Bernárdez, C. (2003). Joseph Beuys ( $3^{\mathrm{a}}$ ed.). San Sebastian: Nerea.

Blake, W. (1793). Las bodas del cielo y el infierno. Revista Culturamas.

Recuperado de http://www.culturamas.es/blog/2012/05/17/williamblake-el-matrimonio-del-cielo-y-el-infierno/

Choza, J. (2013). Filosofía de la cultura. Sevilla: Thémata.

Eliot, T. S. (2012). Cuatro cuartetos ( $8^{\mathrm{a}}$ ed.). (E. Pujals Gesalí, Trad.) Madrid: Cátedra.

Elliott, P., \& Schnabel, J. (2008). Tracey Emin 20 años. Málaga: CAC Málaga.

Emin, T. (25 de mayo de 2009). Ghosts of my past. The Guardian.

Recuperado el 14 de septiembre de 2013, de http://www.theguardian.

com/artanddesign/2009/may/25/tracey-emin-drawing-art

Freeman, C. (2006). Tracey Emin: Works 1963-2006. Nueva York: Rizzoli.

Gili, J. (2001). Muestras anuales. Plataformas y trampolines. Lápiz $(169 / 170), 122-127$.

Kierkegaard, S. (2007). El concepto de la angustia. (D. G. Rivero, Trad.) Madrid: Alianza Editorial.

Martín, F. J. (Diciembre de 2008). Tracey Emin. Un alma. Arte y parte (78), 25.

Nabokov, V. (2010). El ojo. (J. A. Masoliver Ródenas, Trad.) Barcelona: Anagrama.

Saltz, J. (1972). Seedbed. UbuWeb Film. Recuperado de http://www.ubu. $\mathrm{com} /$ film/acconci_seedbed.html 
Fernando Sáez Pradas: Personal Investigador en formación. Departamento de Dibujo. Universidad de Sevilla.

Contact Address: Facultad de Bellas Artes. C/Laraña n³, CP 41003 , Sevilla.

E-mail address: fsaez@us.es 
Instructions for authors, subscriptions and further details:

http://brac.hipatiapress.com

\section{La Subjetividad y la Fantasía en la Creación Plástica: Sus Procesos Psicológicos y Simbólicos en el Arte Infantil y Primitivo}

Belén León Río ${ }^{1}$

1) Universidad de Sevilla. España

Date of publication: February $3^{\text {rd }}, 2015$

Edition period: February 2015 - June 2015

To cite this article: León Río, B. (2014). La Subjetividad y la Fantasía en la Creación Plástica: Sus Procesos Psicológicos y Simbólicos en el Arte Infantil y Primitivo. Barcelona, Research, Art, Creation, 3(1), 33-58. doi: 10.4471/ brac.2015.03

To link this article: http://dx.doi.org/10.4471/brac.2015.03

\section{PLEASE SCROLL DOWN FOR ARTICLE}

The terms and conditions of use, except where otherwise noted, are related to the Open Journal System and to Creative Commons Attribution License (CCBY). The indication must be expressly stated when necessary. 


\section{The Subjectivity and Fantasy in Artistic Psychological Creation: Its in Child and and Symbolic Primitive Art Processes}

Belén León Río

University of Sevilla

(Received: 6 May 2014; Accepted: 7 Desembre 2014; Published: 3 February 2015)

\section{Abstract}

Symbolism in art is largely connected with the structure of the unconscious, as children do in their artistic manifestations sometimes finding the same images and metaphors that have occurred in the art from older periods as prehistory this would lead us to believe that there is no single idea or concept that has no essential historical background, all based ultimately archetypal primitive forms, which are evident in the art through a consciousness that does not act only through thought but sees internally. In this article you will see how the unconscious would not be just a mere repository of the past, but is also full of germs of future psychic situations and creative ideas, the not few artist sometimes be their best work to the inspirations that appear suddenly unconscious, it would exert a great influence on the mythological, religious, artwork and all other cultural activities that the human being is expressed.

Keywords: Reason, intuition, unconscious, archetype, symbol, fantasy 


\section{LaSubjetividadylaFantasíaenla Creación Plástica: Sus Procesos Psicológicos y Simbólicos en el Arte Infantil y Primitivo}

Belén León Río

Universidad de Sevilla

(Recibido: 6 Mayo 2014; Aceptado: 7 Diciembre 2014; Publicado: 3 Febrero 2015)

\section{Resumen}

El simbolismo en el arte está conectado en gran medida con la estructura de lo inconsciente, al igual que hacen los niños en sus manifestaciones plásticas encontrándose a veces las mismas imágenes y metáforas que se han producido en el arte de otros periodos más antiguos como la prehistoria, esto nos llevaría a pensar que no existe una sola idea o concepción esencial que no posea antecedentes históricos, todas se basan en última instancia en formas primitivas arquetípicas, que se hacen patentes en el arte a través de una consciencia que no actúa sólo a través del pensamiento sino que percibe internamente.

En este artículo veremos como el inconsciente no sería sólo un mero depositario del pasado, sino que también está lleno de gérmenes de futuras situaciones psíquicas e ideas creativas, el artista no pocas veces, debe sus mejores obras a las inspiraciones que aparecen súbitamente del inconsciente, éste ejercería una gran influencia en el material mitológico, religioso, artístico y en todas las demás actividades culturales con las que se expresa el ser humano.

Palabras clave: Razón, intuición, inconsciente, arquetipo, símbolo, fantasía

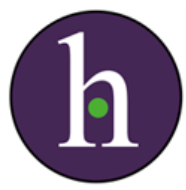




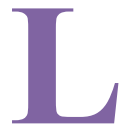

a mente inconsciente del hombre moderno conserva la capacidad de crear símbolos siendo el arte un canalizador de estos, ya que además de las formas que percibimos trasmiten mensajes que influyen en nuestra consciencia. De lo inconsciente surgirían efectos determinantes que aseguran en todo artista la similitud y aun la igualdad de la experiencia y de la creación imaginativa, lo que explicaría la coincidencia de muchas de estas imágenes arquetípicas a lo largo de la historia del arte y su identificación con el espectador que participaría igualmente de ellas. La creación artística es un campo de exploración idóneo de los productos de lo inconsciente, donde descubrimos a menudo estructuras arquetípicas o simbólicas que coinciden con temas míticos. Una de las pruebas fundamentales de esto es el paralelismo que podríamos calificar de universal, entre los temas mitológicos representados una y otra vez en la historia del arte. Esto no implica que la actividad artística pueda conocerse solamente por su fundamento arquetípico pero sí podemos tener en cuenta que dentro de ésta existen modelos arquetípicos que actúan con una dinámica de fondo que descifran el mensaje de ciertas tendencias evolutivas del inconsciente.

Esta forma de pensamiento funciona sin esfuerzo, espontáneamente y es dirigido por motivos inconscientes, se aparta de la realidad liberando tendencias subjetivas. El mito estaría emparentado con los productos del inconsciente y el artista en proceso de introversión encuentra muy a menudo en su obra reminiscencias del pasado individual además de numerosas huellas de estadios espirituales arcaicos. Como vemos el artista que se expresa simbólicamente, establece un enlace con los estratos más antiguos del espíritu humano, desde largo tiempo atrás sepultados por debajo del umbral de la consciencia, este mismo simbolismo se puede ver en las manifestaciones plásticas infantiles, detectándose desde que el niño empieza a dibujar sus primeros garabatos.

Mientras el individuo de hoy en día concentra toda su energía e interés en la ciencia y en la técnica, el hombre antiguo se consagraba a su mitología, encontramos aquí un mundo de fantasía que manaba de una fuente interna y que producía figuras plásticas o esquemáticas que concordaban con su esencia más profunda (revisar frase). C. G. Jung, llegó a la conclusión de que la época que creó los mitos pensaba de la misma manera que hoy lo hace el sueño. Incluso se descubren fácilmente en los niños rudimentos de mitos en formación y fantasías consideradas como reales. Bastaría con relajar el 
interés para eliminar la exacta adaptación psicológica al mundo real, que se expresa por medio del pensamiento dirigido y sustituirla por fantasías. Según este autor, nuestro cuerpo conserva en muchos órganos residuos de antiguas funciones y estados, así también, nuestro espíritu, aun cuando en apariencia ha superado aquellas arcaicas tendencias instintivas, lleva siempre la huella de la evolución recorrida y revive en los sueños, en la imaginación y a través del arte las épocas más distantes. De esta manera la mente humana tendría su propia historia y la psique conservaría muchos rastros de las anteriores etapas de su desarrollo, los contenidos del inconsciente ejercerían una influencia formativa sobre la psique. E. Pérez de Carrera describe como el arte tiene sus orígenes en el símbolo utilizando los sentidos hacia formas de consciencia que despierten emociones paralelas en la percepción de la obra plástica:

La escritura pictográfica tuvo mucho de simbólica. De pintar un caballo se pasó a metamorfosear con atributos equinos aquellos que habían demostrado cualidades especiales como la velocidad o la resistencia. Del caballo con cabeza humana se pasó a grabar un rostro o una característica como la huella de un casco o las ondas de las crines. Esta capacidad simbólica de llegar a sintetizar en un rasgo las características zoológicas, morfológicas o de fenómenos relacionados con la Naturaleza adquiere caracteres de un verdadero lenguaje con varios niveles paralelos de lectura, y quizá su principal cualidad sea que pueden ser percibidos más de un escalón de comprensión al mismo tiempo. La utilización de los sentidos hacia formas de consciencia que despiertan emociones paralelas es una de las fuentes de la poesía y el arte, y nace ligada al gráfico, al rasgo, al símbolo, al movimiento y a la necesidad mágica de vivir realidades ensoñadas.

De esta forma de compartir experiencias, de la que el arte de las cuevas $<$ prehistóricas $>$ es una referencia testimonial, quedan aún ejemplos en la escritura japonesa de sílabas y palabras que tienen su origen en el dibujo. El valor añadido de los idiomas ortográficos, de palabras que intentan contener un significado concreto, es la facilidad de intercambiar un pensamiento. El verso comulgado, la conversación, disminuyen en cierto modo la transmisión mistérico-mágica pero aumenta la comunicación ético-filosófica, proporcionando riqueza interior para enfocar la aventura individual del pensamiento. (2004, pp. 259 y 260) 
Sri Aurobindo ya menciona como las sociedades humanas en sus primeros comienzos o en fases primitivas solían tener una mentalidad marcadamente simbólica que impregnaba sus pensamientos, costumbres e instituciones. Este estadio de su desarrollo social era siempre religioso y activamente imaginativo en su religión, pues para este autor existe un parentesco natural entre simbolismo y el sentimiento generalizado, imaginativo o intuitivo, de modo que ambos van siempre a la par. De esta forma el símbolo expresaría algo que el hombre siente que está presente detrás de sí mismo, de su vida y de sus actividades: "el Divino, los dioses, el vasto y el profundo Inefable, una naturaleza de las cosas oculta, viva y misteriosa". (2002, p. 22)

El arquetipo sería la imagen de un contenido en su mayor parte trascendente a la consciencia. Un ejemplo de ello sería el símbolo mandala, cuya existencia a través de los milenios puede comprobarse en multitud de culturas y que en el arte aparece en todas las épocas, simboliza el fenómeno de la divinidad encarnada en el hombre. Estos arquetipos representan esencialmente un contenido inconsciente, que al ser percibido cambia de acuerdo con cada consciencia individual en que surge, de ahí las grandes diferencias en la representación artística de un mismo arquetipo en varios autores, incluso perteneciendo a una misma época. De lo inconsciente surgen así efectos determinantes que, independientemente de la transmisión, aseguran en el artista la similitud y aún la igualdad de la experiencia, expresándose en imágenes simbólicas surgidas a través de la creación que variarán de un artista a otro, en función de cada consciencia individual y transformándose en un mismo autor a lo largo de su evolución artística. En el arte vemos como estas representaciones no se heredan, sino en las formas que pueden variar infinitamente. La actividad creadora, estaría propulsada y regulada por estas "condiciones inconscientes colectivas" como las llamaría C. G. Jung, (1994, p. 148) produciendo configuraciones plásticas donde se repiten estructuras idénticas como por ejemplo la unificación de los contrarios en un tercero, la cuaternidad, el cuadrilátero, la cruz, la rotación, el círculo, la esfera, etc.

Estos arquetipos vivos formularían un fragmento inconsciente esencial y cuanto más universal sea la difusión de ese fragmento, tanto más universal será la acción del símbolo, pues roza en el artista y en el espectador la cuerda que le es afín; y siendo la más alta expresión posible de lo presentido y aún no sabido, incluyen en sí la atmósfera espiritual de su época, captando justo aquello que puede ser común a un gran grupo humano, produciendo en tales circunstancias una participación inconsciente. El arquetipo tendrá, por lo tanto, un lado que es accesible a la razón, pero también un lado, que es inaccesible 
a ésta, por cuanto está compuesto, no sólo, de datos de naturaleza racional, sino también, de los datos irracionales de la pura percepción interna y externa. La abundancia de presentimientos y significados del símbolo, hablan tanto al pensar, como al sentir, y su peculiar carácter de imagen cuando se configura en una forma sensorial artística, estimulan tanto la sensación como la intuición. El arte adquiere así un contenido que impresiona, influye y fascina, a través de una pre-forma inconsciente que parece pertenecer a la estructura heredada de la psique y puede a causa de ello, manifestarse como fenómeno espontáneo en el proceso artístico plástico, según C. G. Jung a través, del pensamiento fantaseador se establece un enlace con los estratos más antiguos del espíritu humano:

... toda buena idea y todo acto creador han brotado de la imaginación y han tenido su inicio en eso que pueda llamarse fantasía infantil. No sólo el artista, sino todo hombre creativo a de agradecer a la fantasía lo más grande que hay en su vida. El principio dinámico de la fantasía es lo lúdico, lo cual es también algo propio del niño; como tal, aparece asimismo incompatible con el principio del trabajo serio. Pero hasta ahora nunca ha nacido una obra creativa sin ese juego con la fantasía. Es incalculable lo que debemos a la fantasía. Por ello es miope tratar con desdén las fantasías en razón de su carácter aventurero o inadmisible. (1994, pp. 87 y 88 )

Autores y artistas se han interesado por el mundo simbólico artístico de los niños. Hegel decía del arte infantil:

Los intentos que hacen los niños de dibujar o modelar la figura humana dan como resultado meros símbolos, que sólo aluden a la forma viva que pretenden representar pero no son nada fieles a sus motivos y sus significados. En este aspecto, el arte es el principio puramente jeroglífico, no un signo fortuito o arbitrario sino una vaga representación del objeto para la mente. ${ }^{1}$

En Alemania el psiquiatra Hans Prinzhorn publicó en 1922 gran número de trabajos de pacientes mentales en su volumen Bildnerei der Geistes Kranken que provocaría una enorme conmoción entre los artistas y aficionados al arte donde señalaba: 


\section{BRAC - Barcelona Research Art Creation, 3(1)}

Sólo un tonto pensaría que lo que tiene de personal el sonido de un violinista se puede determinar midiendo las ondas sonoras y el registro armónico, o que el contenido expresivo de un Rembrandt de la última época se puede examinar mediante comparaciones con una tabla de colores.

Hacemos un compendio contrastando la esfera de los datos medibles con el reino de los datos expresivos, en el que los contenidos psíquicos aparecen inmediatamente y se captan sin la mediación de un aparato intelectual. Todos los movimientos expresivos sirven para este único fin: incorporar lo espiritual y así construir un puente desde el Yo al Tú [...] Encontramos las raíces de esto en circunstancias bien simples: con los niños, que en sus juegos inventan una animada danza o hacen garabatos, cuyo valor expresivo habla claramente al iniciado; o con los primitivos, que en sus máscaras de baile expresan de algún modo su visión del mundo, imbuida de ideas mágicas y demoniacas $[\ldots]{ }^{2}$

Nos encontraríamos aquí frente a un proceso psíquico que se desarrollaría preferentemente en lo inconsciente, donde la fantasía tendría que ver con el impulso lúdico o de juego, el artista plástico y todo hombre creativo deben mucho al principio dinámico de la fantasía, ya que, no hay que olvidar que lo más valioso del ser humano puede hallarse precisamente en su imaginación. El niño sacaría a la luz mediante ese juego con la fantasía lo que encerraría en su esencia más íntima, plasmándola en la materia plástica. En estos dominios de la fantasía, gran parte de sus contenidos pertenecen al inconsciente y la otra parte se encuentra en lo consciente, por lo que sólo a través de la imaginación, se establecería un enlace con nuestro pasado inconsciente, reviviendo en el arte las épocas más distantes.

\section{El Subjetivismo y la Fantasía en la Actividad Artística}

La fantasía creadora, dispondría no sólo de las fuentes personales del individuo, sino también del espíritu primitivo ya olvidado y sepultado por el tiempo. En el arte pueden aparecer como figuras abstractas que se expresan también en las mitologías de todos los pueblos y épocas. El conjunto de estas imágenes sería este inconsciente colectivo que todo ser humano heredaría en potencia. Estas imágenes surgirían de manera espontánea y coincidirían entre sí en todas las épocas y lugares del mundo. Mediante la fantasía nos apartaríamos de la 
realidad, liberando tendencias subjetivas las fantasías del artista manarían de una fuente interna, produciendo representaciones muy variadas.

El vínculo que tendría el espectador con la fantasía estaría condicionada principalmente por su relación con lo inconsciente en general, esta última relación se hallaría a su vez especialmente condicionada por el espíritu de la época de tal manera que si el grado de racionalismo predominante fuera alto el individuo se inclinaría menos a admitir lo inconsciente y sus productos, y viceversa. En el inconsciente, los elementos más heterogéneos se remplazarían los unos a los otros, de tal manera que todo aquello que en la consciencia estaría separado y es opuesto, confluiría en agrupaciones y configuraciones que, una vez llevadas a la luz de la consciencia, ya no aparecerían como contrarios. El psicólogo francés Théodule Ribot dice que la edad de oro del símbolo fue la época prehistórica:

Desde entonces ha sido arrollado por la presión hostil del pensamiento racional que, reforzado por la experiencia y por la razón misma, ha ido ganando terreno constantemente... La razón de ser del símbolo radica en la voluntad humana de expresar lo que es intrínsecamente inexpresable. ${ }^{3}$

La fantasía en su mayor parte es un producto de lo inconsciente, aunque también contiene partes conscientes. Sería esencialmente involuntaria, enfrentándose como algo extraño al contenido consciente. El material aflorado de la fantasía contendría imágenes del desarrollo psicológico del individuo en sus estados sucesivos, C. G. Jung lo compara con un trazado o una descripción del camino a seguir más tarde entre los opuestos. Según este autor, a pesar de que la consciencia a menudo no encontraría mucho que entender directamente en las imágenes, estas intuiciones contendrían sin embargo una "fuerza de vida" que puede causar un efecto determinante en la voluntad. Esta determinación de la voluntad se ejercería por ambos lados, por lo que pasado algún tiempo, los opuestos se volverían a fortalecer. Pero este renovado conflicto forzaría al individuo a recorrer otra vez el proceso, de tal manera que el individuo podría dar un paso más. Esta función mediadora de los opuestos fue llamada por C. G. Jung "función transcendente". Aquí la fantasía creativa tendría la función de unir los opuestos.

C. G. Jung decía que la infancia, gracias a su ingenuidad, proyecta una imagen más completa del ser humano, de todo el hombre en su individualidad 
auténtica, a consecuencia de ello la visión del niño y del primitivo despertaría en el hombre adulto anhelos que provienen de deseos y necesidades insatisfechos. Según este autor, estas partes correspondientes de la personalidad fueron retocadas en la persona a partir de la imagen de conjunto del hombre en beneficio de la adaptación:

El europeo, determinado en gran parte por su racionalidad, es mucho más ajeno a lo humano y de ello se envanece algo, sin darse cuenta de que ello se hace a costa de su intensidad de vida y que a causa de ello la parte primitiva de la personalidad es condenada a una vida existencia parcial subterránea. (1996, p. 251)

Paul Klee en 1912 comenta en su diario:

Porque éstos son los comienzos primitivos del arte, tal como se suelen encontrar en las colecciones etnográficas o en casa, en el cuarto de los niños. ¡No te rías lector! También los niños tienen capacidad artística, y hay sabiduría en que la tengan. Cuando más desvalidos son, más instructivos son los ejemplos que nos ofrecen; y se los debe mantener libres de corrupción desde que son muy pequeños. Las obras de los enfermos mentales nos ofrecen ejemplos paralelos; ni "conducta infantil" ni "locura" son aquí palabras insultantes, como suele serlo. Todo esto hay que tomarlo muy en serio. Más en serio que a todas las galerías públicas, cuando se trata de reformar el arte actual. ${ }^{4}$

En el niño de dos a seis años vemos como todo un simbolismo ya se manifiesta de forma muy activa en sus primeros dibujos donde mana todo un mundo interior intentando redescubrir su "Yo" más profundo al igual que hacía el hombre de la antigüedad. Según Sri Aurobindo, Bergson ya colocaba la intuición por encima del intelecto y la filosofía alemana reconoce la existencia de facultades suprarracionales y un orden de verdades suprarracionales. El proceso de génesis y producción de la obra plástica, estaría por tanto vinculada a la facultad creadora del ser humano, valorándose la fantasía y el genio como unos dones innatos en el individuo creativo. Toda obra, pone en juego tensiones entre sus elementos y para penetrar en ella, es necesario seguir las vicisitudes a través de las cuales la materia se subordina o impone a una forma que, a su vez, es portadora de significados. El niño desde los dos 
años en muchos casos ya desarrolla parte de estos símbolos en sus primeros dibujos. El inconsciente humano encierra todas las formas de vida y de funciones heredadas de la línea ancestral, de suerte que en cada ser humano nacido preexiste una disposición psíquica funcional adecuada, anterior a la consciencia haciéndose sentir su presencia y su actividad en la vida infantil a través de estos primeros grafismos.

August Macke en el manifiesto del expresionismo alemán llamado El Jinete Azul (Der Blaue Reiter) escribe:

Oír el trueno significa sentir su misterio. Entender el lenguaje de las formas significa estar más cerca de su misterio, vivir. ¿Acaso los niños no son creadores que crean directamente a partir del misterio de sus emociones, mucho más que los imitadores de las formas griegas? ¿Acaso los salvajes no son artistas que tienen sus propias formas, poderosas como el sonido del trueno, un trueno en el que cada flor y cada fuerza se expresa en forma $)^{5}$

La proyección fue una de las raíces del arte, siendo un recurso muy usado por los niños estudiados que suelen imaginar formas en las nubes, los troncos de árbol o las rocas sintiendo fascinación por estas manifestaciones de la naturaleza donde la mente infantil proyecta su imaginación. El artista prehistórico realizaría sus formas a partir de las sensaciones sugeridas por el entorno natural, siendo la materia un valor en sí misma así en Altamira un grupo de bisontes policromados del techo de las cavernas surgiría a partir de las formas naturales de la piedra que el artista contorneó para resaltar la figura. E. H. Gombrich señala como el arte rupestre no sería cualquier cosa menos primitivo, siendo un estilo ya muy desarrollado donde la proyección será una constante en la creación de arte:

Y sin embargo, la prioridad de la proyección pudo seguir determinando el carácter del estilo. A menudo hemos visto en qué grado el punto de partida del artista determina el producto final. El esquema sobre el que se basa una representación seguirá transparentándose a través de la elaboración última. Sería tentador suponer que el rasgo más notorio del arte de las cavernas, su falta de rigidez geométrica, puede relacionarse así como sus distantes raíces en formas indeterminadas, descubiertas y elaboradas por sucesivas generaciones. (1997, pp. 92-93) 
En el arte contemporáneo es muy usual resaltar las formas y texturas que ofrece la naturaleza, buscando la propia expresión natural. En escultura los artistas se dejan seducir por el grano y la textura de los materiales empleados, concediendo gran importancia a las características de la piedra o la madera, intentando extraer la natural esencia del medio. De esta manera siempre hubo artistas que han vislumbrado formas aprisionadas en la materia o en el propio paisaje, formas que ellos como artistas debían de esforzarse por liberar y presentar a la luz de la conciencia como ya ocurriera en el arte prehistórico, en el Renacimiento con Miguel Ángel hasta llegar al siglo XX, donde surge una nueva concepción del arte que no buscaba crear sobre la base de lo racional, sino emular las fuerzas germinales del entorno y adoptar las formas que le proporcionarán las formas erosivas de los elementos. Tal vez el origen del arte puede estar en estas similitudes que nos llevarían a la sombra proyectada por los objetos, animales y el propio hombre la silueta obscura sería el primer paso en la representación del mundo plástico. E. H. Gombrich decía: "Para el primitivo, el tronco de árbol que parece un animal puede convertirse en una suerte de animal." (1997, p. 90)

A finales de los años treinta, Bárbara Hepworth produjo algunas de sus esculturas más rigurosamente simplificadas, consistiendo varias de ellas en una columna aislada de mármol suavemente redondeada o delicadamente tallada para realzar su origen figurativo orgánico. Después de la segunda guerra mundial, realizó una serie de churingas o tótems, emparejados, que evocan los menhires neolíticos de Cornualles. Para el artista moderno, al igual que las sociedades antiguas y primitivas, las piedras sin labrar tenían un significado simbólico, ya que se creía con frecuencia que las piedras bastas y naturales eran moradas de espíritus o de dioses estos artistas intentaron extraer el alma de la piedra tallándola en función de la forma que ésta sugería. En muchos casos esta forma era una aproximación, más o menos definida a la figura humana como podemos apreciar en los antiguos menhires, los Hermes nacidos de las piedras de los linderos en la Antigua Grecia o los primitivos ídolos de piedra. Esta concepción primitiva de la fuerza mágica de la piedra está relacionada también con las piedras preciosas que en distinta épocas se les atribuyeron facultades mágicas y medicinales. El tema de la transmutación de la piedra aparece frecuentemente en las leyendas peruanas y colombianas y podría estar vinculado con el culto paleolítico de las piedras anímicas de los churingas al igual que ocurre con los menhires u hombres de piedra de la cultura megalítica que se extienden hasta el archipiélago del Pacífico. 
En Cornualles (Inglaterra) se ha encontrado dos grandes piedras circulares junto con unos monolitos neolíticos, ambas losas se hallaron puestas de pie. La más grande llamada tolven tiene un agujero de cuarenta y un centímetros de diámetro abierto en el centro, la más pequeña llamada Menetol se ha empleado supersticiosamente para curar niños enfermos haciéndolos pasar por la abertura. Tal vez Henry Moore se inspira en ellas para realizar algunas de sus obras que nos recuerdan la magia de esta época primitiva. El agujero sería símbolo de la abertura a lo desconocido, sería como la espera o la repentina revelación de una presencia. De un agujero abierto en el cráneo de Zeus por un hachazo asestado por Hefaistos, sale la diosa de la inteligencia, Atenea.

Este arquetipo estaría ligado a los símbolos de la fertilidad en el plano biológico, y de la espiritualización en el plano psicológico así en la India se interpreta el agujero como el órgano femenino por donde pasa el nacimiento al mundo y al mismo tiempo sería la puerta del mundo, por donde la muerte permite escapar a las leyes terrenas. El Pi chino, disco de jade que tiene un agujero circular en el centro, sería un símbolo del cielo. Henry Moore decía de esta expresión escultórica:

El primer agujero hecho en un trozo de piedra es una revelación.

El agujero conecta una parte con la otra, haciéndolo inmediatamente más tridimensional.

Un agujero puede tener en sí mismo tanto significado de contorno como una masa sólida. ${ }^{6}$

La materia seria transformada por el niño mediante un proceso que a veces puede resultar arbitrario y experimentado de acuerdo a ciertos presupuestos pálidos débiles e insuficientes, pero en el proceso, el niño al igual que el artista conecta con ideas primordiales que habitan en el interior del ser humano. Entre las figuras de bulto redondo realizadas en barro por los niños vemos numerosos ejemplos donde aparecen formas horadadas y perforadas por los mismos palillos de modelar en forma de círculo, sugiriendo la antigua forma de obtención del fuego mediante rotación. Existe una tendencia general a establecer un paralelismo entre la obtención de fuego mediante el barrenamiento y la sexualidad, poniendo el ejemplo del canto del Rigveda (III, 29, 1-3) que dice: "Es el madero giratorio; el procreador está pronto, trae a la dueña de la tribu. Hagamos girar a Agni a la antigua usanza." (C. G. Jung, 1995, p. 417) 
C. G. Jung (1990), señala como la importancia de la materia se manifiesta ante todo en la elección de la imagen de Dios en la piedra, esta elección aparece en la más antigua alquimia griega. La piedra se ha representado como lugar ocasional de nacimiento de los dioses como la piedra donde nace Mithra. La relación del lapis con la inmortalidad se establece desde épocas muy tempranas. Desde la prehistoria la piedra tiene espíritu. C. G. Jung dice de este arquetipo:

Es la panacea, la medicina catholica (la medicina universal), el alexipharmakon (antiveneno), la tintura que transmuta el metal en oro y el guijarro sin valor en piedra preciosa. Es lo que trae riqueza, poder y salud; como remedio del alma vence a la melancolía, y en un estadio superior, como un vivus lapis philosophicus, es un símbolo del Salvador, del anthropos y de la inmortalidad. Esta incorruptibilidad de la piedra se manifiesta también en la representación antigua, según la cual el cuerpo de los Santos se volvió como piedra. (1990, p. 45)

Desde muy pequeños los niños recogen de la naturaleza distintos tipos de piedras atraídos por sus texturas o color P. Teilhard de Chardin buscaba con seis o siete años alguna piedra, la más transparente o la mejor coloreada:

... cristales de cuarzo o de amatista y relucientes fragmentos sobre todo la calcedonia; lo que me era posible encontrar en la zona. En este último caso era, naturalmente, necesario que la sustancia preciada fuera resistente, inalterable iy dura!

Proceso imperceptible, pero que debía tener inmensa importancia en el curso de mi evolución espiritual, porque justamente gracias a la salida abierta a mis titubeos por la sustitución del Hierro por el Cuarzo en los vastos edificios del Planeta y de la Naturaleza, comencé, sin darme cuenta, a acceder verdaderamente al Mundo, hasta no poder gustar ya nada que no tuviera las dimensiones de lo Universal. (2002, p. 21)

Henry Moore se siente atraído por las formas de los guijarros erosionados que le sirven de inspiración:

Hay formas universales a las que todo el mundo está condicionado subconscientemente y a las que se puede reaccionar, si nuestro control consciente no las rechaza. 
Los guijarros muestran la forma en que la naturaleza trabaja la piedra. Algunos de los guijarros que recojo están atravesados por agujeros. Además de la forma humana me entusiasman tremendamente todas las formas naturales, como la formación de las nubes, los pájaros, los árboles y sus raíces y las montañas, que para mí son las arrugas de la superficie de la tierra, como pliegues. Es extraordinario como se parecen las ondas de la arena en la playa a las marcas de la gubia en el tallado de la madera.?

El arte de Henry Moore nunca es preconcebido o programado sino más bien el resultado de un proceso de conocimiento y experimentación graduales, sería como él mismo definiría "una expresión del significado de la vida, un estímulo al mayor esfuerzo de vivir." ${ }^{8}$. En otras aclaraciones suyas dice: "La observación de la naturaleza es parte de la vida de un artista, aumenta su conocimiento de las formas, le mantiene fresco y le protege de trabajar solamente con fórmulas y alimenta su inspiración." 9 El cuerpo humano, los animales, los huesos, las piedras, y las rocas son los modelos de Moore para la formación de un organismo plástico, para el "hacerse" de una escultura.

\section{EI Inconsciente y la Evolución de la Consciencia Respecto al Arte}

Los arquetipos existen y actúan en el arte, estas representaciones pueden variar muchísimo en detalle sin perder su modelo básico, siendo factores dinámicos que se manifiestan en impulsos teniendo su propia iniciativa y su energía específica que percibimos cuando experimentamos la peculiar fascinación que los acompaña, actúan como fuerzas creadoras que inspiran nuevas ideas. C. G. Jung decía que en el arte plástico ocurre lo mismo con la mano que maneja el lápiz de dibujo, el palillo de modelar o el pincel.

... lo que en última instancia decide es un oscuro impulso, un a priori empuja a configurar y no se sabe que la consciencia de otro es conducida por los mismos motivos; se tiene entonces el sentimiento de estar entregado a una contingencia subjetiva sin límites. Sobre todo el procedimiento parece flotar una presciencia, no sólo de la configuración sino también de su sentido. (1994, p. 148) 
Estas experiencias y consideraciones nos hicieron constatar que existen ciertas condiciones inconscientes colectivas que actúan como reguladores y propulsores de la actividad creadora de la fantasía y que, al poner al servicio de sus fines el material existente en la consciencia, producían las configuraciones correspondientes. Las artes plásticas alimentan el espíritu humano, integrando contenidos inconscientes que totalizan al hombre psíquico, produciendo consecuencias muy importantes como difíciles de describir. Ni siquiera C. G. Jung exponiendo este tipo de cuestiones respecto a la psicología pudo exponer adecuadamente las transformaciones que sufre el sujeto bajo la influencia del proceso que denominó "de individuación". Este suceso consistiría en hacer conscientes partes inconscientes de la personalidad, no produciéndose una simple asimilación de las mismas a la personalidad del yo ya existente, sino más bien se da una transformación de ésta. La afluencia de contenidos inconscientes vivifica y enriquece la personalidad, la voluntad como energía disponible, se subordina a la nueva estructura integrada, denominada por $\mathrm{C}$. G. Jung, "sí-mismo". La individuación significaría por lo tanto llegar a ser un ente singular, traduciéndose como la realización del sí-mismo o la realización de sí. La totalidad consciente es una afortunada unificación del yo y el símismo en la cual ambos mantienen sus características esenciales. El sí-mismo sólo tendría un sentido funcional cuando puede actuar como compensación de una consciencia del yo, si el yo se disolviera identificándose con el símismo surge como bien dice C. G. Jung una especie de "vago superhombre". El proceso de individuación sería el comienzo de un camino evolutivo, que debe tomar el ser humano, ya que, no excluye al mundo, sino que lo incluye, pues el sí-mismo abarca en sí infinitamente mucho más que un mero yo, tal como se puede apreciar en el simbolismo desde siempre.

C. G. Jung descubrió arquetipos del sí-mismo que también hemos hallado en el quehacer plástico del niño de dos a siete años, a través de técnicas como el dibujo sobre papel que permite la improvisación y el juego con la materia. Estas figuras incipientes contienen ya un rico material de fantasía, donde vemos un sinnúmero de complicadas configuraciones que se repiten y que coincidían con otras que C. G. Jung ya había estudiado con sus pacientes en el campo de la forma dramática, dialéctica, visual, acústica, de baile, pictórica, de dibujo o plástica, descubriendo mediante estos métodos el proceso inconsciente al que dio el nombre de proceso de individuación. Otro hecho coincidente en la configuración de estas manifestaciones artísticas fue la aparición de productos mitológicos, comprobándose que los niños de tales obras al igual que los pacientes de C. G. Jung tenían conocimientos de mitología que 
eran sobrepasados por sus creaciones de la fantasía configuradora. Lo que demostraría de modo inequívoco la coincidencia de las fantasías regidas por reguladores inconscientes con las manifestaciones de la actividad espiritual humana en general, conocidos por la tradición e investigación etnológica.

Sri Aurobindo nos habla de una sociedad que habiendo comenzado a espiritualizarse, haría de la revelación y la realización del Ser divino en el hombre el objetivo primordial de todas sus actividades, su educación, su conocimiento, su ciencia, su ética, su arte, su estructura económica y política:

En el arte, la sociedad espiritualizada no le asignaría como única misión la representación de imágenes del mundo objetivo y del mundo subjetivo, sino la de contemplar estos mundos con la visión significativa y creadora que traspasa las apariencias y revelan la Verdad y la Belleza, cuyas formas o apariencias, cuyos símbolos o imágenes significativas, son las cosas visibles e invisibles. (2002, p. 289)

C. G. Jung descubrió que esta simbología perteneciente a las más antiguas tradiciones sagradas que se repite en todas las culturas, estaría relacionada con los periodos de transición en la vida del individuo. Serían símbolos de transformación que están demandando la necesidad de liberarnos del estado actual en el que nos encontramos buscando en nuestra vida la transcendencia. Esta función de la consciencia sería la plena realización del potencial del símismo individual, los arquetipos señalarían el camino que debe buscar el hombre para su liberación para este autor el yo consciente estaría subordinado al sí-mismo que constituiría el centro de la personalidad psíquica total que sería ilimitada e indefinible, no susceptible de formulación y sólo simbólicamente expresable, constituyendo la totalidad del ser humano, tanto en lo consciente como en lo inconsciente. El sí-mismo se expresaría como una fuerza particular en cada hombre impulsándolo a la individuación y realización de su propia existencia. El sí-mismo trabajaría como una energía que apunta hacia una totalidad, donde el yo estaría subordinado al sí-mismo e iría más allá de sus valores e ideas, pudiendo incluso ir contra ellas, pues el sí-mismo enfrentaría al hombre constantemente a un camino de cambio y reevaluación. 


\section{Los Arquetipos Primitivos: Su Relación con la Actividad Plástica de los Niños y los Artistas del Siglo XX}

En el quehacer plástico de un niño se pueden ver a lo largo de su infancia, símbolos e imágenes que no permanecen estáticos, sino que cambian, evolucionan y gradualmente van desarrollando ciertos temas inconscientes o arquetipos. Hacia los dos años comienzan a dibujar sus primeros grafismos siendo siempre formas circulares que abarcan todo el papel, o conjuntos de círculos. El trazo gestual será muy importante en los niños al igual que hicieron los prehistóricos mediante líneas de expresión el artista conecta con su interior, Hans Arp apuntaba sobre esta forma de trabajar:

Entonces, con los párpados entornados, el movimiento interior fluye inmaculado hasta la mano. En una habitación oscura es aún más fácil seguir la guía del movimiento interior que al aire libre. Un director de música interior, el gran diseñador de las imágenes prehistóricas, trabajaba con la mirada vuelta hacia dentro. Así sus dibujos ganan en transparencia; se abren a la interpretación, a la inspiración repentina, a la recuperación de la melodía interior, a la aproximación circular, y la totalidad se transmuta en una gran exhalación. ${ }^{10}$

El empleo de formas sin relación directa, con ningún objeto real será una forma de expresión importante en los artistas del siglo XX aquí los niños también tienen una tendencia hacia los símbolos abstractos, estos símbolos pueden ir acompañados de objetos transformados como hicieran en su obra Klee, Kandinsky o Miró entre otros, siendo estos artistas los primeros que buscaron esta libertad primitiva en sus obras, tal vez por ello nos recuerde al arte infantil en sus primeras etapas. En sus obras no hay arriba ni abajo, como tampoco existe distinción o separación clara entre un objeto y otro. Los niños, como estos creadores, hacen un empleo continuo de la superposición sin normas de escala o proporción de tamaños (Fig. 1), representando a menudo gran variedad de símbolos como ya hiciera el hombre prehistórico. Así en los dibujos infantiles en sus primeros inicios, en torno a los dos o tres años, se caracterizaran por la ausencia de fondo, al igual que la concepción prehistórica del espacio, donde todas las direcciones lineales poseen igual derecho, cualquier inclinación respecto a la horizontal es permisible en los 360 grados. (Fig. 2) 

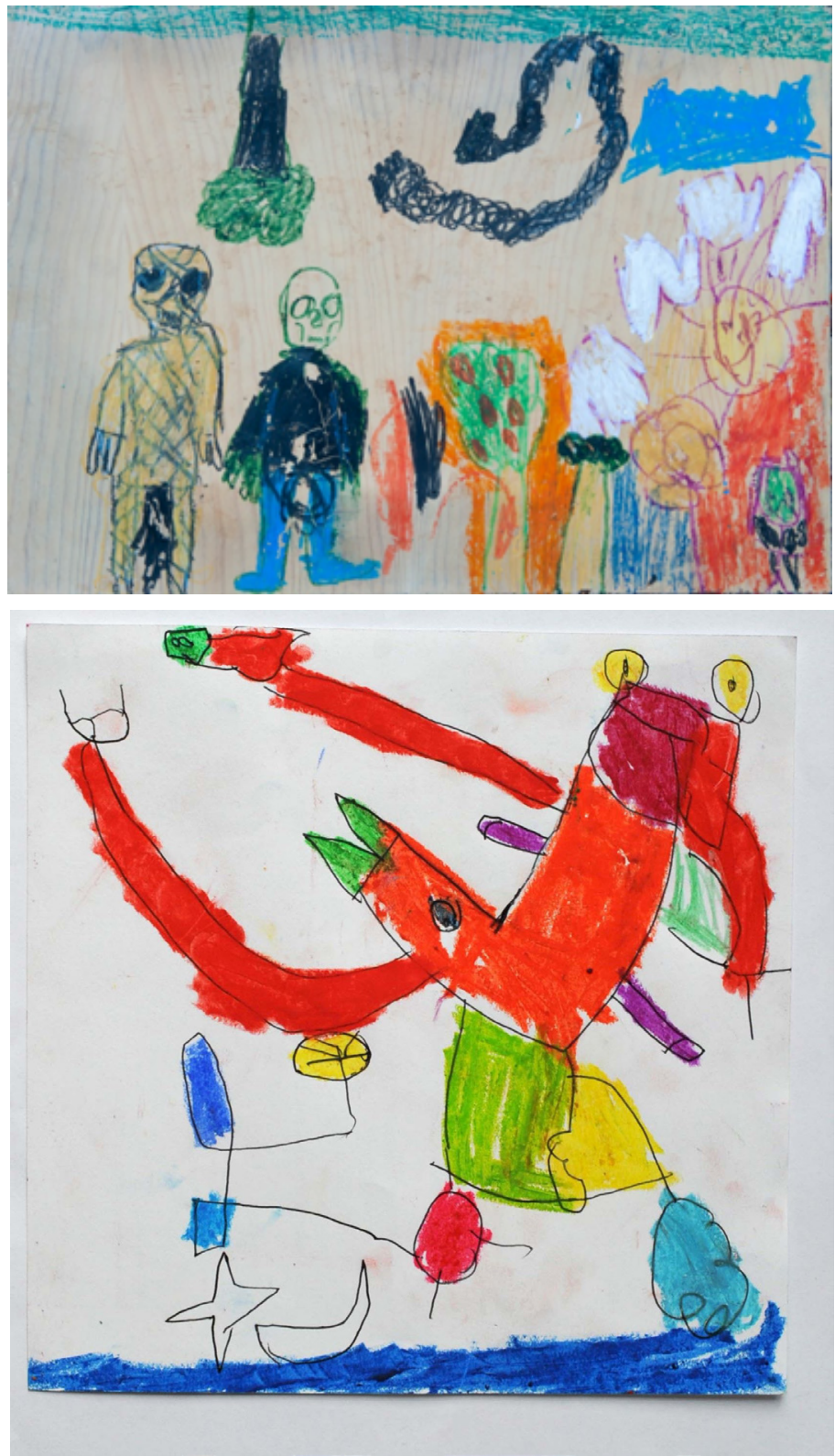

Figura 1. Dibujo niño de 7 años. (C)

Figura 2. Dibujo de niño de 4 años. (C) 
En estos primeros grafismos infantiles hemos encontrado paralelismos con la simbología del arte prehistórico así en el arte primevo naturalista del período

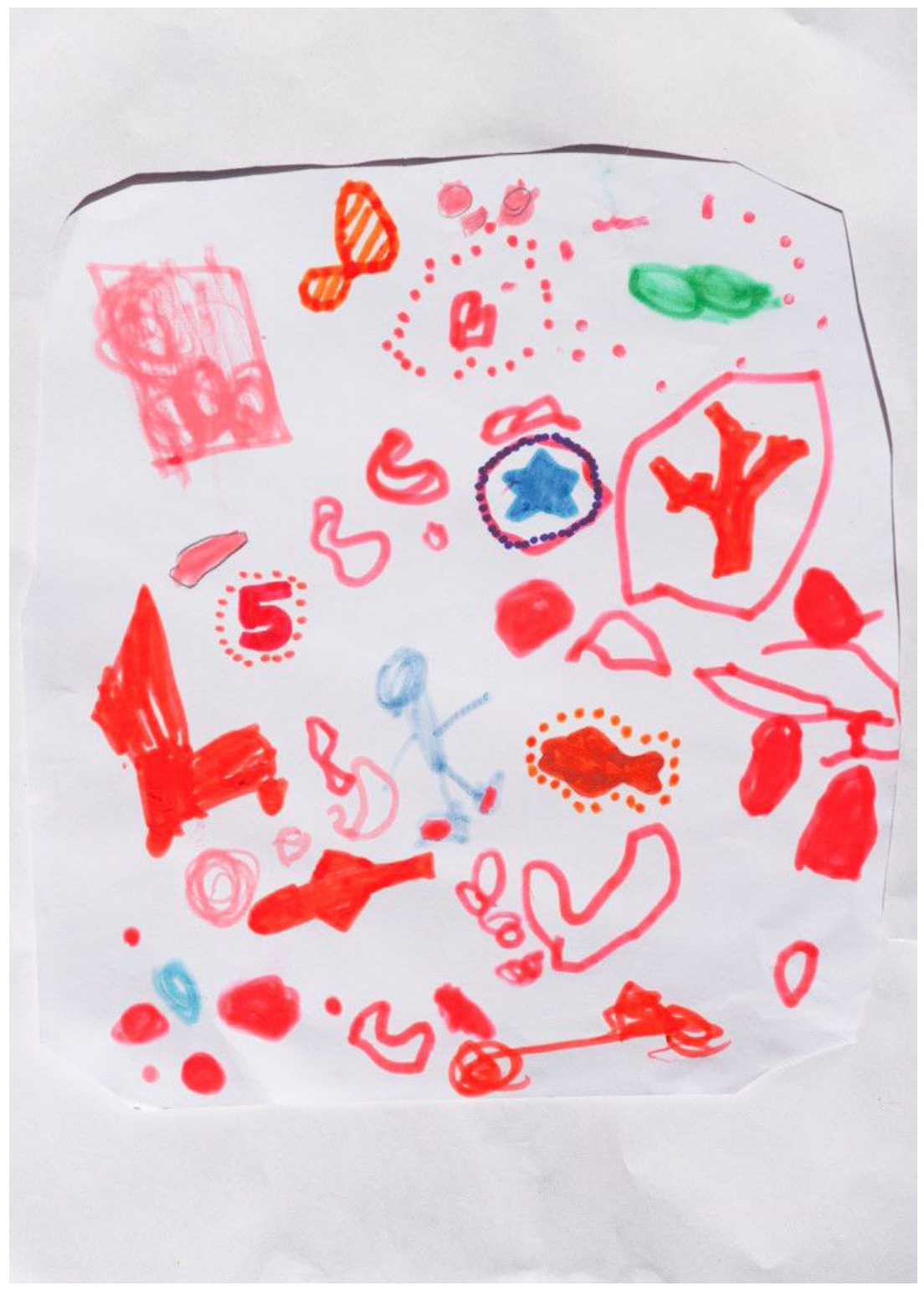

Figura 3. Dibujo niño de 7 años. (C) 
magdaleniense, el tipo más usual de abstracción sería aquel que concentra y simplifica la forma natural; y en un segundo lugar aquel que emplea formas (Foms and Shapes) inexistentes en la naturaleza y a las que se ha dotado de un significado simbólico conocido solamente por los iniciados. Mientras que un tercer tipo consistiría en mezclar temas naturales transformados con símbolos abstractos. En un cuarto tipo la concentración y simplificación se lleva tan lejos que los rasgos naturalistas se pierden por completo, en el periodo auriñaciense se encontrarán ejemplos de este tipo de abstracción, siendo en las últimas fases de la Edad del Bronce y los comienzos de la del Hierro cuando se llega a su total representación. Este último tipo de abstracción según S. Giedion, también se dará en el arte de la década comprendida entre 1910 a 1920 muchos artistas eliminaran el detalle, dando más fuerza a su obra. Los niños usarán este recurso de forma permanente en sus primeros dibujos incipientes realizados a los dos años, hasta la formación de símbolos más concretos a los seis y siete años. (Fig. 3)

En estas primeras etapas de la vida el niño representará con mucha frecuencia los arquetipos relacionados con el tema de la madre y la fecundidad que son también muy recurrentes en el mundo del arte. Para C. G. Jung el "anima" sería la madre que tendría dos aspectos, uno constructivo y otro destructivo la madre, es por un lado la seguridad, el alimento, el amor y el cobijo frente a una madre devoradora y castradora. Esta ambivalencia se correspondería con el mar y la tierra, en el sentido de que una y otra son receptáculos y matrices de la vida. El mar y la tierra son símbolos del cuerpo maternal. Nacer es salir del vientre de la madre, morir es retornar a la tierra. La madre es el abrigo, el calor y la ternura, siendo también por el contrario, el riesgo de opresión debido a la estrechez del medio y al ahogo por una prolongación excesiva de la función nodriza y de guía. Las grandes diosas madres han sido diosas de la fertilidad como Gea, Rea, Hera, Deméter para los griegos, Isis entre los egipcios y en las religiones helenísticas, Ishtar entre los asirobabilonios, Astarté para los fenicios e íberos y Kali entre los hindúes.

Los niños dibujan el arquetipo del hijo formándose en el útero de la madre mediante el procedimiento que los antropólogos denominan "radiografía" al referirse al arte primitivo. Los artistas contemporáneos al igual que los niños representan una imagen simultánea del interior y el exterior al mismo tiempo, para ello muestran el objeto como si fuera trasparente, delineando el contorno y representando después el interior. (Fig. 4 y 5) 

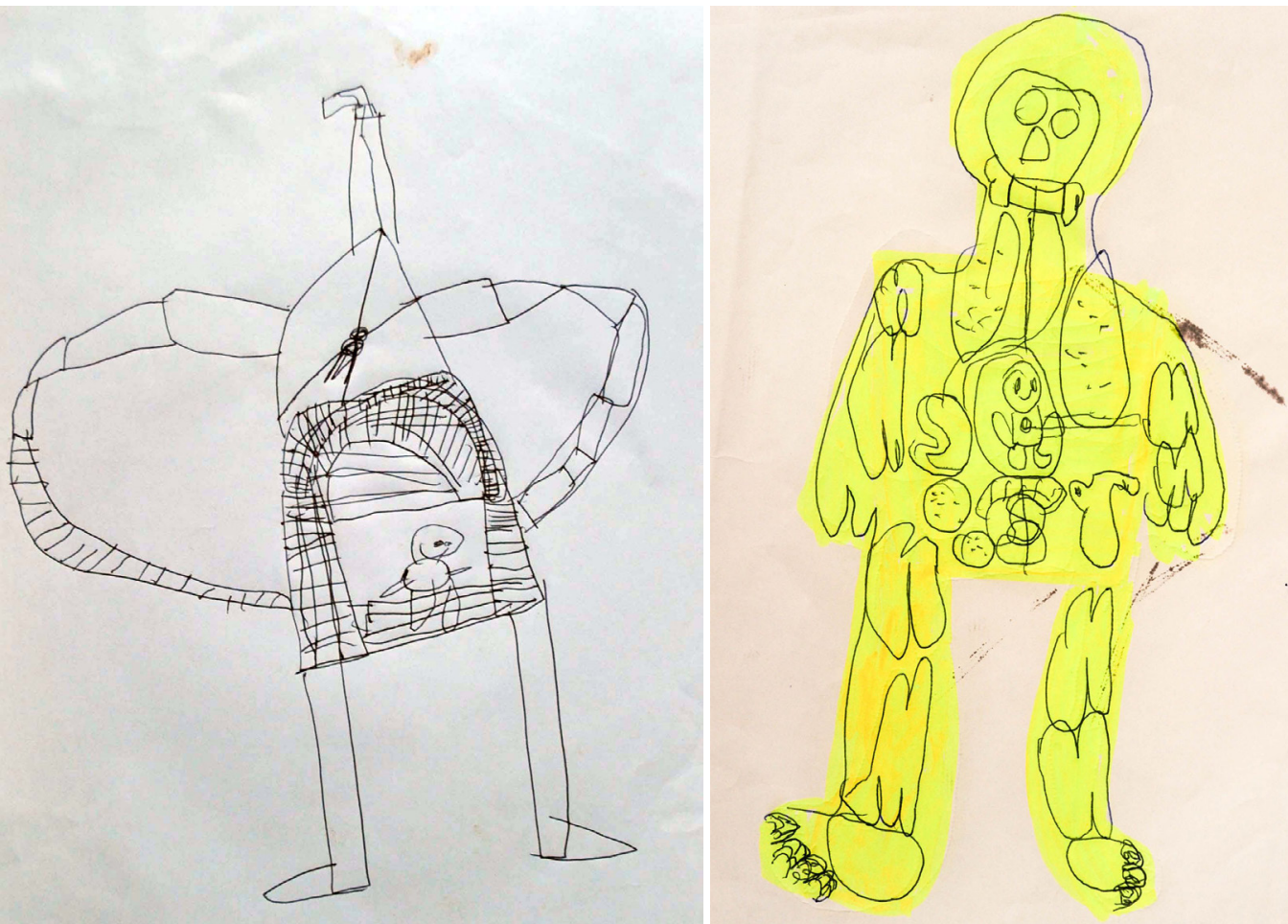

Figura 4. Hijo formándose en el útero de la madre, dibujado por un niño de 4 años.(C) Figura 5. Hijo formándose en el útero de la madre, dibujado por un niño de 5 años.(C)

El niño no reproduce a veces el objeto real que éste tiene ante sí, sino que lo interpreta al igual que los artistas contemporáneos, mostrando únicamente elementos invisibles de este objeto y al mismo tiempo es posible que otros que saltan a la vista sean enteramente desdeñados. El erudito francés G. H. Luquet en su obra L'art primitif (1930) compara metódicamente el significado de los dibujos infantiles, del arte primitivo y del arte prehistórico diciendo: "Para el hombre de hoy, una pintura es comparable cuando reproduce lo que sus ojos ven; para el hombre primitivo lo es cuando expresa lo que su mente sabe." 11 
Paul Klee, en su dibujo Getroffenes Muttertier (1923) usa este recurso de la trasparencia para representar un animal saeteado mientras sus crías hambrientas buscan sus ubres para alimentarse. Marc Chagall pintará este mismo tema de la madre, en Retrato de Vava de 1966, donde vemos una mujer con una abertura oval trasparente en su regazo que contiene una pareja de novios besándose como preludio de fecundidad.

La copa tiene que ver con el seno materno que produce la leche, en la India la copa de oblación del soma se asimila al creciente lunar, el soma sería el bálsamo de la inmortalidad. El grial medieval, sería otro arquetipo ligado a la copa, el cáliz de la última cena que recogió la sangre de Cristo, la búsqueda de éste simboliza la aventura espiritual, tiene que ver con dos talismanes de la religión céltica precristiana el caldero de Dagda y la copa de soberanía para C. G. Jung, simbolizaría la plenitud interior tan buscada por los hombres. E. Pérez de Carrera lo interpreta en este mismo sentido:

Puede que la sangre sagrada, el Grial que buscaban los caballeros de Arturo, no fuera la copa del Galileo crucificado en Jerusalén sino un misterioso estado de consciencia que proponía una búsqueda interior, y sólo los caballeros, las gentes que juraban lealtad, sacro-oficio, entrega, generosidad y defensa de los débiles podían pretender semejante hazaña. $(2004$, p. 85)

Las manos han sido representadas como símbolos mágicos en la prehistoria mediante impresiones en relieve sobre arcilla o imágenes directas de manos pintadas sobre la superficie parietal con ayuda de colores, en positivo o negativo. S. Giedion describe dos técnicas:

a) Impresión positiva: la mano se recubre de color rojo o negro y se aplasta contra la superficie pétrea, encontrándose en los repliegues de roca de las cavernas en color ocre, rojo y en manganeso azul-negro.

b) Impresión negativa: se coloca la mano contra la pared de piedra, y se extiende o se sopla el color alrededor de los contornos de los dedos y la planta.

En los niños se pude observar en edades muy tempranas la utilización de las dos técnicas descritas, se untan las manos con tempera y las plasman sobre el papel o bien colocan la palma de la mano sobre el papel contorneando luego con una línea la silueta de la mano. (Fig. 6) 


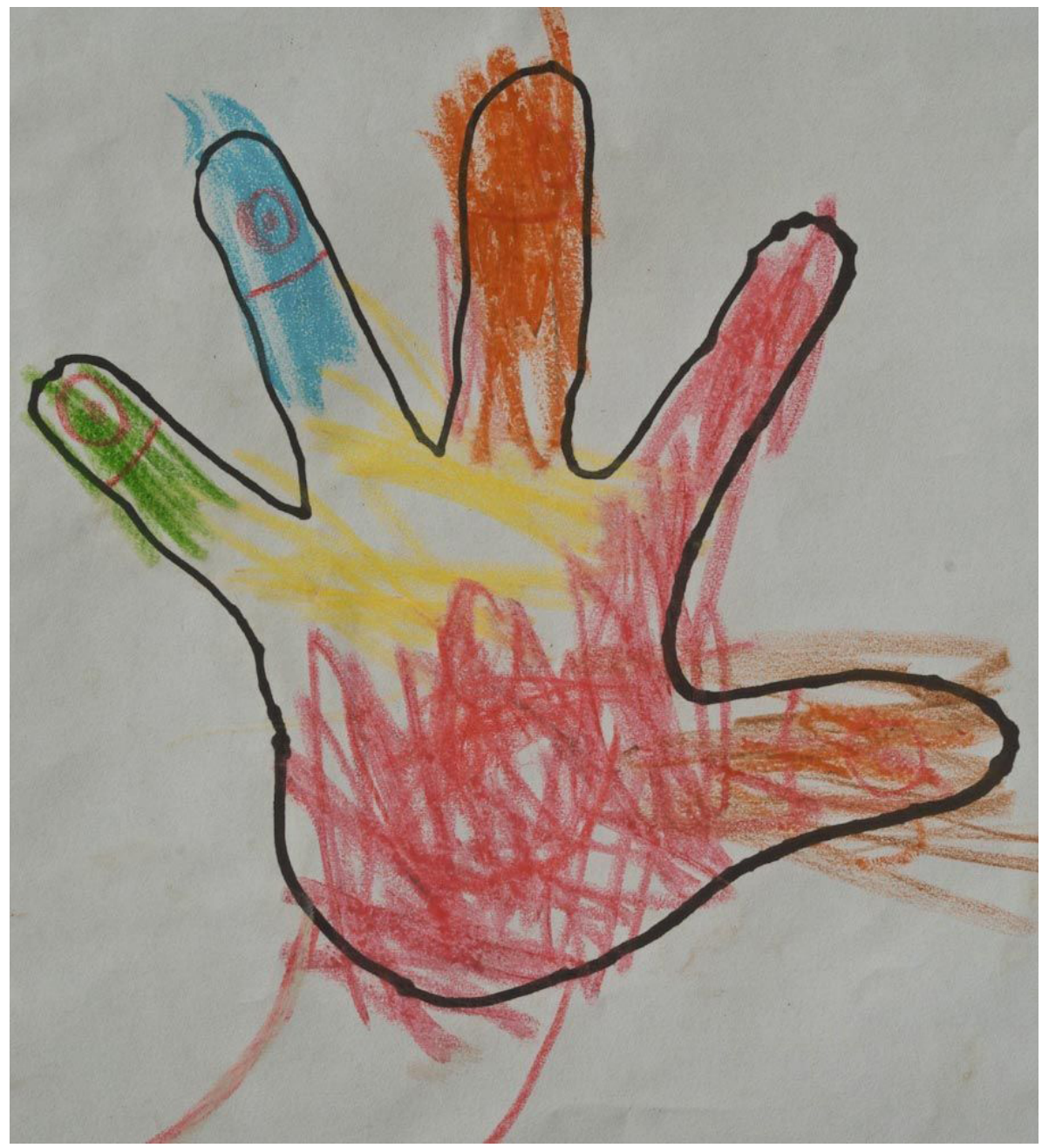

Figura 6. Palma de la mano sobre el papel contorneando la silueta. (Dibujo de un niño de 7 años). (C)

S. Giedion nos dice acerca de este símbolo: "En las culturas más dispares de las cuatro partes del mundo aparecen manos provistas de significado simbólico. Lo más que tienen en común es su afinidad humana: rara vez puede apreciarse otra vinculación directa con ellas.” (1991, p.122) 


\section{Conclusiones}

Toda esta simbología del niño tiene su importancia en su desarrollo, por lo que no debemos desdeñarla, nuestros métodos de enseñanza deben ser menos restrictivos, preocupándonos principalmente por estimular su creatividad y que trabaje sobre sus propias experiencias lúdicas y emocionales, donde busque temas de expresión con un alcance ilimitado.

Como vemos, el niño al nacer traería consigo un cerebro heredado de los antepasados que sería el resultado orgánico de la función psíquica de todos los ascendientes en el estarían preformados los instintos, todas las imágenes primordiales que han constituido siempre el fundamento del pensar humano y todo el tesoro de los temas mitológicos en toda su insospechada variedad, el niño produciría a veces combinaciones de ideas y símbolos, que no cabe atribuir a las experiencias de su existencia individual, sino más bien a la historia del espíritu humano.

El modo de pensamiento primitivo, analógico, del sueño y el mismo quehacer artístico recrean estas antiguas imágenes del inconsciente que aparentemente creemos están causadas por nuestra consciencia y sin embargo poseen su propia realidad y espontaneidad. La comprensión de esas imágenes, surgidas de lo más hondo de la psique es de vital importancia en la problemática del proceso del devenir de la personalidad del ser humano, siendo el arte una fuente importantísima en la aportación de símbolos.

\section{Notas}

${ }^{1}$ Autor citado por E. H. Gombrich, La preferencia por lo primitivo. Episodios de la historia del gusto y el arte de Occidente, Ed. Debate, Londres, 2002, p. 149.

2 Autor citado por E. H. Gombrich, La preferencia por lo primitivo. Episodios de la historia del gusto y el arte de Occidente, Ed. Debate, Londres, 2002, p. 264.

3 S. Giedion, El presente eterno: los comienzos del arte, Col. Alianza Forma $n^{\circ} 16$, Ed. Alianza Editorial, Madrid, 1991, p. 120.

${ }^{4}$ Autor citado por E. H. Gombrich, La preferencia por lo primitivo. Episodios de la historia del gusto y el arte de Occidente, Ed. Debate, Londres, 2002, p. 261.

5 Autor citado por E. H. Gombrich, La preferencia por lo primitivo. Episodios de la historia del gusto y el arte de Occidente, Ed. Debate, Londres, 2002, p. 224.

${ }^{6}$ Autor citado por D. Mitchinson. Henry Moore. Escultura, Ed. Polígrafa, Barcelona, 1981, p 46. 
${ }^{7}$ Autor citado por D. Mitchinson, ibídem, p. 26.

${ }^{8}$ Autor citado por D. Mitchinson, ibídem, p. 7

${ }^{9}$ Autor citado por D. Mitchinson, ibídem, p. 25.

${ }^{10}$ Autor citado por S. Giedion, ibídem, p. 81.

${ }^{11}$ Autor citado por S. Giedion, 1991, p. 74.

\section{Referencias}

Aurobindo, Sri. (2002). El ciclo humano. Barcelona: Fundación Centro Sri Aurobindo.

Giedion, S. (1991). El presente eterno: los comienzos del arte. Madrid: Col. Alianza Forma $\mathrm{n}^{\circ} 16$, Alianza Editorial.

Gombrich, E. H. (1997). Arte e ilusión. Estudio sobre la psicología de la representación pictórica. Madrid: Debate.

Gombrich, E. H. (2002), La preferencia por lo primitivo. Episodios de la historia del gusto y el arte de Occidente, Madrid: Debate.

Jung, C, G. (1990). Psicología y simbólica del arquetipo. Barcelona: Col.

Biblioteca de Psicología Profunda no 29, Paidós.

Jung, C. G. (1994). Arquetipos e inconsciente colectivo. Barcelona: Col.

Biblioteca de Psicología Profunda $n^{\circ}$ 14, Paidós.

Jung, C.G. (1995). Los complejos y el inconsciente. Madrid: Alianza.

Jung, C. G. (1996). Recuerdos, sueños, pensamientos. Barcelona: Col.

Biblioteca Breve, Seix Barral.

Mitchinson, D. (1981). Henry Moore. Escultura. Barcelona: Polígrafa.

Pérez de Carrera, E. (2004). 49 Respuestas a la aventura del pensamiento, tomo I. Madrid: Fundación Argos.

Teilhard de Chardin, P. (2002). El corazón de la materia. Santander: Col. "El pozo de Siquen"139, Sal Terrae. 
Belén León Río: Profesora Titular Interina del Departamento de Escultura e História de las Artes Plásticas. Universidad de Sevilla.

Contact Address: Facultad de Bellas Artes. C/Laraña n³, CP 41003, Sevilla.

E-mail address: belenleon@us.es 
Instructions for authors, subscriptions and further details:

http://brac.hipatiapress.com

\section{El Arte como Resistencia. La Ópera-Tango María de Buenos Aires}

Carlos L. Bosch ${ }^{1}$

1) Universidad Nacional de las Artes, Buenos Aires. Argentina

Date of publication: February $3^{\text {rd }}, 2015$

Edition period: February 2015 - June 2015

To cite this article: Bosch, C.L. (2014). El Arte como Resistencia. La Ópera-Tango María de Buenos Aires. Barcelona, Research, Art, Creation, 3(1), 59-72. doi: 10.4471/brac.2015.04

To link this article: http://dx.doi.org/10.4471/brac.2015.04

\section{PLEASE SCROLL DOWN FOR ARTICLE}

The terms and conditions of use, except where otherwise noted, are related to the Open Journal System and to Creative Commons Attribution License (CCBY). The indication must be expressly stated when necessary. 


\section{Art as Resistance. The Opera- Tango Maria of Buenos Aires}

Carlos L. Bosch

National University of Arts

(Received: 7 November 2014; Accepted: 7 Desember 2014; Published: 3 February 2015)

\section{Abstract}

On the shores of tango have landed large amount of literary and musical influences. Since its inception goer until the golden age, in the years 40 , the different orchestras were incorporating aesthetic of each period at the same time that were reflected in the great social changes of the twentieth century. In spite of this, the vast majority of the tangueros felt that Astor Piazzolla had crossed a boundary, had gone too far with his work, Maria de Buenos Aires. Not only is the first opera-tango of history, but that is one of the jobs where better reflects the differences and disputes toward the interior of the tango. While this work arises in an era where the artistic avant-gardes influenced the art scene in Buenos Aires, the defenders of the tango as traditional music of the city did not want to lose certain traditions that this gender jealously guarding her. We will analyze to what extent this work implies a resistance to the established conceptions of his time and how that resignification involves a series of changes that go beyond the tango.

Keywords: Tango, opera, resistance, Piazzolla, art 


\section{El Arte como Resistencia. La Ópera-Tango María de Buenos Aires}

Carlos L. Bosch

Universidad Nacional de las Artes

(Recibido: 7 Noviembre 2014; Aceptado: 7 Diciembre 2014; Publicado: 3 Febrero 2015)

\section{Resumen}

En las orillas del tango han desembarcado gran cantidad de influencias musicales y literarias. Desde su inicio prostibulario hasta la época de oro, en los años 40, las diferentes orquestas fueron incorporando estéticas de cada período al mismo tiempo que se hacían eco de los grandes cambios sociales del siglo XX. A pesar de ello, la gran mayoría de los tangueros consideraron que Astor Piazzolla había cruzado un límite, había ido demasiado lejos con su obra, María de Buenos Aires. No sólo es la primera ópera-tango de la historia sino que es uno de los trabajos donde mejor se reflejan las diferencias y disputas hacia el interior del tango. Si bien esta obra surge en una época donde las vanguardias artísticas influían en el panorama artístico de Buenos Aires, los defensores del tango como música tradicional de la ciudad no querían perder ciertas tradiciones que este género custodiaba celosamente. Analizaremos hasta qué punto esta obra implica una resistencia a las concepciones establecidas de su época y cómo esa resignificación involucra una serie de cambios que van más allá del tango.

Palabras clave: Tango, ópera, resistencia, Piazzolla, arte 


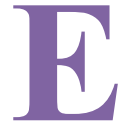

n 1956, Cátulo Castillo y Aníbal Troilo componen el último gran clásico del tango tradicional, La última curda, y ese mismo año Astor Piazzolla edita su primer éxito, Tres minutos con la realidad. Tal vez este sea el mejor símbolo, la fotografía donde se puede observar el momento donde un tango que ya estaba de vuelta se cruza con el tango de la renovación. Comenzaba una época de cambios y gran presencia de las vanguardias en todo el arte argentino. Declaraciones como la de Luis Felipe Noé, "es hora de elaborar nuestras propias vanguardias" (Giunta, 2001) o Aldo Pellegrini (1967), "-la vanguardia- contribuiría a sacudir la modorra un poco provinciana que aquejaba a nuestro arte", son una muestra de la impronta vanguardista que se vivía en Buenos Aires.

Piazzolla pertenece a una época donde se hacen difusos muchos límites, entre ellos, la diferencia tajante entre música popular y académica. George Gershwin en el jazz o Antonio Jobim en la Bossa Nova, llevaron adelante intentos similares y tuvieron que enfrentarse a los mismos prejuicios y críticas. Adiferencia de las vanguardias, ellos no se vanagloriaban de generar una ruptura o de cortar con las tendencias del pasado, por el contrario, querían modificar lo establecido sin romper con el género, sin dejar de ser Jazz, Bossa o Tango. Así, Piazzolla logró combinar una orquesta clásica con un Bandoneón, la armonía moderna con los ritmos arrabaleros y las formas instrumentales clásicas con la canción popular.

A partir de los años 60, Astor ya adquirió la experiencia suficiente como para romper los moldes de ambos mundos. Comienza a componer tangos para Orquesta de Cámara, para Cuartetos de Cuerdas y también una Ópera, María de Buenos Aires. Horacio Ferrer, en el año 65, le entrega el libreto de lo que llamaba Tango-Operita cuyo argumento relata la vida del tango desde su nacimiento, pasando por su infancia, la adolescencia multicultural, el esplendor de los grandes teatros, la decadencia, la muerte y, finalmente, su resurrección en el "nuevo tango". Encontró el discurso que le iba a permitir sostener la unión entre tradición y vanguardia pero también entre lo académico y lo popular. Gilles Deleuze (1987) afirma que el arte es un acto de resistencia y propone como ejemplo a Johann Sebastian Bach. En el siglo XVIII, la división de lo sensible proponía una separación absoluta entre lo sacro y lo profano. Bach fusiona estas dos instancias generando lo que Deleuze llama un acto de resistencia. Se resiste a aceptar el mundo establecido y propone una nueva mirada. Bach nos grita desde la historia su oposición a una partición insalvable entre lo 
sacro y lo profano. Piazzolla adopta la misma postura frente a las dicotomías de su época. Se resiste y propone una nueva división de lo sensible donde no hay separación entre lo académico y lo popular o la tradición y la vanguardia.

Las distintas miradas que vamos a desarrollar sobre María de Buenos Aires, se van a estructurar y van a contribuir con esta idea de acto de resistencia, concepto central a la hora de pensar la primera Opera-tango de nuestra historia.

\section{La Resistencia al Interior del Campo}

Dos días después del estreno, el diario La Nación (Anónimo, 1968) publicó la siguiente crítica referida a María de Buenos Aires:

Sobre un pretexto dramático se estructura este ejercicio musical en la que domina la inconfundible modalidad de Piazzolla - él mismo interpreta el bandoneón - y donde Horacio Ferrer - el propio narrador - desgrana una retórica casi inaprehensible, hecha de neologismos emparentados con el lunfardo. (p.71)

Cuarenta años después, el mismo diario (La Nación, 2008) decía lo siguiente:

A cuarenta años de su creación, la operita vive un gran momento y no deja de girar por el mundo. Ya pasó por unas cien ciudades y en la historia de la dupla formada por Piazzolla-Ferrer -una sociedad artística que duró veinte años- la ópera María de Buenos Aires es una de sus obras más interpretadas. Remediando esa larga deuda con la obra de Piazzolla-Ferrer, este año se realizarán dos estrenos locales de la operita. (p.2)

En estas dos críticas se hace patente el largo proceso de legitimación por el que tuvo que atravesar la ópera. Partiendo de una crítica soportada en la incomprensión de la obra hasta llegar al culposo reconocimiento de una deuda histórica con el artista. Pero las relaciones de fuerza que resultaron de esa disputa sólo se nos van a hacer visibles analizando la confrontación. Únicamente estudiando las posiciones, acciones, estrategias e instituciones involucradas podremos dimensionar las tensiones provocadas por esta 
resistencia.

Para tal fin, Pierre Bourdieu (1967) brinda un efectivo marco teórico que nos permitirá analizar las distintas posiciones frente al capital simbólico para luego determinar las relaciones de fuerza que surgieron en el interior del campo. Analicemos las diferencias entre lo que se da en llamar Tango tradicional y la propuesta de Piazzolla.

Para comenzar, en ambos estilos se legitiman valores diferentes. La tradición, el sonido, la rítmica tradicional -aferrados al tango de los años 40y la aceptación muy excepcional de algunos cambios -como los de Horacio Salgán- eran valores del tango tradicional. También se defendían las prácticas sociales de la milonga, el prestigio basado en la popularidad y la fuerte relación entre los integrantes de la orquesta, entre la orquesta y su público y entre la orquesta y su barrio de origen. Por el contrario, Piazzolla sostenía los valores de la evolución basada en dos justificaciones: la idea de enaltecer la cultura popular elevando su música y la decadencia que el tango sufría desde los años 50. Se reconocen viejos valores del tango pero sin aferrarse a ellos. El prestigio provenía de su alto nivel técnico y el éxito en el exterior. En este sentido, la ópera-tango es uno de los casos más representativos.

Uno de los grandes problemas que enfrentó Astor tuvo que ver con la falta de aceptación en las instituciones legitimadoras del género. También en este punto se ven diferencias importantes. Para el tango tradicional, el espacio por excelencia era la milonga pero igualmente se tocaba en clubes de barrio y en los carnavales. En términos mediáticos tenían presencia en la Radio -programas de tango o musicales-, muy poco en televisión y se habían publicado revistas de tango en los años 40 y 50 pero los 60 ya no se editaban. Las discográficas financiaban sobre todo programas de radio. Las más importantes del tango eran RCA Víctor, Odeón y Columbia. Se producía a medida que el público demandaba. La demanda se medía desde la radio y las disquerías. Piazzolla, a raíz de su nueva concepción y del rechazo por parte de este circuito, tuvo que desenvolverse en otro tipo de instituciones. Prefirió presentarse mayormente en teatros. Dentro de los medios tenía más presencia en los medios gráficos -suplementos culturales de diarios y revistas- y poca presencia en radio y televisión. Cada tanto se pasaba algún tema por la radio porque para ciertos programas significaba prestigio, como en Radio Nacional y Clásica. Hasta el año 69 no firmó con ninguna de las discográficas típicas del tango, tuvo que grabar con las de otros géneros: Phillips, La Trova y Polydor. Por ejemplo, María de Buenos Aires se grabó en La Trova. Tenía poco alcance nacional pero mucho impacto en el exterior. 
Desde ya, al defender diferentes valores, circuitos de difusión y concepciones del tango, los hábitos también eran disímiles. En las orquestas tradicionales, el director era la figura: Di Sarli, Darienzo, Troilo, Pugliese. Los ingresos de esas orquestas provenían básicamente de tres ámbitos: actuaciones en clubes, venta de discos y los derechos de autor por la reproducción de su música en radio y tv. Tanto las entradas como los discos tenían un precio superior al del resto de la música popular. Un músico podía durar muchos años tocando en una orquesta. La relación era laboral pero también personal -como si fuera un grupo de amigos-. Incluso en los peores momentos económicos, los directores de las orquestas se preocupaban para que sus músicos -los muchachos- no se queden sin trabajo. Algo fundamental es la prioridad que se le daba al baile y a la canción. Un buen tango, además de tener una buena melodía, tiene que poder bailarse. Se utilizaba la forma canción y los cantantes se especializaban en tango -eran cantantes de tango-. Las letras de las canciones utilizan un lenguaje poético aunque directo, tocando temas como el amor, la vida cotidiana o la realidad social.

En la renovación del tango las cosas se movían de una forma muy diferente. El instrumentista y compositor era la figura -Piazzolla, Salgán, Garello, Stampone-. Piazzolla tuvo varias formaciones: Quinteto, octeto, orquesta de cuerdas, etc. La relación con sus músicos se daba desde las necesidades compositivas -quinteto, octeto electrónico, etc- y laborales -contratos por el tiempo que duraba una gira-. Utilizaba la forma canción pero también incorporó estructuras clásicas como la Fuga, la Sonata, la Ópera etc. Los cantantes no provenían del tango -Susana Rinaldi, Amelita Baltar, Teresa Parodi- y los textos tienen una gran carga simbólica -en María de Buenos Aires llegan al surrealismo-. La mayor parte de los ingresos provenían de las giras y las ventas de discos en el exterior. Piazzolla, comenzó a venderse en Argentina luego del 68 con Balada para un loco aunque no lo hizo en forma sostenida. En este punto, al igual que el tango tradicional, los discos y las entradas para verlo eran caras en comparación con los precios de la música popular en general. El espacio donde más se nota la disputa con el tango tradicional es en el hecho de que Piazzolla sienta al público a escuchar tango, no se bailaba, y las melodías, todas instrumentales hasta el 68 , no eran fáciles de cantar.

La relación con el campo político fue sinuosa en ambos casos. Entre 1890 y 1920 el tango era prohibido en muchos ámbitos por chabacán. De 1930 a 1948 se censuran algunos tangos por deformar el idioma. Luego se dieron las prohibiciones políticas -Di Sarli por radical, Pugliese y Salamanca por 
comunistas, Hugo del Carril por peronista, etc-. Piazzolla sufrió censuras de presidentes de facto -Lanusse y Videla- por relacionarlo con las vanguardias que, a su vez, eran relacionadas con un supuesto pensamiento de izquierda y distorsiones al ser nacional.

Como pudimos observar, Piazzolla -y María de Buenos Aires en particulardiscute las reglas del campo en todos los aspectos: producción, distribución y consumo. Busca un cambio de mentalidad basado en una modernización de la estética tanguera, una idea de público donde el tango deja de ser una experiencia colectiva para disfrutarse en forma íntima y una concepción evolucionista del arte que tal vez haya dejado su rastro en parte de las generaciones posteriores pero que claramente todavía no estaba legitimada en los años 60 .

Esta ópera es el soporte material de una concepción que ya funciona como una apuesta en las luchas realizadas en ese campo de producción pero que aún no ha sido legitimado por sus instituciones -teatros, discográficas, medios de comunicación, público específico, etc-. Por lo tanto no ocupa una posición dominante y su resistencia queda expuesta al intentar redefinir los principios de dominación y legitimación del campo.

\section{La Resistencia en la Cultura}

A finales de los años 50, el sentimiento de post-guerra se hizo carne gracias al boom tecnológico, económico y cultural de la época, a raíz de lo cual, la ideología dominante pasó a ser el progreso. Se torna inevitable el trajín de las grandes ciudades, aumenta el acceso a medios de transporte, se afirma la televisión como el gran medio de comunicación y la juventud nace como grupo político, universitario y de consumo.

Puntualmente, en las fechas que rodean al estreno de María de Buenos Aires (mayo de 1968), se respira el cambio y la revolución. La Primavera de Praga en Checoslovaquia, París se agita con el Mayo Francés, la Guerra de Vietnam continúa su trágico curso, el cineasta Stanley Kubrick estrena 2001: odisea del espacio y The Beatles publican su polémico Álbum blanco.

Para Antonio Gramsci, las grandes transformaciones sociales son obra del hombre colectivo. Cuando el sistema entra en crisis surge la necesidad de construir una nueva voluntad colectiva que será el agente efectivo de la transformación social y funcionará como matriz de sentido. El nuevo proyecto comienza una guerra de posiciones donde buscará afirmarse como hegemónico. Tomando las propias palabras de Gramsci (1970): 
(...) todo acto histórico tiene que ser realizado forzosamente por el "hombre colectivo", es decir, presupone la existencia de una unidad "cultural-social" que junta para un mismo fin una multiplicidad de voliciones disgregadas, con la heterogeneidad de fines, sobre la base de una misma concepción del mundo. (pp. 20-21)

Ahora bien, si existe una resistencia es porque primero se había instalado una supuesta "normalidad". ¿Cómo se instala esa norma en la sociedad? Michael Foucault analiza el término a-normal (en su libro Los anormales) en torno a las cuestiones del saber y del poder. Considera que existe un "poder de normalización" que se ejerce a través de una serie de tecnologías de control. Esto es lo que permitirá la aparición, en consecuencia, de sujetos a-normales (los que no coinciden con la norma). Siguiendo esta misma idea podemos entender que la norma estética o la estética como disciplina normativa, ha actuado históricamente como parte del discurso hegemónico. Gracias a esto, la estética llega a la enseñanza en las academias, a los medios de comunicación y al resto de los aparatos institucionales característicos de cada momento económico y social cerrando así el trinomio de norma-saberpoder (Foucault, 1974):

Y, por último, creo que el siglo XVIII introdujo, con las disciplinas y la normalización, un tipo de poder que no está ligado al desconocimiento sino que, al contrario, sólo puede funcionar gracias a la formación de un saber, que es para él tanto un efecto como una condición de su ejercicio. (p.59)

Esos valores estéticos dominantes que se presentan como "normales", simplemente son el fruto de un contexto muy específico donde los metadiscursos del arte forman parte de la ideología dominante. Tomando el caso de Beethoven, observemos cómo algunos críticos de la época calificaron a su séptima sinfonía. De la Guarda (1986) publicó en su libro Las sinfonías de Beethoven, la siguiente crítica:

Música absurda y salvaje. El colmo de la deformidad. Un delirio donde no hay el menor rasgo de melodía ni armonía, ni un solo sonido que sea agradable al oído. Luego de esta sinfonía, deberían encerrar a Beethoven en un manicomio. (p.265) 
En ese contexto, la ideología dominante sostenía una norma estética la cual calificaba tanto a Beethoven como a su obra de "a-normal". Esta objetivación pasa a formar parte del "sentido público" de la obra y de la definición propia del creador.

Pero no se puede decir que esos conflictos sean de una clase social contra otra o de un sector contra otro. Son cambios que cruzan a toda la sociedad. Las clases y sectores interactúan y hacen muy complejas sus relaciones. Todos los grupos terminan influyendo sobre todos. ¿Cómo se articulan todas esas contradicciones y diferencias? Gramsci responde que es la ideología quien las regula y mantiene dentro del sistema. Ese es el espacio, el de la articulación, donde se da la lucha y la transacción, las victorias y las derrotas. Ahí se generan las correlaciones de fuerza entre las distintas concepciones y es por eso que todo hecho cultural es un hecho político. Parte de este proceso es expuesto por Gramsci (1999) de la siguiente forma:

Un tercer momento -de la conciencia colectiva- es aquel en que se alcanza la conciencia de que los propios intereses corporativos, en su desarrollo actual y futuro, superan el circulo corporativo, de grupo meramente económico, y pueden y deben convertirse en intereses de otros grupos subordinados. Esta es la fase más estrictamente política, que señala el tránsito neto de la estructura a la esfera de las superestructuras complejas, es la fase en la que las ideologías germinadas anteriormente se convierten en "partido", entran en confrontación y se declaran en lucha hasta que una sola de ellas tiende a prevalecer (...). (pp. 36-37)

El progreso tecnológico y la vanguardia artística forman parte de esa cultura dominante que intentaba articular los grandes cambios. En ese sentido, Piazzolla y los tangueros de la renovación formaban parte de un movimiento cultural más amplio que buscaba afirmarse como dominante. Ya comentamos al principio de este trabajo el hecho de que Piazzolla no busque la ruptura sino un vínculo que relacione el pasado del tango con su futuro -al igual que lo hicieran Gershwin o Jobim-. Toda obra, y María de Buenos Aires en particular, son la prueba del intento por articular distintos sectores de la cultura, por articular la vanguardia con la tradición, lo académico con lo popular o la Buenos Aires de los barrios con la del centro. Esta ópera es un símbolo, es una obra donde se logra materializar con mayor claridad esos valores y visones del mundo y, por lo tanto, donde queda expuesto este enfrentamiento por una nueva forma de producción, circulación, consumo y conducción del género. 


\section{Las Marcas de la Resistencia}

Lo político en el arte no sólo puede encontrarse en una proclama política concreta sino en su propuesta estética. La ruptura de la unidad de sentido dominante es, tal vez, el efecto político más profundo al que puede alcanzar una obra. Jacques Rancière (2005) entiende que la configuración de un nuevo espacio es lo político del arte:

Efectivamente, la política no es en un principio el ejercicio del poder y la lucha por el poder. Es ante todo la configuración de un espacio específico (...) la política es el conflicto mismo sobre la existencia de ese espacio, sobre la designación de objetos que comparten algo común y de sujetos con una capacidad de lenguaje común. (p.18)

En nuestro caso, la pregunta sería ¿Cuáles son, en María de Buenos Aires, las características que nos llevan a esa nueva división de lo sensible, a la ruptura en la unidad de sentido? No nos interesa tanto analizar las relaciones de fuerza que pudieran haber transformado la obra a posteriori sino las que actúan directamente en el momento de su concepción.

Para explicar este punto voy a utilizar como ejemplo a Frédéric Chopin. Este compositor no componía un preludio en abstracto que luego adaptaría a las ideas del romanticismo, Chopin componía directamente desde el romanticismo, con toda la red de ideas filosóficas, morales, políticas y estéticas que esto significa. Su obra es la materialización de esas ideas. Por lo tanto, las características estéticas de una obra y las características que luego supondrán una resistencia son las mismas. ¿Cuáles son las características del sonido Piazzolla? o dicho de otra forma ¿En qué puntos María de Buenos Aires es la materialización de una resistencia al consenso establecido? Para eso analizaremos las características de la obra desde su concepción.

Una de las primeras características que llama la atención es la utilización de la ambigüedad. Piazzolla forja una resignificación de elementos del tango y de la Ópera:

La primera y más obvia de las ambigüedades se encuentra al leer el nombre de los movimientos que componen la obra. Mezcla el lenguaje de la música clásica con el del tango: Tocata Rea, Tangus Dei, Tangata del alba, Fuga y misterio, Miserere canyengue de los ladrones antiguos en las alcantarillas.

Los instrumentos y voces utilizados son: orquesta de cuerdas, flauta traversa, guitarra, bandoneón, cantantes y coro. Esta formación se puede interpretar 
como una orquesta de cámara con bandoneón o como una orquesta de tango con coro. Sostiene la ambigüedad necesaria entre los dos géneros.

Los giros melódicos son claramente tangueros pero su ornamentación es clásica -especialmente Barroca-.

La línea de voz está escrita como para que sea cantada tanto por un cantante de ópera como por un cantante de tango.

Busca tratar temáticas tradicionales del tango como el amor, la traición o la vida de la calle pero sobre un argumento donde los personajes ocupan un rol totalmente simbólico como el porteño gorrión con sueño, la sombra de María, el coro de psicoanalistas o la voz de ese domingo -recursos del surrealismo no utilizado por el tango-.

En el léxico se encuentran giros del arrabal pero utilizando nuevos discursos. Por ejemplo, el tiempo es simbólico. No se puede decir que exista un tiempo del argumento ni un tiempo real. Transcurren en lo que podría ser un tiempo onírico.

Dentro de las novedades que propone esta Ópera, encontramos:

La estructura de la obra no es la de una Ópera clásica ni la de un tema popular. Se estructura en 2 actos compuestos de 8 canciones cada uno. Este esquema puede pertenecer tanto a la ópera antigua de Monteverdi -siglo XVII- como a los modernos musicales de Broadway.

Otro caso lo encontramos en la armonía. Utiliza progresiones de acordes típicas del Barroco pero con tipos de acordes provenientes del Jazz o el clásico contemporáneo -al estilo de Bartok-.

Utiliza frecuente del Riffs y Ostinatos típicos de la música popular del siglo XX.

Acordes tonales que se forman por cuartas -la melodía está en el bajo y los acordes por cuartas se escuchan en un registro más agudo-.

Genera colores armónicos típicos del impresionismo pero utilizando las funciones tonales del Jazz.

Entre el explícito simbolismo de los personajes y los permanentes monólogos dirigidos al público, se busca que la audiencia no entre en el juego de la ficción. Lo importante no es la identificación con los personajes sino con la historia.

Como podemos ver, esta ópera-tango fue concebida resignificando elementos de ambos mundos e introduciendo nuevas ideas de la vanguardia -tanto popular como clásica-. Ostenta una nueva designación de los objetos y la capacidad de generar un nuevo lenguaje en común entre los sujetos. Claramente abre un nuevo espacio político -en términos de Rancière- ya que 
se resignifica los elementos que la componen como la melodía, armonía, orquestación, personajes, estructura de la obra, léxico, etc- construyendo una nueva mirada sobre su mundo.

\section{Conclusiones}

En una entrevista realizada en Chile por Gonzalo Saavedra (1989), tres años antes de su muerte, Astor define esta obra como "música popular de cámara que viene del tango". Tal vez sea este el mejor ejemplo del concepto gramsciano de que la cultura no es homogénea ni sistemática sino el resultado de una compleja interacción entre grupos sociales. Los horizontes personales $\mathrm{y}$ colectivos se fusionan.

Como pudimos ver hasta ahora, los distintos géneros y estilos se influían unos a otros. De la decadencia del tango en los años 50 surge la propuesta de Piazzolla que, a su vez, estaba influenciada por las ideas de la vanguardia musical pero desde una concepción evolucionista que provenía de la música clásica. La ópera María de Buenos Aires parece tener el mismo origen caótico y contradictorio que su protagonista: "Diosa y atorranta, del cielo y del hampa fue trampa lo mismo, y atados de un pelo van su parte de cielo y su parte de abismo".

La famosa frase de Paul Klee (1964), "El arte no reproduce lo visible, hace visible", nunca estaría mejor aplicada que en este caso. En los años 30 y 40 el tango había hecho visible la vida cotidiana de vastos sectores sociales pero los años 60 necesitaban ser representados de otra forma. Las rupturas del arte no eran menos fundamentales que las sociales. El arte logró renombrar, reconceptualizar, resignificar, reorganizar y al hacerlo, ayudó a posicionar al sujeto en un lugar distinto al que el rol social le había predestinado. Al hacerlo, la obra se convirtió en un acto de resistencia. 


\section{Referencias}

Anónimo (1968, 10 de Mayo), Novedad Musical de Piazzolla y Ferrer, La Nación, 71.

Bourdieu, P. (1967), Campo intelectual y proyecto creador, Problemas de estructuralismo, México, Siglo XXI.

De la Guarda, E. (1986), Las sinfonías de Beethoven. Su historia y su análisis, Buenos Aires, Ricordi Americana S.A.E.C.

Deleuze, G. (1986), ¿Qué es el acto de creación?, Revista Fermentario, 6, 15.

Foucault, M. (1974), Los anormales, Buenos aires, Fondo de Cultura Económica.

Giunta, A. (2001), Vanguardia internacionalismo y politica, Buenos Aires, Paidos.

Gramsci, A. (1970), Introducción a la filosofía del a praxis, Barcelona, Ediciones Península.

Gramsci, A. (1999), Cuadernos de la Cárcel. Edición crítica del Instituto Gramsci, México, ERA.

Gramsci, A. (2004), Los Intelectuales y la Organización de la Cultura, Buenos Aires, Nueva Visión Argentina.

Klee, P. (1964), Schöpferische Konfession, Das Blindnerische Denken, Stutgart, Basel

Plaza, G. (2008, 6 de febrero), La obra de Piazzolla y Ferrer vuelve a renacer, La Nación, Sección Espectáculos, 2.

Pellegrini, A. (1967), Panorama de la pintura argentina contemporánea, Buenos Aires, Paidos.

Rancière, J. (2005), Sobre politicas estéticas, Barcelona, Servei de Publicacions de la Universitat Autónoma de Barcelona.

Saavedra, G. (1989, julio), Astor Piazzolla: Un tango triste, actual, consciente, El Mercurio, 42. 
Carlos L. Bosch: Universidad Nacional de las Artes.

Contact Address: Yerbal 1642, Ciudad Autónoma de Buenos Aires, Argentina.

E-mail address: carlosbosch73@gmail.com 
Instructions for authors, subscriptions and further details:

http://brac.hipatiapress.com

\section{Adventure Series de Tracey Moffatt y la TV Star}

María V. Caro Cabrera ${ }^{1}$

1) Facultad de Ciencias de la Educación. Universidad de Málaga. España

Date of publication: February $3^{\text {rd }}, 2015$

Edition period: February 2015 - June 2015

To cite this article: Caro Cabrera, M. (2014). Adventure Series de Tracey Moffatt y la TV Star. Barcelona, Research, Art, Creation, 3(1), 73-88. doi: 10.4471/brac.2015.05

To link this article: http://dx.doi.org/10.4471/brac.2015.05

\section{PLEASE SCROLL DOWN FOR ARTICLE}

The terms and conditions of use, except where otherwise noted, are related to the Open Journal System and to Creative Commons Attribution License (CCBY). The indication must be expressly stated when necessary. 


\section{Tracey Moffatt's Adventure Series and the TV Star}

María V. Caro Cabrera

University of Málaga

(Received: 30 June 2014; Accepted: 24 November 2014; Published: 3 February 2015)

\section{Abstract}

This research project explores the structural, conceptual and aesthetic ties that Tracey Moffatt's Adventure Series (2004) has to TV series. The paper arrives at three basic conclusions. First, by sequencing images Moffatt provides a temporal and episodic dimension to the plot, similar to that of TV series. Second, the main character in both TV series and Adventure Series is an archetype that remains unmodified, despite the progression of time. And third, the serial structure, the redundancy and the anticipation in present in $T V$ series and Adventure Series help the main character support both the narrative and the aesthetic discourse of the piece.

Keywords: Tracey Moffatt, TV series, archetype, intertextuality, narrative 


\section{Adventure Series de Tracey Moffatt y la $T V$ Star}

María V. Caro Cabrera

Universidad de Málaga

(Recibido: 30 Junio 2014; Aceptado: 24 Noviembre 2014; Publicado: 3 Febrero 2015)

\section{Resumen}

Esta investigación se realiza en torno a la obra de Tracey Moffatt Adventure Series (2004) y a los vínculos estructurales, conceptuales y estéticos que le unen al serial televisivo. Deducimos de estas conexiones tres principios básicos: primero, que la secuenciación de sus imágenes aporta una dimensión temporal, episódica, al argumento que de ellas se supone; segundo, que el protagonista de ambas obras -del serial y de Adventure Series- es un arquetipo que se mantiene claro, sin las distorsiones que pudiera acarrearle el acontecer; y tercero, que es este personaje el que sostiene, junto a la estructura serial, la redundancia y la anticipación, tanto el relato de la obra como el discurso estético y plástico que de esta obra se desprende.

Palabras clave: Tracey Moffatt, serial televisivo, arquetipo, intertextualidad, narrativa 
a artista multidisciplinar Tracey Moffatt (Brisbane, 1960) considerada como una de las figuras con más proyección dentro de las artes plásticas australianas-, realiza Adventure Series en el 2004, una obra fotográfica secuencial compuesta por diez piezas, cada una de las cuales combina en sí misma tres fotografías separadas por un espacio en blanco (o gutter), tal y como lo harían las viñetas de un cómic o de una fotonovela -a esas piezas las llamaremos "páginas" por su gran parecido con estos formatos y por la necesidad de diferenciarlas de las imágenes fotográficas que en ellas se insertan. Lo importante de su estructura secuencial, lo que le confiere peculiaridad y lo que la convierten en nuestro objeto de estudio, es que a la hora de su exposición, la autora no requiere que estas páginas respeten su orden numérico. Ciertamente, Moffatt no impone la jerarquía en sus series, además de que, según le comenta a Susan Brigth (2005), "cada pieza formada por tres imágenes es una historia individual” (p. 92). De ello deducimos que no hay vinculación narrativa entre una y otra página -más adelante refutaremos esta proposición.
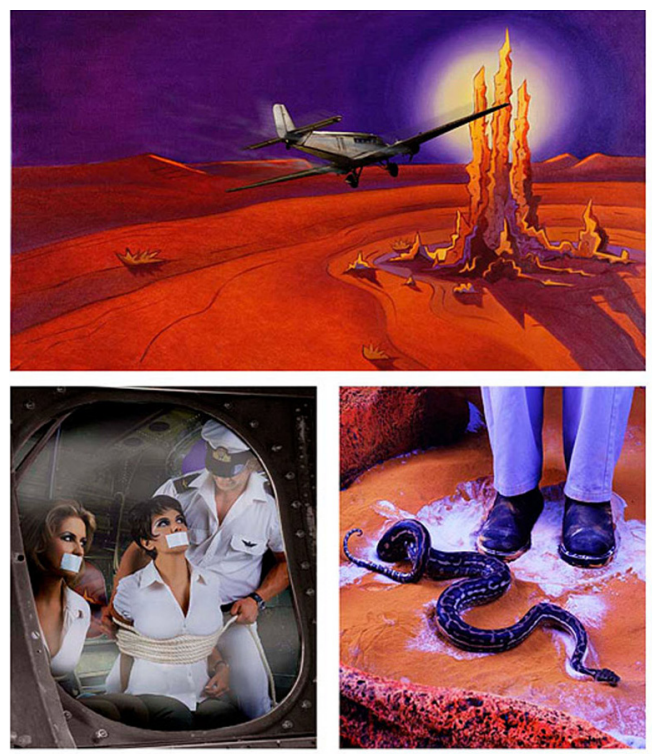

Figura 1. "Adventure Series" 1. (C) 
La estética, iluminación, colorido, disposición escénica y compartimentado de Adventure Series conecta además con la telenovela o la serie de televisión revelándose como un texto serial en tanto que comparte con estos formatos las características que iremos desgranando de intertextualidad, indeterminación, inestabilidad y recurrencia. Utilizaremos por lo tanto este artículo con dos objetivos claros: por una parte para mostrar que Moffatt utiliza las estructuras del serial televisivo para dotar de tiempo a la imagen; para, como dice ella en su conversación con Gerard Matt (1998), "añadirle otras posibilidades" (p. 14) y crear la ilusión de narración -que, por otra parte, transgrede de inmediato en su acepción clásica al suspender indefinidamente el final del supuesto relato. La configuración formal y el conocimiento del código de lectura que ésta implica podría hacernos pensar que, para obtener un significado claro, sólo tenemos que interpretar los signos; llegamos así a nuestro segundo objetivo que no es otro que el de frustrar este axioma y cualquier propuesta teórica que vincule una trama clásica ${ }^{1}$ a la estructura formal de la seriación (es por eso que nos interesa de manera especial esa ruptura de las jerarquías narrativas -basadas en la causalidad- que sucede al no vincular cada página a un orden determinado). Y por último, dilucidaremos qué elementos concretos han hecho falta para que, en el caso de Adventure Series, las estructuras secuenciales no vehiculen una diégesis tradicional y, sin embargo, el discurso estético ocurra precisamente en y por esa indefinición.

La metodología que aplicamos se basa en el análisis textual de la obra desde una perspectiva narratológica, en los paralelismos formales entre las estructuras lingüísticas y, en una extensión del concepto "texto", las estructuras fotográficas seriadas y las de las series televisivas. La manera en la que esta estructura lleva aparejada el devenir temporal nos da pie a revisar los desarrollos narrativos y a cuestionar la idea preconcebida de un maridaje estable entre tiempo y estructura a nivel textual. Dentro de este análisis formal consideramos también el factor estético y ese componente que en Adventure Series carga en sí mismo con todas las posibilidades narrativas: el personaje (prolongación del prototipo televisivo). Realizamos, además, un estudio de los contenidos, para el que nos hacemos eco de referentes televisivos de la propia Moffatt, nos servimos del concepto Bajtiano de intertextualidad, y de recursos de cierta fotografía posmoderna reivindicativa de la ficción, el drama y la producción previa del modelo fotográfico. Como base de este análisis dialógico entre formatos plásticos y mediáticos utilizamos las teorías estructuralistas y postestructuralistas lingüísticas -tomando en cuenta autores como Barthes y Kristeva. En el campo de la estética, el enfoque escogido es 
el de las teorías de la Estética de la recepción ${ }^{2}$ y los Estudios visuales ${ }^{3}$ que apuestan por el proceso de "lectura" de la imagen, y que nos permiten dejar atrás el "giro lingüístico" Mitchelliano (la experiencia está filtrada por medio del lenguaje), enfrentándola a la idea de que la percepción permite un acceso directo a lo sensible cotidiano, eludiendo así la función mediadora del lenguaje.

Comenzaremos el corpus de esta investigación haciendo una leve revisión histórica de la evolución del personaje, elemento que nos será clave para relacionar la serie televisiva con Adventure Series. Desde antes de los años 50 (la época de mayor éxito de la fotonovela), en México ya se utilizaban artistas encumbrados para protagonizar formatos narrativos que combinaban fotografías y relatos, nos referimos más concretamente al foto-drama de Ramón Valdosera Póker de Ases aparecido en 1942 y protagonizado por los ídolos cinematográficos del momento (Curiel, 2001, p. 39), más tarde el flujo de famosos tomará también el camino inverso, propiciando la fotonovela oportunidades a sus actores para dar el salto al cine (Rojas y Cruz Soto, s/f). Los seriales televisivos y las fotonovelas llevaron a sus protagonistas a la fama de tal manera que estas novelas quedaron relegadas a meros documentos que alimentaban el morbo de la vida privada de la diva o el divo que los protagonizaba. Según Jan Baetens (2009), la fotonovela se transforma gradualmente "en lo que podría llamarse un relato fotográfico "disfrazado". [...] Una variación de la fotografía de las grandes estrellas" (p. 240) donde los sucesos que éstos protagonizan ocupan un segundo plano. En estos formatos el personaje está tan unido al actor que lo encarna que en la telenovela mejicana de 1993 Valentina la presión del público obligó a rehacer la obra, a tirar a la basura entre 70 y 100 capítulos ya grabados -capítulos que mostraban un argumento muy distinto a lo que visualmente se relacionaba con la actriz principal (Verónica Castro) y a mostrarla de nuevo encarnando el tipo de personaje que la gente esperaba de ella (Blanca de Lizaur, 1995, p. 133).

Roland Barthes (1977) acota aún más las características de este personaje al compararlo con lo que a él se refiere en la poética aristotélica, la cual lo trata de manera secundaria sometiéndolo irremediablemente a la noción de acción:

El personaje, que hasta ese momento no era más que un nombre, el agente de una acción, tomó una consistencia psicológica y pasó a ser un individuo, una «persona», en una palabra, un «ser» plenamente constituido, aun cuando no hiciera nada y, desde ya, incluso antes de actuar; el personaje ha dejado de estar subordinado a la acción, ha encarnado de golpe una esencia psicológica; estas esencias podían ser 
sometidas a un inventario cuya forma más pura ha sido la lista de los «tipos» del teatro burgués (la coqueta, el padre noble, etc.) (p. 32).

Ciertamente, un par de personajes con una rígida caracterización arquetipal (figuraciones primarias, actualizaciones del mito) aportan en sí mismos todas y cada una de las relaciones posibles que existen entre ellos, por lo que tendrán el poder de evocar una narración, cualquier narración, aún sin pasar a la acción. Este "halo mítico" (Tous, 2010, p. 226) es la base de la recurrencia serial por la que el componente de novedad se ve sustituido por la combinación novedosa de los mismos ingredientes. La permanencia, o sea el contacto con lo mítico, asegura al espectador qué se puede esperar; y el cambio y la novedad garantizan el interés renovado por el producto.

En cuanto al componente temporal de las series, tenemos que diferenciar cualquier sit-com familiar de los años 50 -en las que se reproducían de manera idílica la american way of life y la consecuente felicidad doméstica sin conflictos significativos (Tous, 2010, p. 171), y en las que el tiempo no parece precipitarse hacia ningún final en concreto- de la telenovela, o series del tipo Dallas o Dinasty (Dallasty), en los que la continuidad de la historia y la evolución de los personajes se convierten en centrales (Zunzunegui y Zubillaga, 1988, p. 6).

Nos interesa de manera especial el caso de una serie de corte más dramático que apareció junto a algunas otras cop-shows a partir de 1975, nos referimos a la norteamericana Hill Street Blues ${ }^{4}$ (1980-1987 exhibida por la MBC), y nos interesa porque encontramos en ella un detalle análogo a Adventure Series en su componente temporal. El peculiar desarrollo de Hill Street Blues permite visionar la serie sin atender a una progresión dramática, hasta tal punto que en Gran Bretaña fue proyectada en desorden sin que al parecer acarreará este hecho grandes perjuicios comerciales (Zunzunegui y Zubillaga, 1988, p. 21). La razón esgrimida por Zunzunegui y Zubillaga a esta elasticidad en las conexiones episódicas se basa en que la temporalidad de esta serie es irrelevante con respecto a los aspectos básicos sobre los que está construida -los cuales serían: la oposición exterior/interior, el corporativismo, los limites de lo constitucional, los affaires que se suceden...- Los conflictos, o bien se solucionan en unos pocos capítulos y son de tipo anecdótico, o bien permanecen estancados sin solución, ni avanzan ni retroceden sino que se reproducen a sí mismos. Lo que nos interesa acentuar es que su cronicidad se asienta sobre un modelo estacionario que refuerza "la sensación que se transmite de que nada tiene arreglo" (p.22). Este modelo estacionario 
también queda reflejado en las fotografías de Adventure Series: los personajes protagonizan escenas congeladas en un punto de su desarrollo por la falta de evidentes conexiones entre la imagen posterior y/o anterior (en esto se basa la insubordinación a la jerarquía que impone su orden numérico), además de que estos personajes se multiplican en lo que pudieran ser microrelatos (que no se resuelven y que vienen a sumarse al suspense de su hipotética trama principal).

Otro aspecto temporal de las series digno de mención es consecuencia de su larga duración, secuelas, precuelas y temporadas que se suceden sin descanso: las imágenes y la memoria se van urdiendo con la propia cotidianeidad del espectador. No es difícil que esta unión ocurra en la formación de los recuerdos teniendo en cuenta lo que puede llegar a suponer en la vida cotidiana un serial televisivo periódico y constante -algunos duran decenios (por lo que bien se merecen el adjetivo de culebrón $)^{5}$ y sus personajes envejecen ante nuestros ojos (que envejecen a su par)-, además del hecho de que proporcione a la realidad cotidiana estereotipos morales, de comportamientos y situacionales, añadiendo personajes ficticios a nuestro entorno familiar. Las influencias entre las series y la cotidianeidad del espectador también realizan un cambio de sentido, $\mathrm{M}^{\mathrm{a}}$ Isabel Menéndez (2008) constata lo siguiente: "Los seriales son los productos televisivos que mantienen más relación dialógica con el público ya que es frecuente que se escriban casi simultáneamente a su emisión, de manera que es posible recoger datos de la recepción en el público para incorporarlos a guiones y personajes" (p. 38). Es la identificación ${ }^{6}$ del espectador en el personaje y la aceptación, o no, de las resoluciones ideadas para los problemas planteados en la trama serial, lo que finalmente va moldeando el desarrollo de la ficción televisiva, por lo que, aún no ajustándose este entramado a la cotidianeidad, sí se mueve en los parámetros del deseo constatado del espectador. 

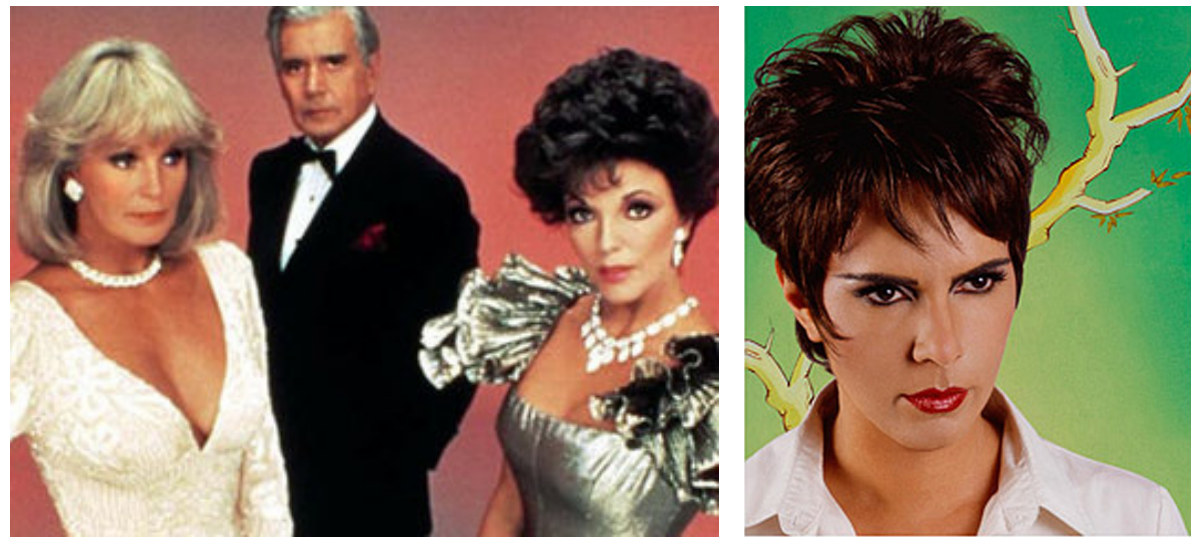

Figura 2. Serie "Dinasty" 1981-1989. (C)

Figura 3. "Adventure Series" 2 (fragmento, autorretrato). (C)

A partir de aquí nos gustaría dejar claras las consecuencias que tienen estos aspectos configuradores de las series -el personaje, la temporalidad, recurrencia y suspense-, en la obra de Moffatt Adventure Series para posteriormente dilucidar sus posibles consecuencias narrativas en la fotografía secuencial. La pertenencia de Moffatt a una generación para la que la televisión ha ocupado un aspecto central en la infancia $-\mathrm{y}$, por supuesto, su interés personal por los formatos televisivos-, hace que los modelos aportados por este medio sean muy abundantes en su obra fotográfica. La idea de la referencia textual como base de la obra plástica sin merma alguna en la novedad de ésta, nos lleva a revisar el concepto de intertextualidad. En "La palabra, el diálogo y la novela”, Julia Kristeva (1978) acuña por primera vez esta noción: “(...) todo texto se construye como mosaico de citas, todo texto es absorción y transformación de otro texto. En lugar de la noción de intersubjetividad se instala la de intertextualidad" (p. 190). Para Kristeva, la intertextualidad ${ }^{7}$ caracteriza a toda la literatura del siglo XX , ya que todas las historias han sido contadas previamente; las narrativas contemporáneas más que producir nuevas historias buscan modos originales de narrar las mismas que, en definitiva, remiten a los clásicos. Como espectadores de la obra de Moffatt, y desde esta intertextualidad, se nos hace patente su conexión con narrativas, formatos y estéticas precedentes de amplia difusión universal, lo cual no significa en absoluto que su punto de vista, a la hora de narrar una historia o 
de formalizarla, no sea inequívocamente personal.
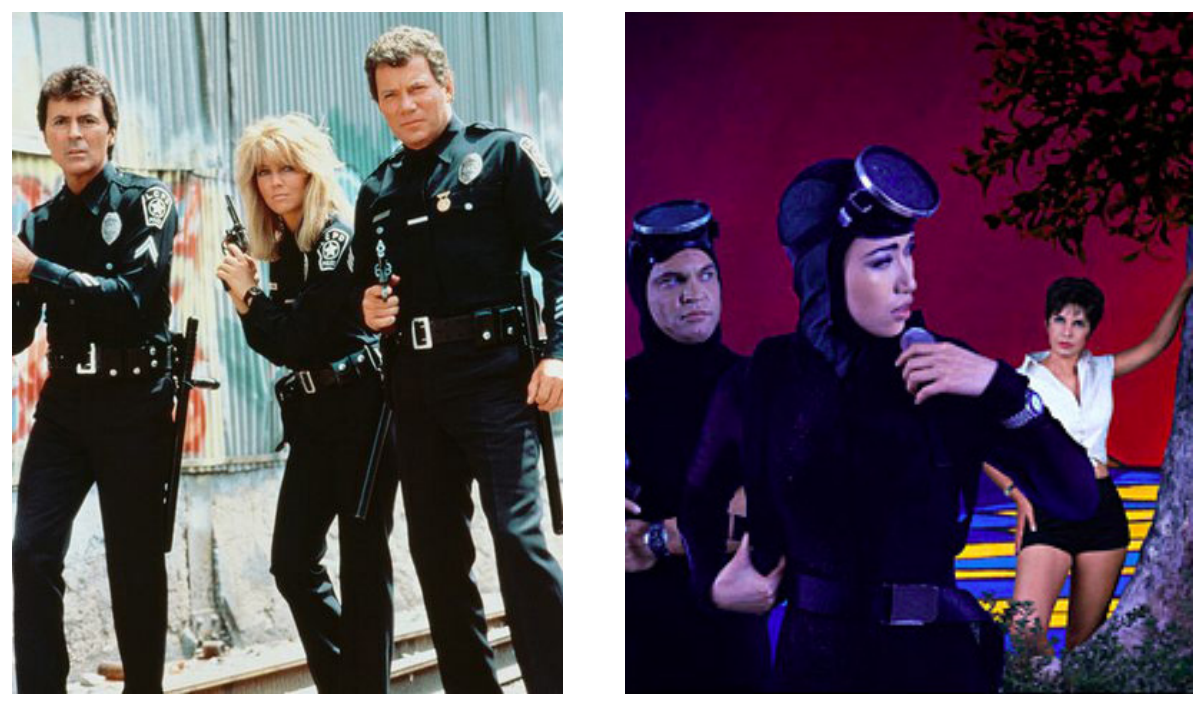

Figura 4. Serie "T.J. Hooker". 1982-1986. (C)

Figura 5. "Adventure Series" 4 (fragmento, autorretrato). (C)

Tracey Moffatt tiene una peculiar manera de definir el serial televisivo poniendo en relevancia ciertos factores los cuales veremos, de manera obvia, reflejados en su obra. Comenzaremos, por lo tanto, nuestro análisis textual de Adventure Series trascribiendo la conversación con Gerard Matt (1998-1999) en la que especifica los componentes de estos formatos que le atraen tanto.

Dramas televisivos americanos y australianos de bajo presupuesto donde el término "aventura" significaba saltar a una lancha motora o a un pequeño avión para atrapar a un ladrón y donde las historias suceden en lugares estupendos. [...] Respecto a la moda, la gente salía muy arreglada. Algunos personajes iban con uniforme de piloto o de guarda forestal, o con trajes de buceo, tanto hombres como mujeres daban la sensación de ser muy profesionales, como si estuvieran haciendo algo muy importante, pero al mismo tiempo se miraban con deseo (p. 92). 

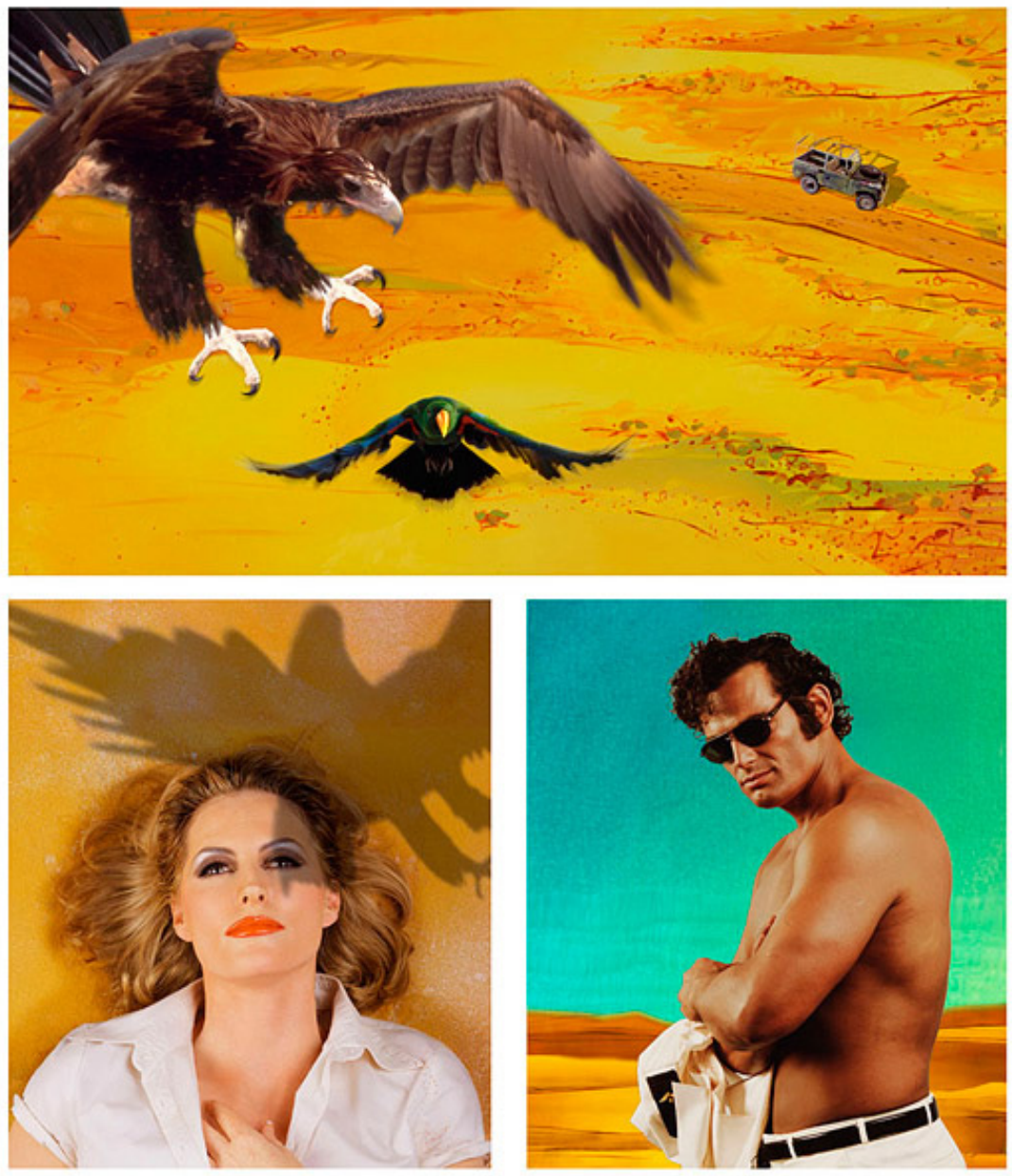

Figura 6. "Adventure Series" 3. (C)

Moffatt reconoce que le encantan los dramas televisivos americanos y australianos de bajo presupuesto, es más, en la nota de prensa que escribe para la inauguración de la exposición de Adventure Series en la galería Roslyn Oxley9 de Brisbane (Moffatt, 2004), especifica que la serie de la que se hace eco en esta obra es Los Rovers ${ }^{8}$ pero, además, Moffatt también menciona 
como referente el cómic Flying Doctor, tira cómica creada por John Dixon que aparece en el periódico australiano Perth's Weekend Mail en 1959. Este cómic viene al caso porque lo que comenzó siendo una tira cómica, fue adaptada al cine como Airhawk en 1981 (dirigida por David Baker), y más tarde en la serie televisiva The Flying Doctors que fue emitida en la cadena australiana Nine Network desde 1986 a 1984. Estas series están profundamente enraizadas en Australia, mostrando sus paisajes y obviando, por su carácter amable y aventurero, sus problemáticas raciales y colonialistas. Es la relación entre la memoria de hechos acontecidos en la cotidianeidad y la ficción televisiva que aportan estas series, la que se ve activada cuando Moffatt rompe las barreras entre realidad y ficción, enlazando lo visto en la pequeña pantalla con la realidad objetiva de su pasado ${ }^{9}$. En este sentido tenemos que destacar de manera especial el papel que ella misma desempeña en su obra Adventure Series como una de las protagonistas de la ficción que narra, más concretamente, tal y como lo reconoce a Susan Brigth (2005), como el de la "morena intensa" (p. 92). Moffatt se incluye en las aventuras televisivas, apropiándose de aquello que les da entidad como recuerdo, confiriéndole realidad a lo que es una imagen en la memoria.
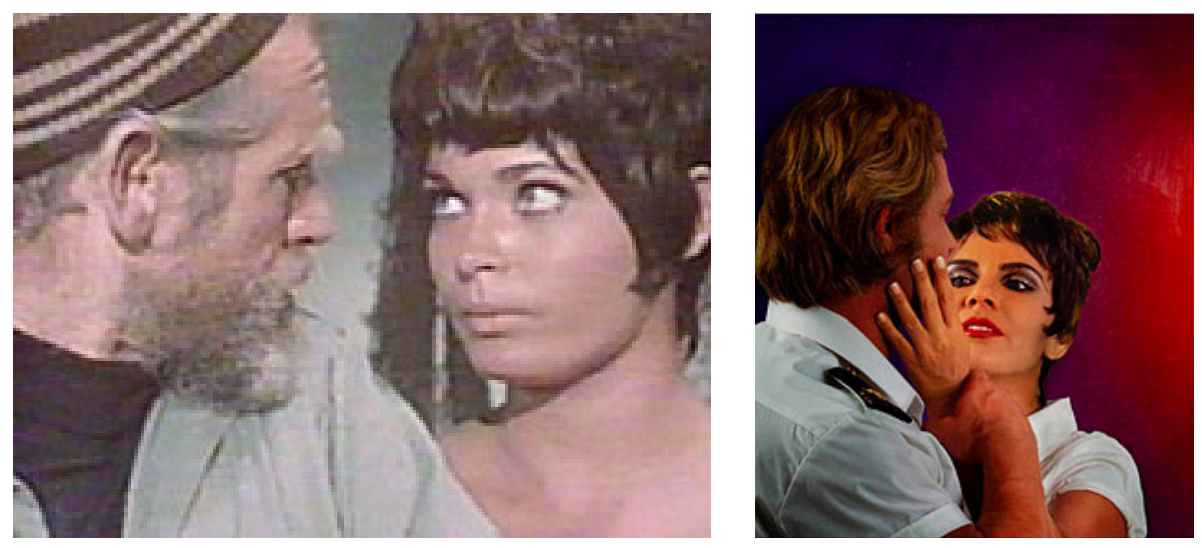

Figura 7. Serie "Los Rover", 1969-1970 (fotograma). (C)

Figura 8. "Adventure Series" 5 (detalle, autorretrato). (C) 
En cuanto a contenidos narrativos, nos gustaría dejar claro que el primer sustrato de cualquier narración, la fábula, está obligada a regirse por las leyes de la realidad sensible y cotidiana; pero, al no ser capaces de encontrar una fábula con una lógica temporal/espacial como base para la obra de Moffatt Adventure Series, deducimos que la autora solventa este condicionante convirtiendo el nivel fabular en una fuente de aquello que ejercerá como eje central del relato: el arquetipo. Efectivamente, Moffatt enumera a Bright (2005) todos y cada uno de los personajes que ha usado en Adventure Series: "Todos los personajes son prototipos, por ejemplo el prototipo de rubia, el del hombre moreno y atractivo, el de chica guapa y asiática, y el hombre tosco, acostumbrado a la vida al aire libre..." (p. 92). Es el personaje (figura primordial, mítica) el que detenta el mayor poder narrativo en la obra, aunque ninguno de estos personajes está vinculado a la acción, sino que están plenamente constituidos, como dice Barthes, "incluso antes de actuar". Esta anticipación, este saber ya de antemano los comportamientos y las relaciones, es lo que propicia en el espectador de Adventure Series la ilusión de relato: el relato está, incluso antes de su consecución.

Por lo tanto es, de manera indudable, la relación entre los arquetipos que desempeñan un papel en Adventure Series -y todo aquello que reportan: sus polaridades, determinaciones y ambigüedades- lo que soporta la historia desde el sustrato fabular y, de esta manera, la clásica diégesis se ve sustituida por la evocación de un universo estacionario, basado en un conflicto que no evoluciona sino es reproduciéndose a sí mismo -como decían Zunzunegui y Zubillaga (1988) sobre el conflicto entre los personajes Furillo y Fay de Hill Street Blues- y cuya suspensión transmite la idea de que nada tiene arreglo.

Aparte de los numerosos personajes, el uso del episodio apoya en Adventure Series otra característica de los seriales, la fragmentariedad narrativa. La obra de Moffatt necesita de las diez páginas que la componen para crear esa estructura en episodios y apropiarse así de la característica de repetición y multiplicación que poseen las series. Pero el hecho más importante es que el amplio contexto que despliegan estas diez páginas permite una descripción de la obra de modo puramente espacial, apoyando así el comportamiento estacionario de esa temporalidad. Refutamos de esta manera la suposición que hacíamos al principio del artículo de que las diez páginas de las que consta la obra no estuvieran vinculadas narrativamente a un proyecto global.

Frente a este relato se hace patente la necesidad de un lector/espectador determinado. La intertextualidad de Adventure Series y el reconocimiento que ésta promueve, provoca un acto evocativo, el cual realizará una mejor labor 
al espectador en el fracaso, o sea, cuando éste no consiga recordar bien y tenga que echar mano de aquellos elementos virtuales que permitan la fluidez evocativa $^{10}$. Así, las imágenes fotográficas en Adventure Series funcionan como resortes de una memoria que no concreta las situaciones, y como resultado de ello, los significados de cada elemento de la historia narrada no toman asiento fijo.

Para finalizar nos gustaría dejar claro que no sólo existen similitudes entre Adventure Series y el serial televisivo, sino que además esta obra saca provecho narrativo de todas esas afinidades estructurales y estéticas. Es dentro de la nube referencial en la que se ve envuelta esta obra, donde funciona como narración, sin que su estructura sintagmática necesite una traslación a estructuras lingüísticas ni, por supuesto, una decodificación bajo las normas morfosintácticas. Por lo tanto, confirmamos que el relato propuesto por Moffatt desde Adventure Series, gracias a las figuras primordiales, especulares del mito, que protagonizan su obra, a la intertextualidad a la que apela, y al tiempo en suspensión en el que se desarrolla, no sólo queda sujeta únicamente a sus propias indeterminaciones, sino que se desarrolla de forma narrativa y plástica gracias a ellas.

Como conclusión general constatamos que, la narratividad suspendida que forma parte del serial televisivo se adapta de manera particular a la imagen fotográfica secuenciada. Si el espectador ordena cada detalle de la obra -de tal manera que todo encaje en una historia que ya existe a priori como experiencia o memoria de ese mismo espectador-, el suceso que estos personajes protagonizan no estará únicamente sostenido por las imágenes fotográficas que componen formalmente la obra plástica, sino que terminan de surgir gracias al proceso de intertextualidad que se pone en marcha desde el espectador, a su memoria y a las relaciones que ésta desata. Si es el re-conocimiento, por parte del espectador, de las posibilidades argumentales que soporta el personaje arquetípico, lo que asegura la existencia de una historia, esta historia se reconocerá aunque no esté argumentalmente completa, no esté referida en un tiempo lógico/lingüístico y se constituya únicamente como evocación de una historia. Por lo que concluimos que la narración fotográfica secuencial es una nube de forma variable desvinculada semántica y sintácticamente de la arbitrariedad del orden lingüístico, libre de la esclavitud de sus estructuras y dotada de posibilidades argumentales que no atienden exclusivamente ni a la causalidad, ni a la temporalidad. Las herramientas narrativas son, de esta manera, una generosa y extraordinaria fuente de posibilidades para la imagen fotográfica. 


\section{Notas}

${ }^{1}$ Nos referimos al concepto de trama completa, compuesta por inicio nudo y desenlace, propuesto ya por Aristóteles (2009): "Todo (entero) es lo que tiene principio, medio y fin. Principio es lo que de suyo no es necesariamente después de otro: antes bien, después de sí exige naturalmente que otro exista o sea factible. Fin es al contrario lo que de suyo es naturalmente después de otro, y después de sí ningún otro admite. Medio lo que de suyo sigue a otro y tras de sí aguarda otro" (p. 25).

2 Wolfgang Iser y Hans Robert Jauss entre otros, plantean que la interacción entre el receptor y el texto, entre recepción y efecto, se da de forma dinámica; no en un sentido unidireccional, sino como un proceso dialéctico de construcción de sentido por medio de los interrogantes planteados por el lector al texto (Warning, 1989).

${ }^{3}$ Anna María Guasch (2003) nos aclara que "por Cultura visual o Estudios visuales entendemos un cambio fundamental en el estudio de la historia tradicional del arte en el que [...] el concepto de "historia" es sustituido por el de "cultura", y el de "arte" por lo "visual" jugando a la vez con la "virtualidad" implícita en lo visual y con la "materialidad" propia del termino cultura. En este sentido, la imagen es para los estudios visuales lo que el texto para el discurso crítico postestructuralista" (p. 8).

${ }^{4}$ En España se tradujo como Canción triste de Hill Street y fue exhibida entre 1986 y 1987.

5 El serial televisivo de mayor duración hasta el momento ha sido Guiding Light con 15.762 episodios desde su estreno el 30 de Junio de 1952 en televisión por la cadena americana CBS.

${ }^{6}$ Nos gustaría recordar aquí la gran variedad de tipos de identificación con el héroe de la narración existentes y que han sido catalogados por Jauss (1992). Estos son: Identificación asociativa, admirativa, simpatética, catártica e irónica.

${ }^{7}$ Queremos dejar claro que la intertextualidad es un concepto derivado del dialogismo que creó Mijail Bajtín (1986) Éste observó que los escritores responden en sus textos a textos literarios anteriores, siendo la obra un resultado de ese diálogo.

${ }^{8}$ Serie australiana de 39 episodios, en la cual un periodista, un fotógrafo de la fauna salvaje, el capitán de una goleta llamada Pacific Lady y su hijo, corren diferentes aventuras. Fue emitida originalmente en la televisión australiana durante los años 1969-70.

${ }^{9}$ Cabe destacar que Moffatt pertenece a lo que ha venido a llamarse The Lost Generation, generación de la cual forman parte más de 100.000 niños australianos de raza aborigen, que entre 1869 y 1976 sufrieron el secuestro por parte del gobierno australiano y su posterior "integración" dentro de familias blancas. De manera más o menos manifiesta, la obra casi al completo de Moffatt se hace eco de este hecho, de las costumbres colonialistas, del racismo encubierto y de la idílica cotidianeidad propuesta por los medios.

${ }^{10}$ Recordamos las teorías de las imágenes- recuerdo de Deleuze (2004): "no son la imagen recuerdo o el reconocimiento atento los que nos dan el justo correlato de la imagen ópticasonora, sino más bien los trastornos de la memoria y los fracasos del reconocimiento" (p. 80). 


\section{Referencias}

Aristóteles. (2009). El arte poética. Barcelona: El Cid Editor.

Baetens, J. (2009). Alrededor de la narración fotográfica: el ejemplo de la fotonovela. En F. Scianna y A. Ansón. (Eds.), Las palabras y las fotos.

Literatura y fotografia, (230-53). Madrid: Ministerio de Cultura.

Bajtín, M. (1986). Problemas de la poética de Dovstoievski. México: FCE.

Barthes, R. (1977). Introducción al análisis estructural de los relatos.

Buenos Aires, Argentina: Centro Editor de America Latina.

Bright, S. (2005). Fotografia Hoy. Donosti: Nerea.

Curiel, F. (2001). Fotonovela rosa, fotonovela roja. México: Textos de difusión cultural Unam.

De Lizaur, B. (1995). La telenovela como literatura popular. Anthropos.

Revista de documentación Científica De la Cultura, 166-167, 133-35.

Deleuze, G. (2004). La imagen-tiempo. Estudios sobre cine 2. Barcelona:

Paidós.

Guasch, A. M. (2003). Los Estudios Visuales. Un estado de la cuestión.

Estudios Visuales, 1, 8-16.

Jauss, H. R. (1992). Experiencia estética y hermenéutica literaria. Madrid:

Taurus.

Kristeva, J. (1978). La palabra, el diálogo y la novela. En: Semiótica I (187-

225). Madrid: Fundamento.

Matt, G. (1998). Tracey Moffat- Gerard Matt: una conversación. Arte y Parte, 18, 8-17.

Menéndez Menéndez, M. I. (2008). Discursos de ficción y construcción de la identidad de género en televisión. Palma: Universidad de las Islas Baleares.

Moffatt, T. (2008). The Story of Tracey Moffatt's Adventure Series Photo Shoot in Brisbane. Nota de prensa de la exposición de Adventure Series. Galería Roslyn Oxley9. Recuperado de: http://www.roslynoxley9.com. au/news/releases/2004/07/09/75/

Rojas Rojas, R. \& Cruz Soto, R. (s/f). La fotonovela en México.

Comunicación e Ideología, 4, 39-79.

Tous, A. (2010). La era del drama en televisión. Perdidos, CSI: Las Vegas,

El ala oeste de la Casa Blanca, Mujeres desesperadas y House.

Barcelona: UOCpress.

Warning, R. (ed.). (1989) Estética de la Recepción. Madrid: Visor. 
88

$$
\text { María Caro - Adventure Series de Tracey Moffatt }
$$

Zunzunegui, S. \& Zubillaga, J. (1988). Tengan mucho cuidado ahí dentro. "Hill Street Blues" o los variados matices del gris. Valencia: Centro de Semiótica y Teoría del Espectáculo.

María V. Caro Cabrera: Profesora de la Facultad de Ciencias de la Educación. Universidad de Málaga.

Contact Address: Facultad de ciencias de la Educación. Bulevar Louis Pasteur, 25. Campus de Teatinos. 29010 Málaga.

E-mail address: carocabrera.maria@gmail.es 
Instructions for authors, subscriptions and further details:

http://brac.hipatiapress.com

\section{Mathias Goeritz. Recuerdos de España, 1940-1953}

\section{Alberto Castán Chocarro ${ }^{1}$}

1) Universidad de Zaragoza. España

Date of publication: February $3^{\text {rd }}, 2015$

Edition period: February 2015 - June 2015

To cite this article: Castán, A., (2014). Mathias Goeritz. Recuerdos de España, 1940-1953. [Review of the book]. Barcelona, Research, Art, Creation, 3(1), 89-91. doi: 10.4471/brac.2015.06

To link this article: http://dx.doi.org/10.447/brac.2015.06

\section{PLEASE SCROLL DOWN FOR ARTICLE}

The terms and conditions of use, except where otherwise noted, are related to the Open Journal System and to Creative Commons Attribution License (CCBY). The indication must be expressly stated when necessary. 
BRAC - Barcelona Research Art Creation. Vol. 3 No. 1, February 2015, pp. 89-91

\section{Reviews (I)}

Tudelilla Laguardia, Chus. (2014). Mathias Goeritz. Recuerdos de España, 1940-1953. Zaragoza: Prensas de la Universidad de Zaragoza. ISBN 978-84-16028-26-9

Mathias Goeritz: trabajador del arte vivo.

Mathias sembró la fe en los corazones en unos momentos en que el arte vivo luchaba en España entre la vida y la muerte. Mathias le dio nuevo ser. Le infundió vida y calor. Sus incansables campañas en pro del arte nuevo, sus ediciones, sus exposiciones, prepararon el advenimiento de la Escuela de Altamira, cuantioso patrimonio ausente que unos hombres de buena voluntad, unos críticos y artistas de tendencias afines, hemos heredado, proponiéndonos cuidar de su permanencia y aumentarlo ( $\mathrm{p}$. 204).

Con estas palabras, -incluidas en el libro Homenaje a Mathias Goeritz coordinado por el poeta Carlos Edmundo de Ory-, se refirió Sebastián Gasch a la inestimable contribución realizada por Mathias Goeritz al llamado proceso de normalización de la cultura española durante la posguerra. Este, y otros muchos testimonios recogidos y analizados por Chus Tudelilla, construyen el libro Mathias Goeritz. Recuerdos de España, 1940-1953; resultado de la tesis doctoral que la autora dedicó a una figura clave, tantas veces referenciada como escasamente estudiada, de la cultura artística española durante la década de 1940.

Mathias Goeritz se instaló en España en 1945, beneficiándose, apunta Chus Tudelilla, del aislamiento internacional en que se encontraba el país; justo 
cuando su vinculación con diferentes instancias oficiales de la Alemania nazi podían suponer un problema que, no obstante, supo solventar. Fue entonces cuando comenzó su renacimiento: Goeritz puso en marcha un cuidadoso juego de apariencias para reinventarse ante quien estuviera dispuesto a escuchar. Todo un personaje de novela, cabría decir, si no fuera porque el relato de Chus Tudelilla se asienta en la más estricta investigación, sin lugar para fabulaciones.

En 1946 Goeritz se presentó al público español como un pintor moderno. Y lo hizo en la galería Clan de Madrid, dirigida por Tomás Seral y Casas. Allí inició fructíferas conexiones que le permitieron, en apenas tres años entre 1947, cuando se instaló en Madrid tras su paso por Granada, y 1949, cuando partió hacia México-, aglutinar los anhelos de quienes, recuerda Tudelilla, habían quedado aislados entre sí tras la Guerra Civil. Y ponerlos en contacto con una nueva generación. Chus Tudelilla, a través de Goeritz, contribuye al conocimiento de la realidad cultural de la España del momento, completando el estudio de autores como Ángel Ferrant, Benjamín Palencia, Ricardo Gullón, José Llorens Artigas, Pablo Beltrán de Heredia, Sebastián Gasch, Rafael Santos Torroella, Eduardo Westerdahl, Eugenio d'Ors, Carlos Edmundo de Ory, los pintores del grupo Pórtico de Zaragoza -Aguayo, Lagunas y Laguardia-, o Antonio Saura. Mathias Goeritz, sostiene Tudelilla, "lo aprendió todo de Ángel Ferrant sin que este apenas se diera cuenta de lo mucho que le estaba enseñando" (p. 11). Ferrant fue para Goeritz la "varita mágica" -afirmó Llorens Artigas-, que le permitió articular una compleja red de conexiones que estableció, en primera instancia, a través de una insistente relación epistolar como testimonia esta publicación.

"Creo que su paso por España será algo parecido al diluvio" (p. 159), le escribió Eduardo Westerdahl cuando el Plan de Altamira concebido por Goeritz estaba a punto de hacerse realidad; aunque Goeritz no pudo participar de la primera reunión de la Escuela. Precisamente en Santillana del Mar, durante el verano de 1948, Goeritz estrechó los contactos que le permitirían viajar a Guadalajara, Jalisco, como profesor de la Escuela de Arquitectura. Y allí llegó en octubre de 1949. No cesó en su incansable actividad y, como señala Chus Tudelilla, le bastaron dos meses para transformar por completo el panorama cultural de la ciudad mexicana. En su maleta, continúa la autora de este libro, atesoraba la experiencia española, de la que se alimentó en los proyectos que puso en marcha al menos hasta 1953, fecha límite de su investigación.

La monografía de Chus Tudelilla supone, desde ya, una lectura obligada entre los estudios dedicados a la vida artística y cultural española de la 
década de 1940. Contribuye a deshacer errores reiterados por la historiografía precedente como el relativo a la numeración y edición de la colección de Artistas Nuevos, amplía datos sobre la Escuela de Altamira, profundiza en las estrechas relaciones de Goeritz con quienes se quedaron en España, y nos deja a la espera de nuevas aportaciones que contribuyan a desenmarañar los proyectos de tan sugerente "tribu", al decir de Westerdahl. Una "tribu" intergeneracional a cuyo dinamismo contribuyó decisivamente Mathias Goeritz.

Alberto Castán Chocarro

Universidad de Zaragoza. España

alcastan@unizar.es 
Instructions for authors, subscriptions and further details:

http://brac.hipatiapress.com

\section{List of Reviewers}

Date of publication: February $3^{\text {rd }}, 2015$

To cite this article: (2015). List of Reviewers. Barcelona, Research, Art, Creation, 3(1), 92. doi: 10.4471/brac.2015.07

To link this article: http://dx.doi.org/10.447/brac.2015.07

\section{PLEASE SCROLL DOWN FOR ARTICLE}

The terms and conditions of use, except where otherwise noted, are related to the Open Journal System and to Creative Commons Attribution License (CCBY). The indication must be expressly stated when necessary. 
BRAC - Barcelona Research Art Creation. Vol. 3 No. 1, February 2015, p. 92

\title{
List of Reviewers
}

The editors of the Barcelona Research Art Creation, we wish thank the reviewers for their contributions to the quality of the journal during 2014 .

\author{
Àlex Nogué \\ Joan Descarga \\ Miquel Planas \\ Editors
}
Albrand, Alexandra
Montoya, Josep
Alonso, Inmaculada
Negre, Marta
Baigorri, Laura
Pastor, Jesús
Cabré, Víctor
Puig, Eloi
Cantalozella, Joaquim
Quintana, Angel
Daumal, Francesc
Rabinovich, Silvana
Egea, Jorge
Reverter, Ferran
Granell, Francesc
Serra, David
Jori, Josep $\mathrm{M}^{\mathrm{a}}$
Soler, Paz
Labastida, Ignasi
Vallmitjana, Santiago
Manzano, Daniel
Vaz, Oriol

Monterde, José Enrique 